\title{
التناص القرآني في الخطاب النقدي لمارون عبود
}

\author{
The Qur'anic intertextuality in Maroun Abboud's critical discourse
}

تاريخ الاستلام : 2019/10/08 ؛ تاريخ القبول : 2021/03/17

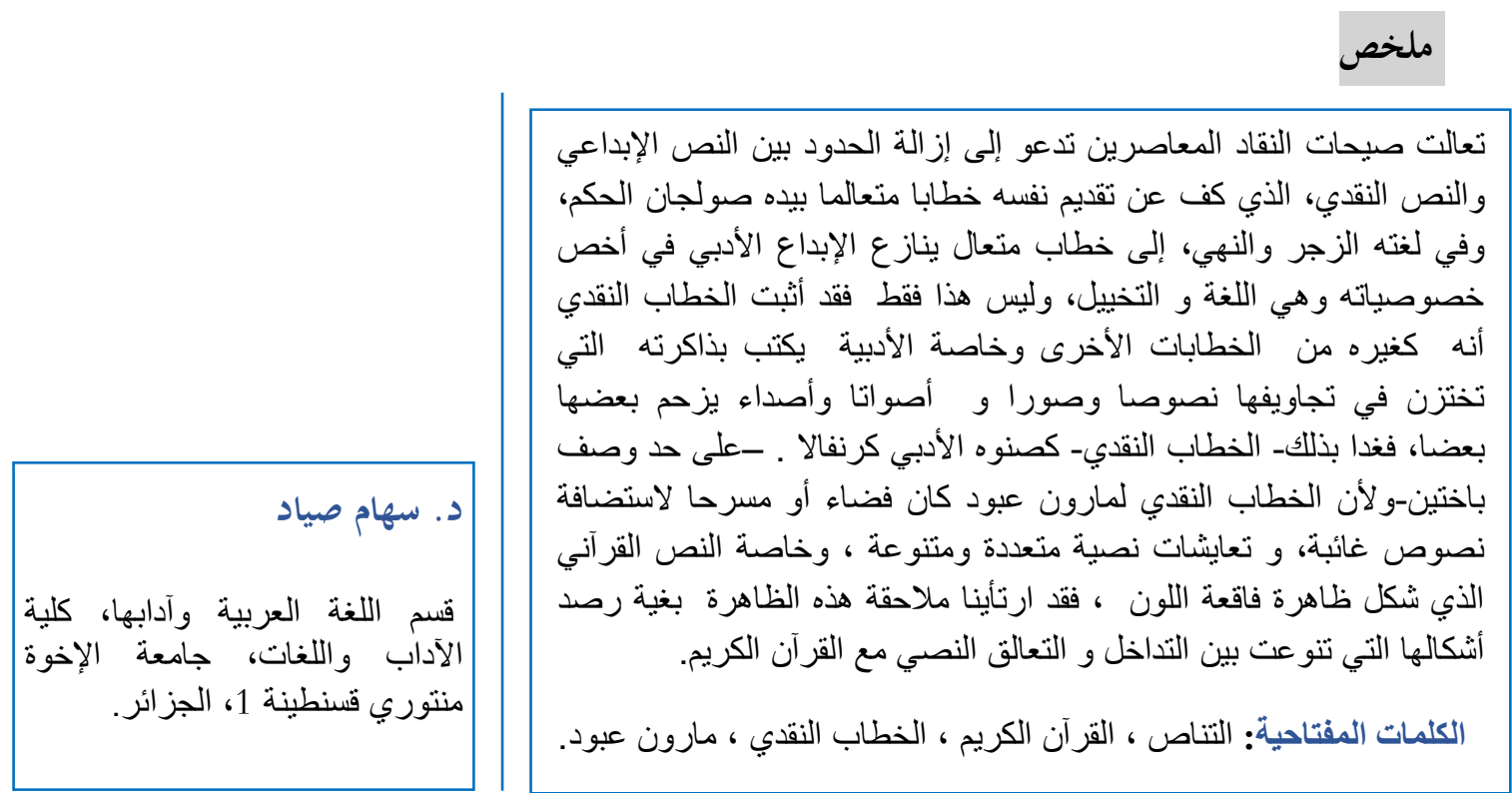

\section{Abstract}

The screams of modern criticism call for the removal of the boundaries between the creative text and the critical text. This latter has ceased to present itself with a discourse that dominates the scepter of power and has a denial in his language, to a transcendent discourse that defies the literary creativity in its peculiarities and that is language and fiction. The critical discourse has proved that it is like all the other discourses, especially the literary ones because it writes with its memory that memorizes texts, images, voices and echoes piled together.However, the critical discourse has become like a carnival as described by Bakhtin and because MarounAbboud's critical discourse was a space or a theater for accommodating absent texts and a diverse textual coexistence, especially the Qur'anic text, which was a colorful phenomenon. We considered pursuing this phenomenon by criticizing MarounAbboud for observing these forms, which varied between interaction and textual transcendence with the Qur'an.

Keywords: Intertextuality, Quran, Critical discourse, Maroun Abboud.

\section{Résumé}

Les cris de la critique moderne appellent à la suppression des limites entre le texte créateur et le texte critique. Ce dernier a cessé de se présenter avec un discours qui domine le sceptre du pouvoir et possède du déni dans son langage, à un discours transcendant qui défie la créativité littéraire dans ses particularités et c'est le langage et la fiction. Le discours critique a prouvé, qu'il est comme tous les autres discours, notamment littéraires car il écrit avec sa mémoire qui mémorise des textes, des images, des voix et des échos entassés ensemble. Cependant, le discours critique est devenu comme un carnaval comme décrit par Bakhtine - et parce que le discours critique de MarounAbboud était un espace ou un théâtre pour accueillir des textes absents et une coexistence textuelle diverse, en particulier le texte coranique, qui était un phénomène de couleur. Nous avons envisagé de poursuivre ce phénomène en critiquant Maroun Abboud afin d'observer ces formes, qui variaient entre l'interaction et la transcendance textuelle avec le Coran. Maroun Abboud.
Mots clés: Intertextualité, Coran, Discours critique,

* Corresponding author, e-mail: mahdi.mechta@umc.edu.dz 
يشكل ارتحال الأنساق الثقافية عبر الأزمنة و عبر النصوص الإبداعية؛ هذه الأنساق

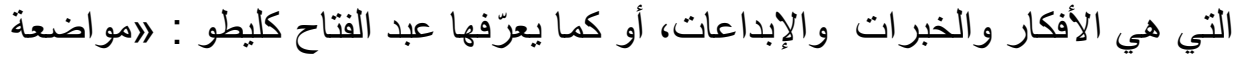

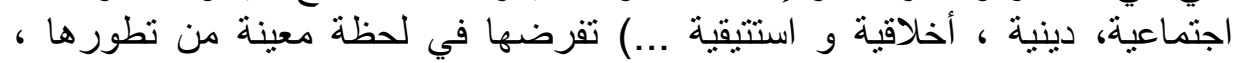

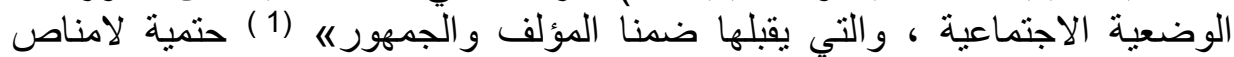

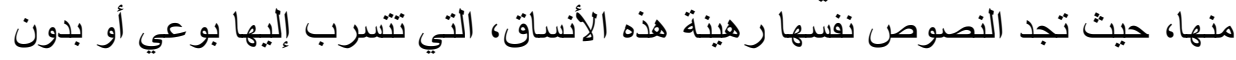

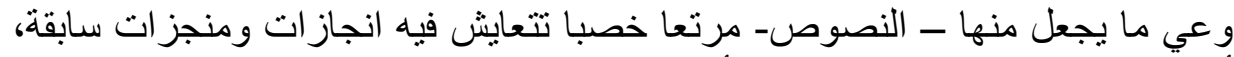

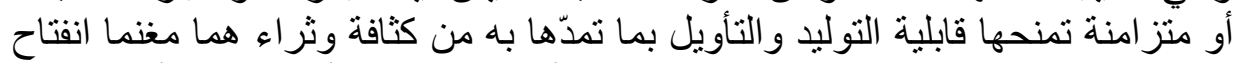

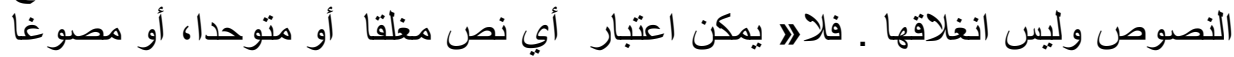

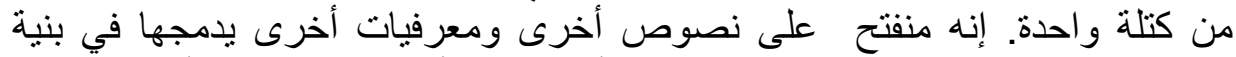

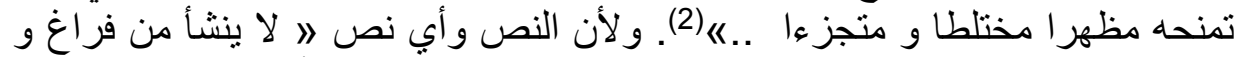

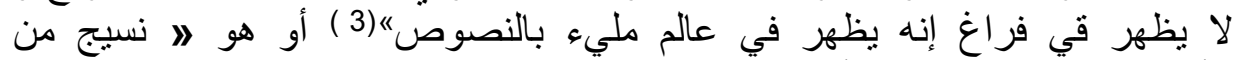

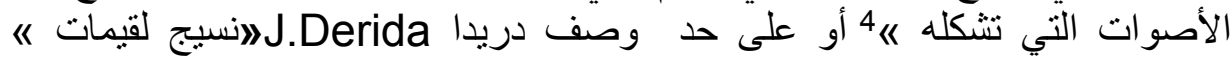

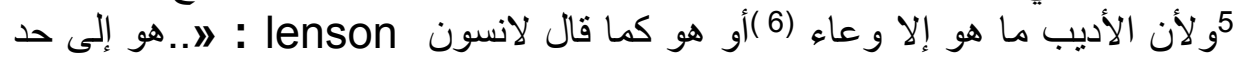

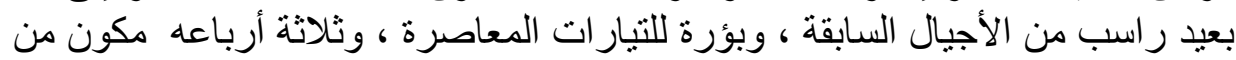

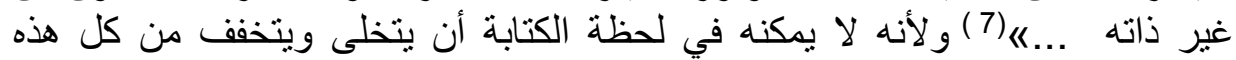

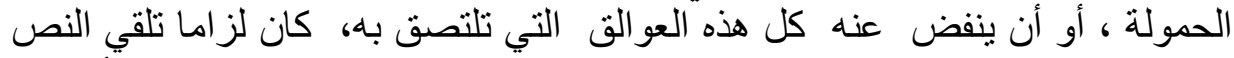

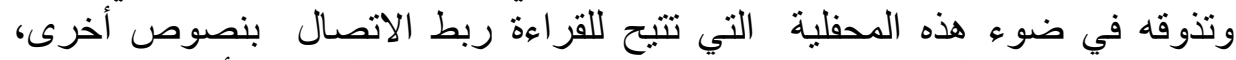

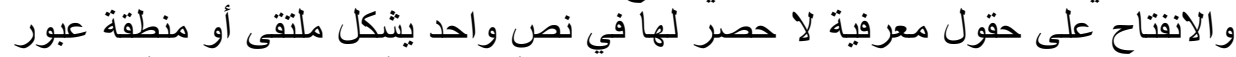

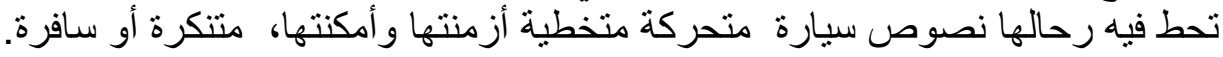

و بعتبر الناقد الروسي شكلوفسكي chklovski هو أول من تتبه(8) إلى عملية

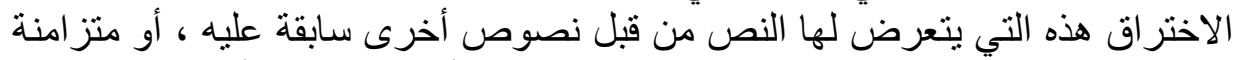

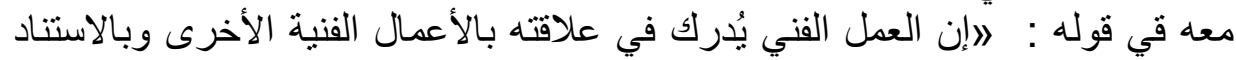

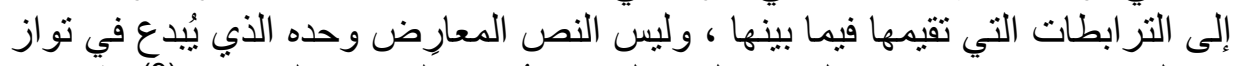

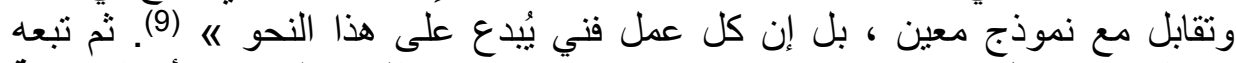

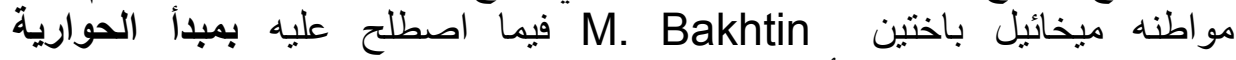
dialogisme

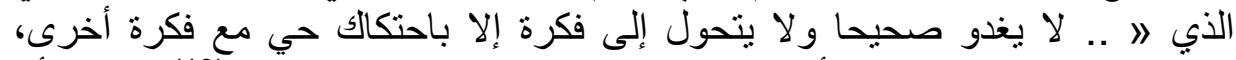

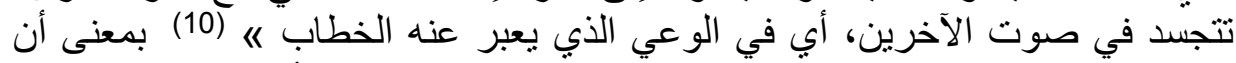

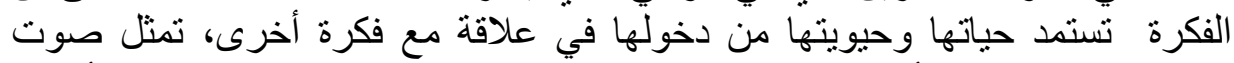

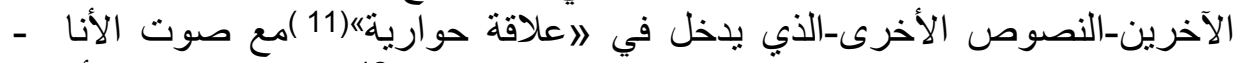

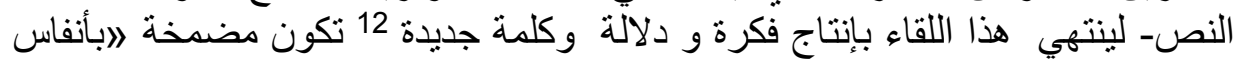

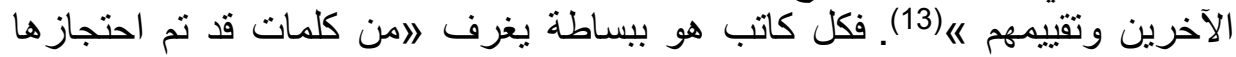

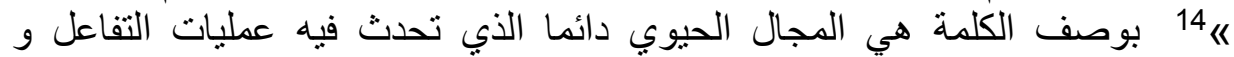

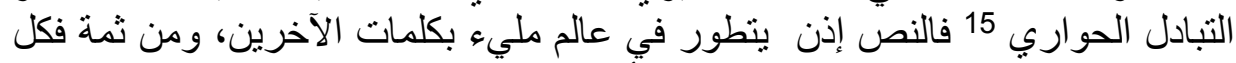

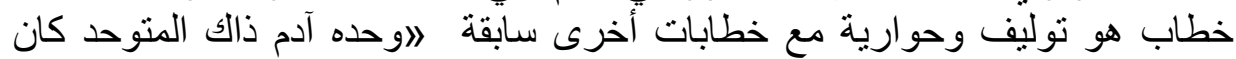

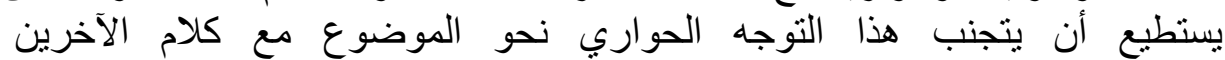

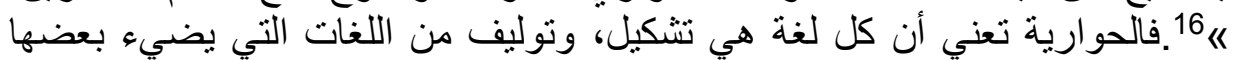

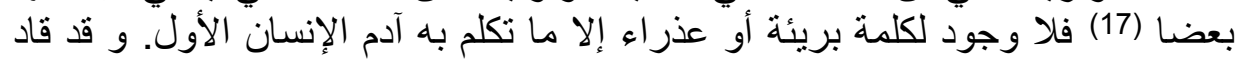

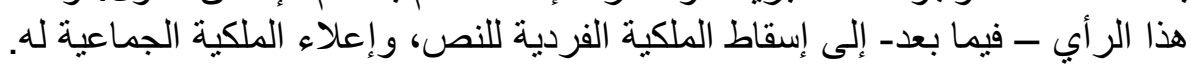

وتتو الى محاولات إنضاج وبلورة فكرة الحوارية الباختينية التي ستتجاذبها

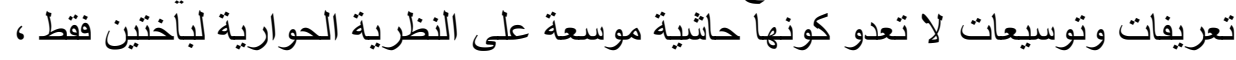

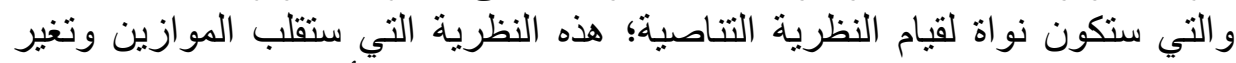

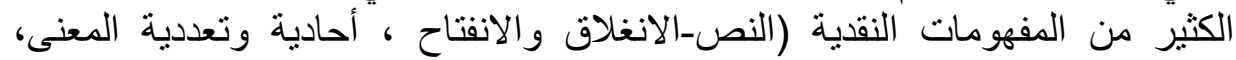

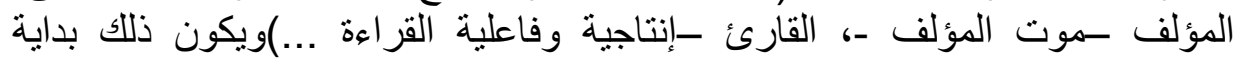
بالناقدة البلغارية جوليا كريستيفا Kristeva التي يعزى إليها الفضل في إطلاق 


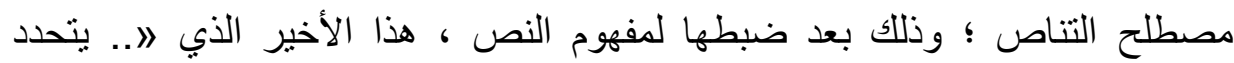

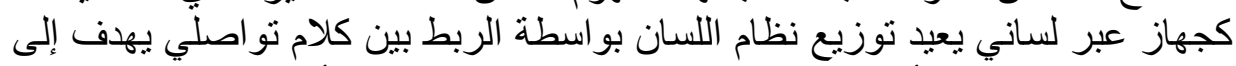

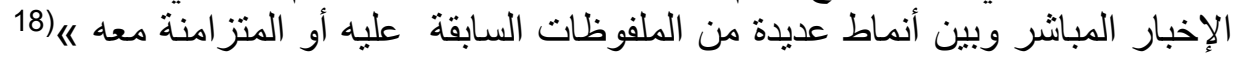

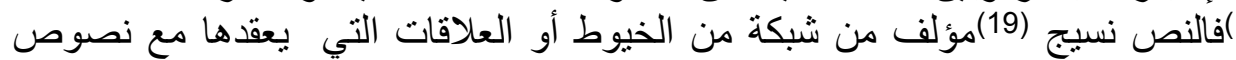

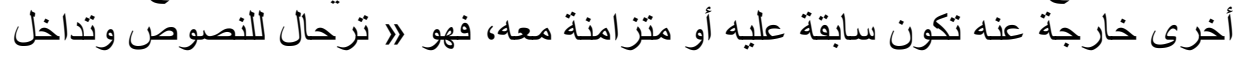

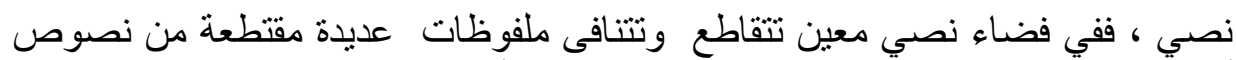

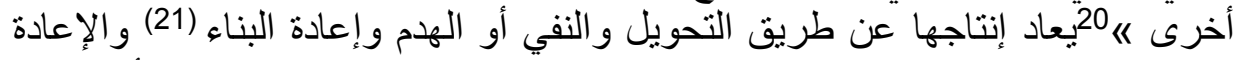

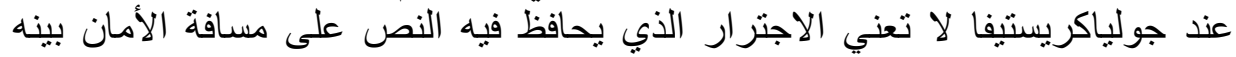

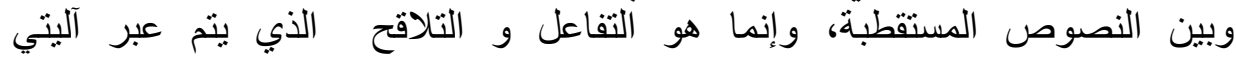

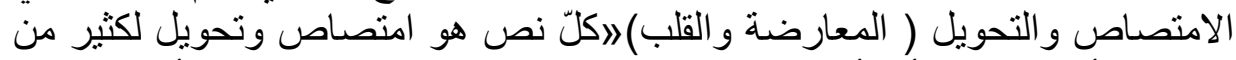

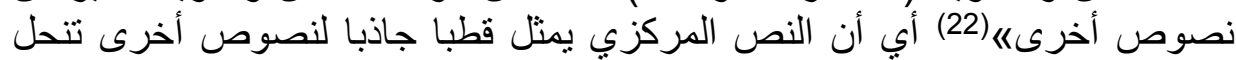

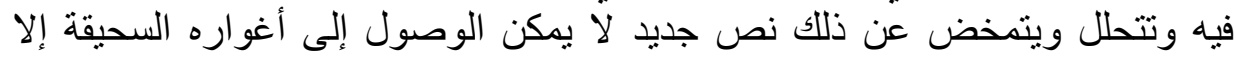

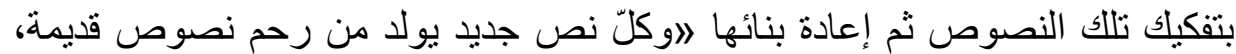

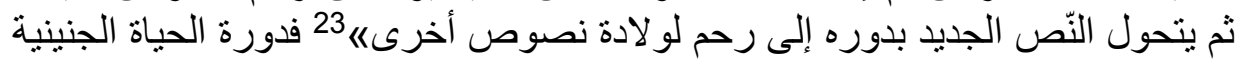

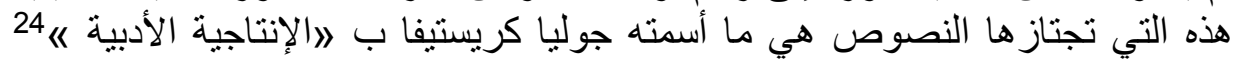

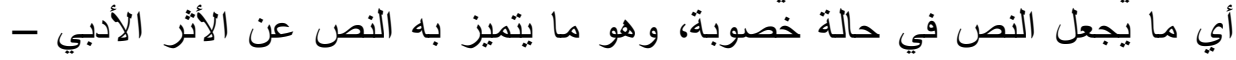

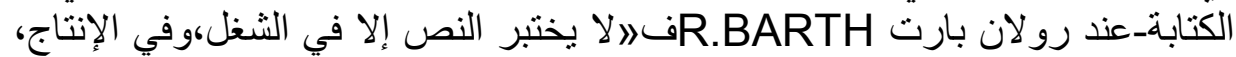

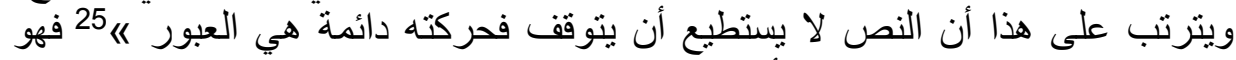

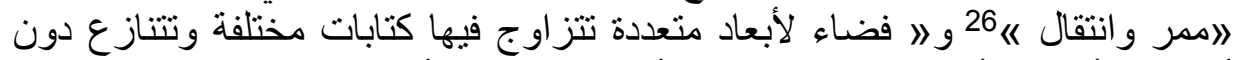

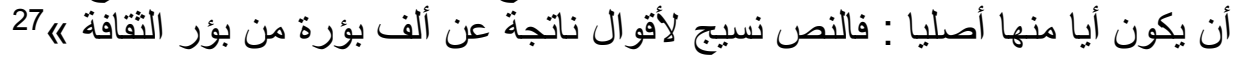

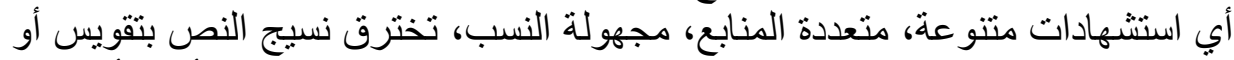

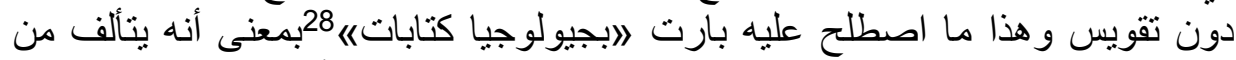

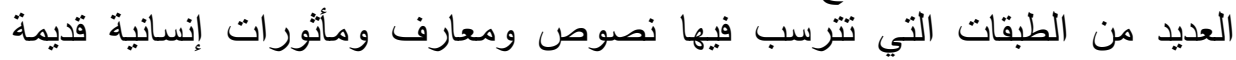

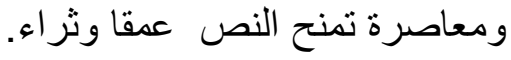

والملاحظ أن عبارة بارت السابقة تسلط الضوء على فعل التلقي وفاعلية القراءة التهاء

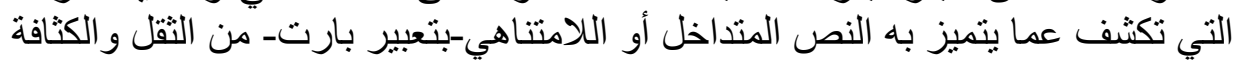

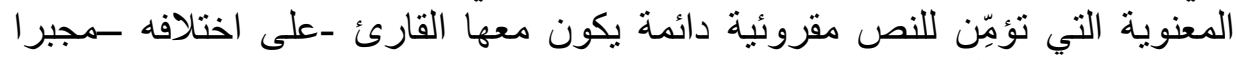

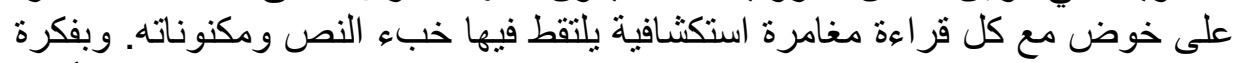

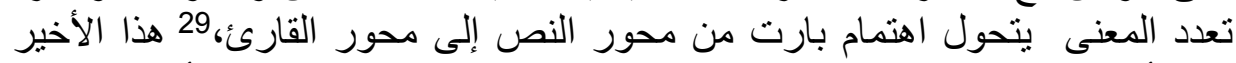

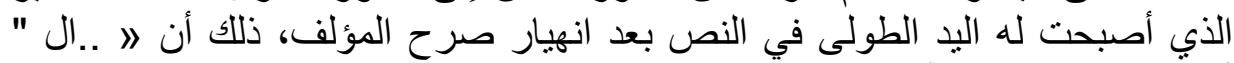

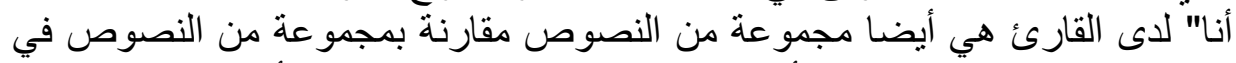

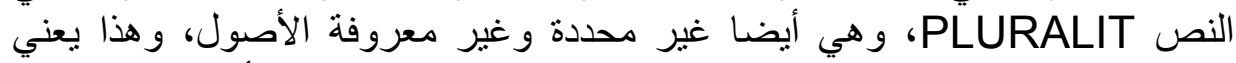

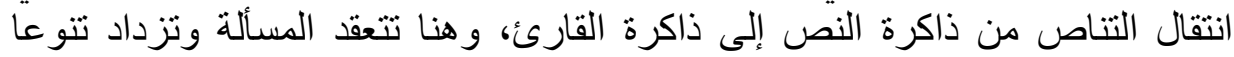

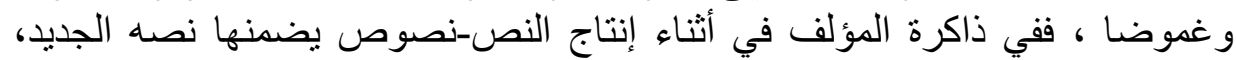

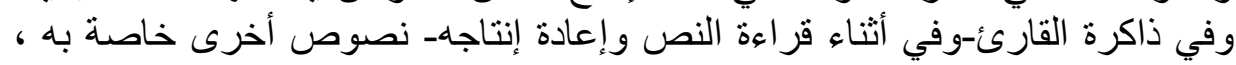

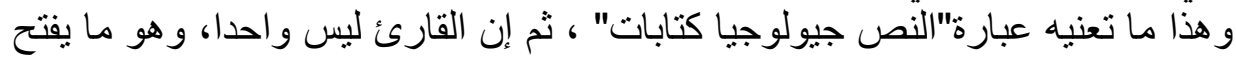

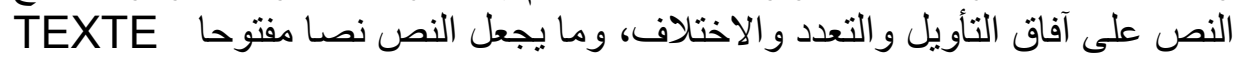

(30)OUVERT

فالقارئ كما وصف نفسه رولان بارت أثبه شيء بمكان عام أو سوق بضم أناسا

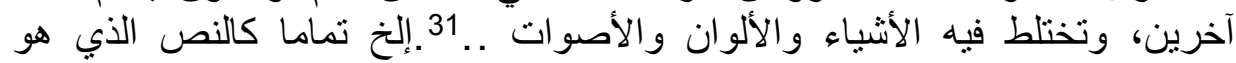

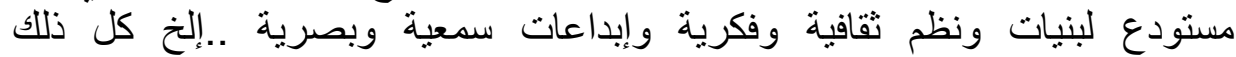

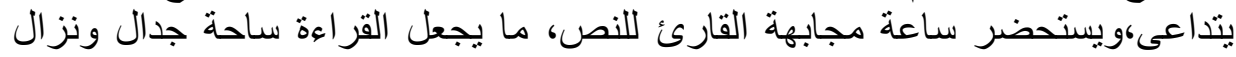

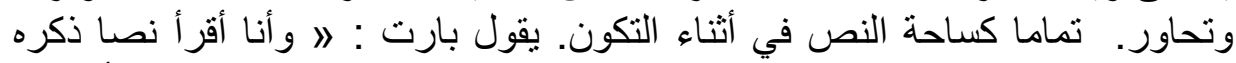

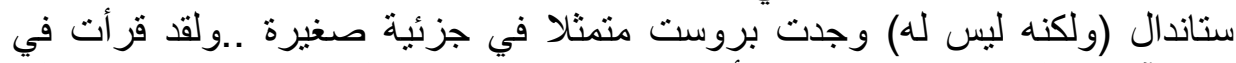

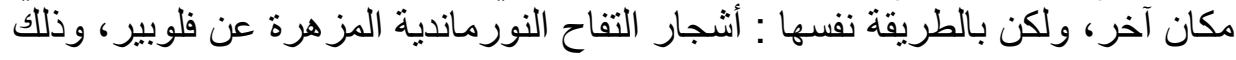




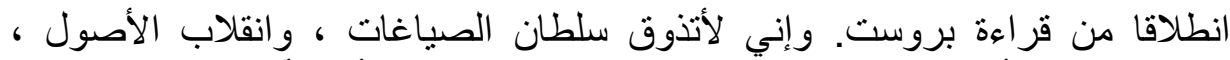

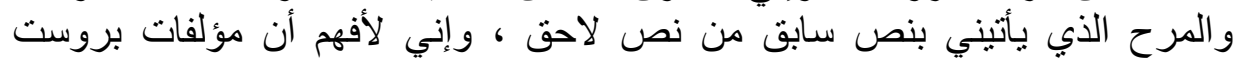

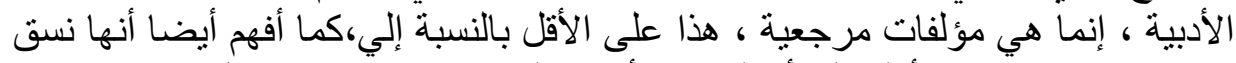

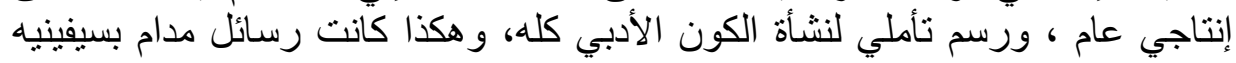

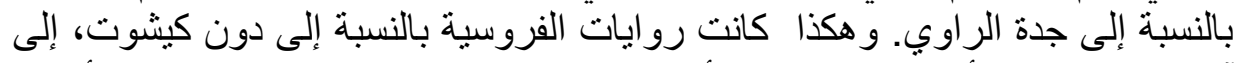

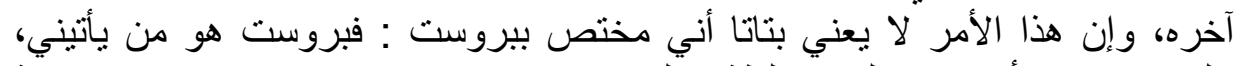

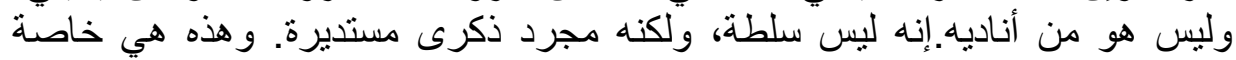

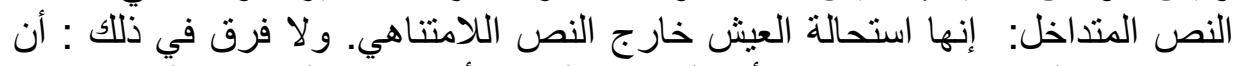

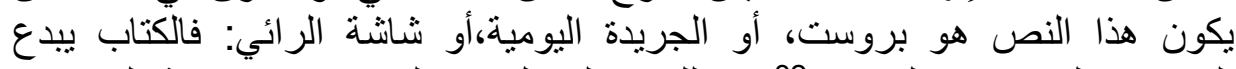

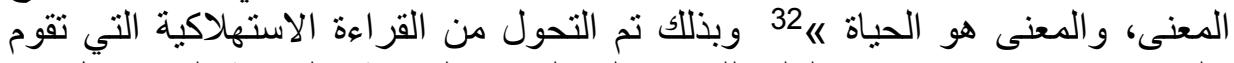

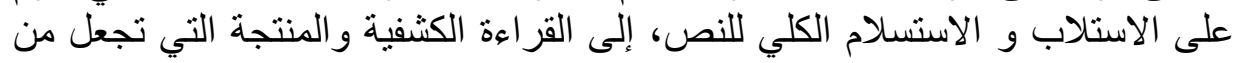

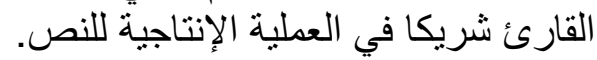

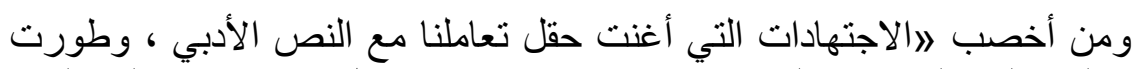

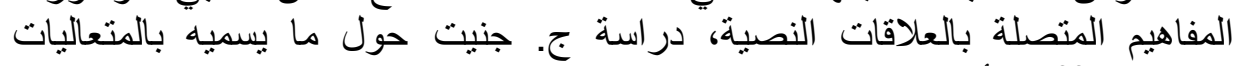

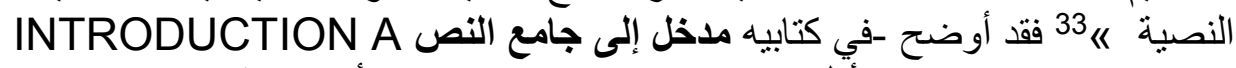
LRCHITEXTE

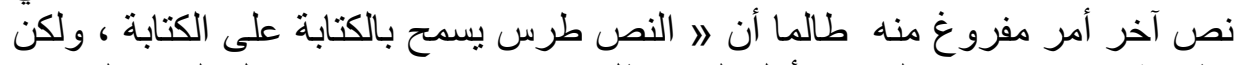

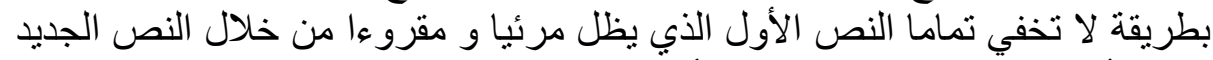

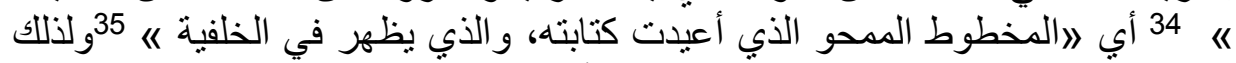

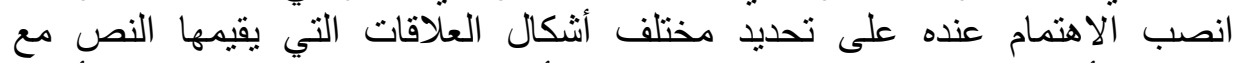

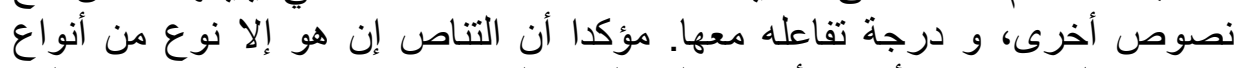

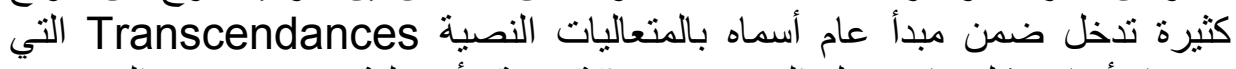

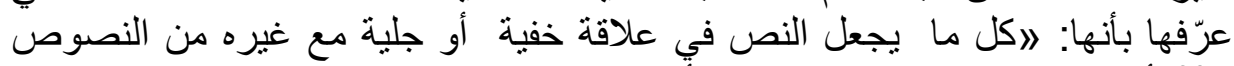

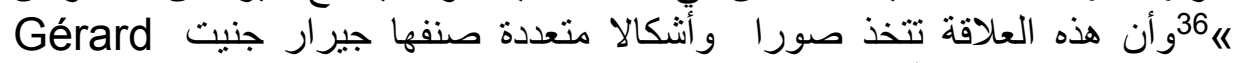
Genette

1- التناص أو أو التداخل النصي -كما حدنه-كرستيفا ويعني التواجد اللغوي لنص في نص آخر ، ومن أنماطه الاستشهاد ، و والسرقة ، ودنه ، والتضمين.

2-المناص Paratextualité : ويشمل كل ما يدخل فيما يسميه جنيت بالعتبات النصية ويتمثل فيما يعرض على الغلاف الخارجي(العنوان و العنوان الفرعي الصنور

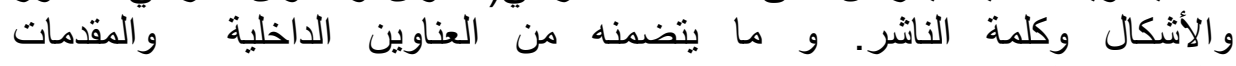
و والهو امش..إلخ.

3- الميتناص Métatextualité حيث يرتبط نص بآخر بعلاقة التفسير والتعليق دون ذكره.

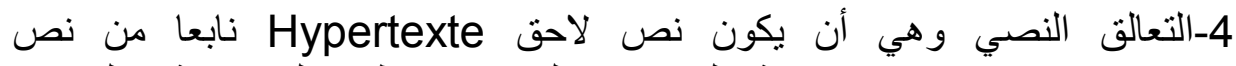
سابقHypotexte وهي علاقي أنة المحاكاة و التغيير وتعطينا المعارضة و والمحاكاة الساخرة فكرة عنها.

5-جامع النص Architextualité : و هي اقتران نص بمختلف أنماط الخطاب التي ينتمي إليها النص، وهي علاقة ضمنية صنامتة 37 .

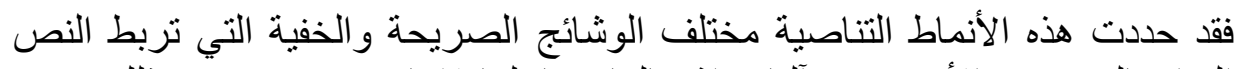

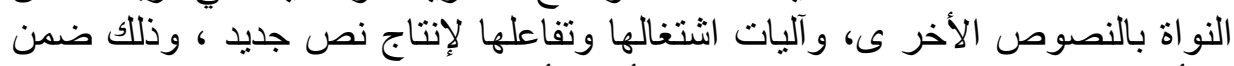

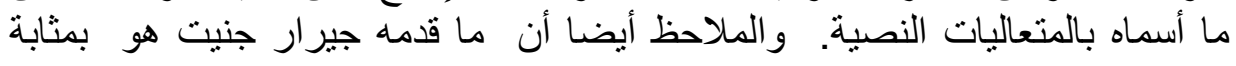




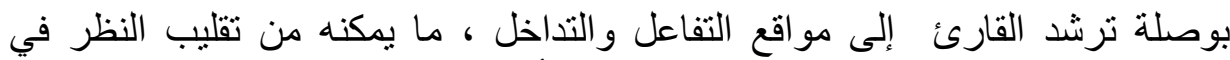

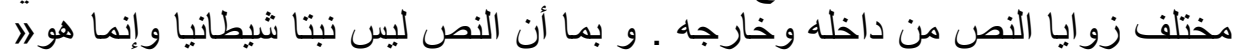

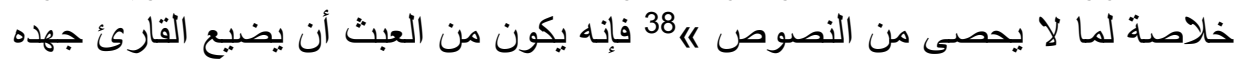

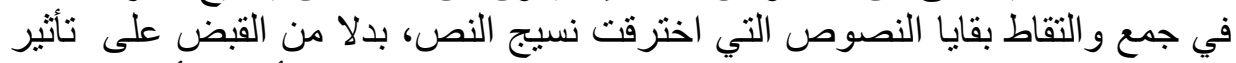
هذا الاختراق ودلالاته وفك شيفراته، وهذا لايتحقق إلا بما أسماه أمبرتو إيكو هـ

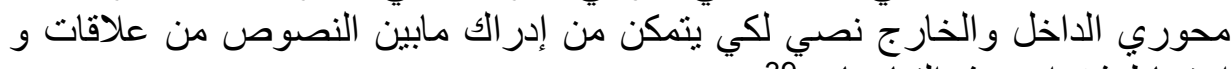
استتباط شفر ات هذه التناصات

ولأن متابعة تمدد وتوسع النظرية التناصية عند أبرز الأسماء النقدية الغربية

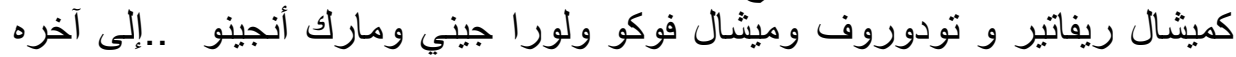

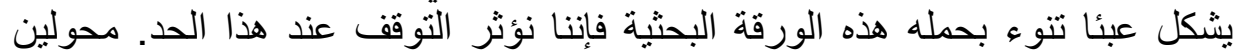

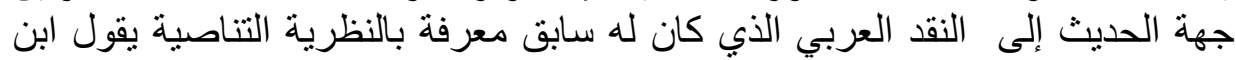

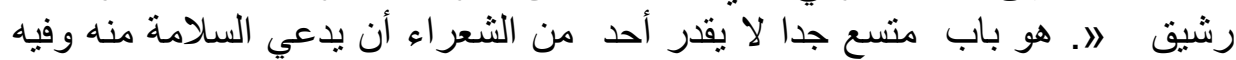

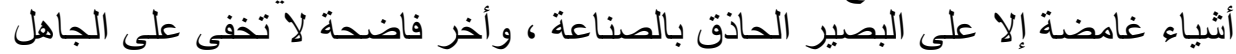

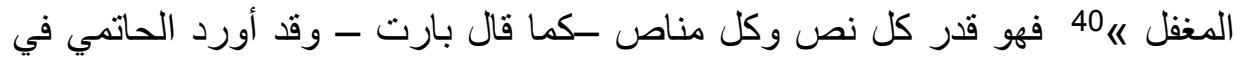

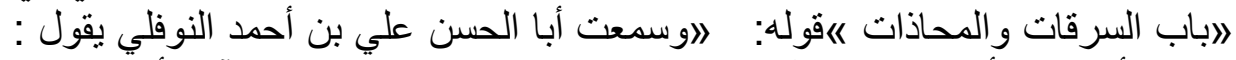

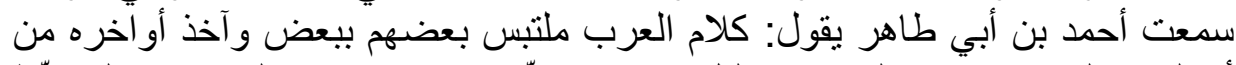

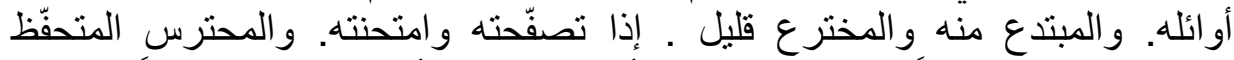

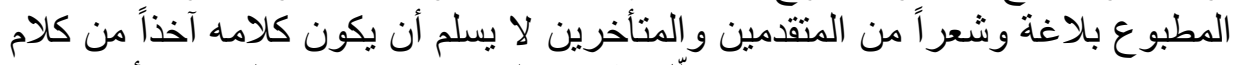

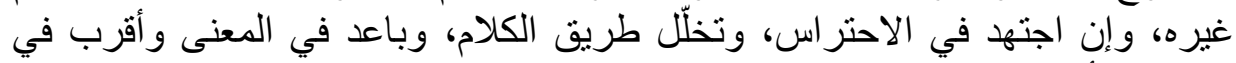

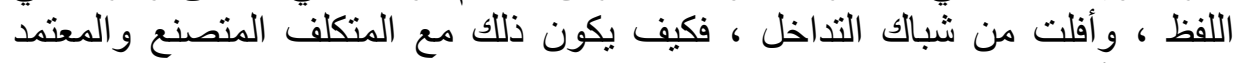

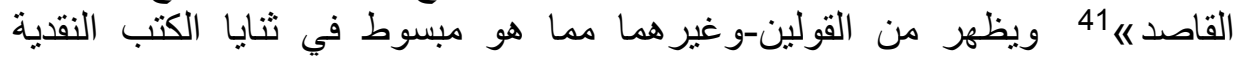

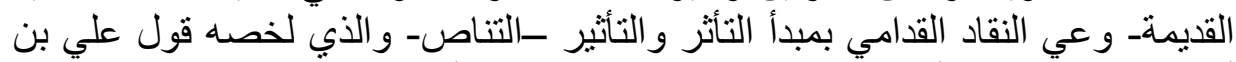

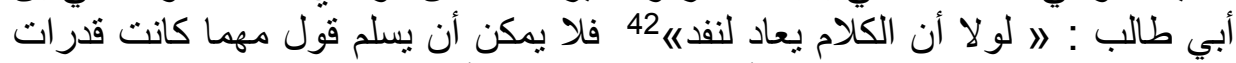

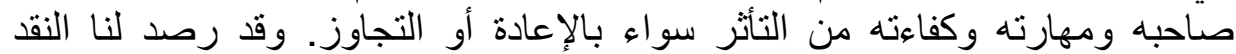

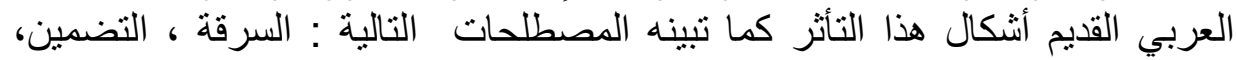

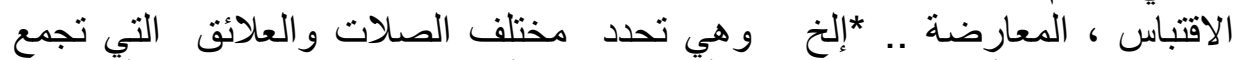

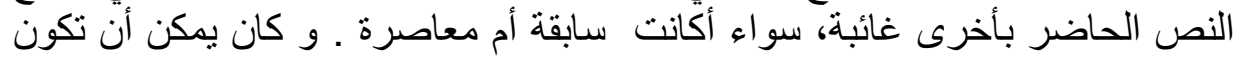

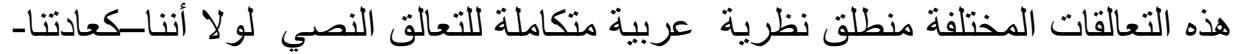

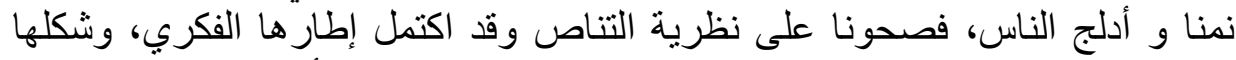

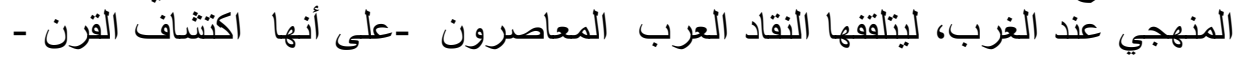

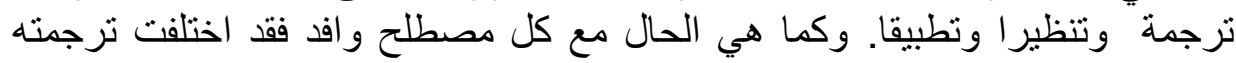

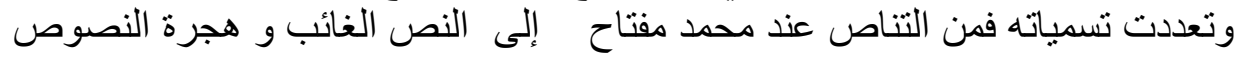

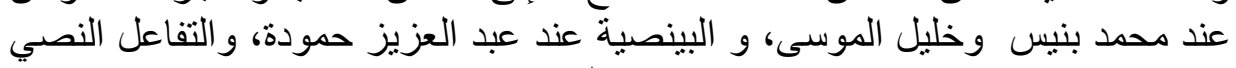
عند سعيد يقطين، و التداخل النصي عند عبدالله الغذامي ....إلخ.

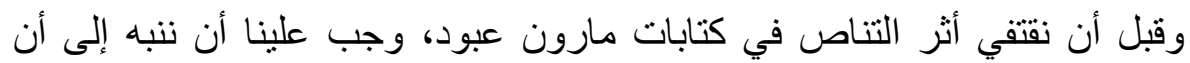

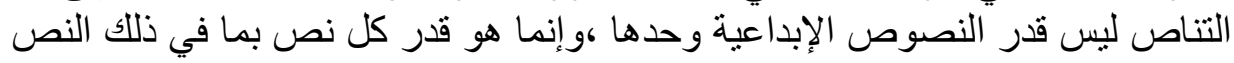

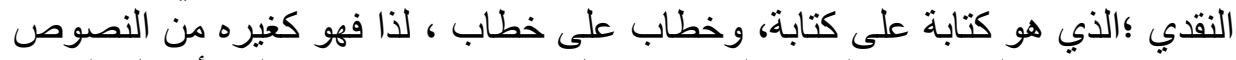

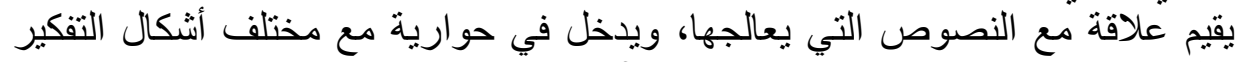

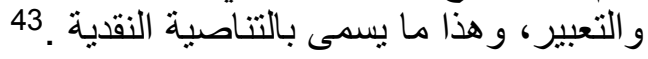

تعد كتابات الناقد اللبناني مارون عبود من أكثر الكتابات النقدية تمثنا لظاهرة

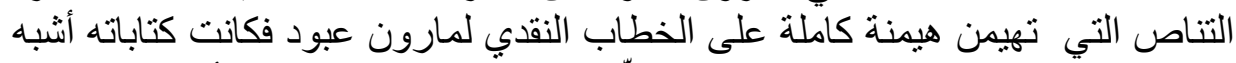

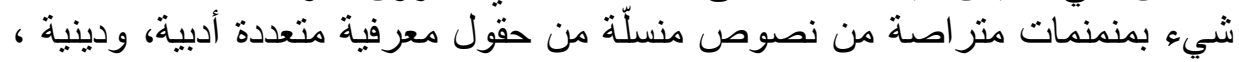
فنية ، تاريخية ، شعبية ، ثقافية ...إلخ تحيل على ثقافة و اسعة و مكنة لغوية منقطعة 


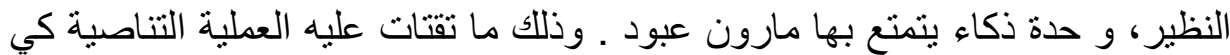

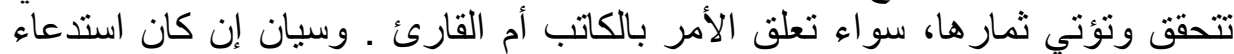

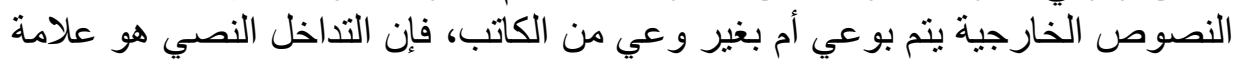

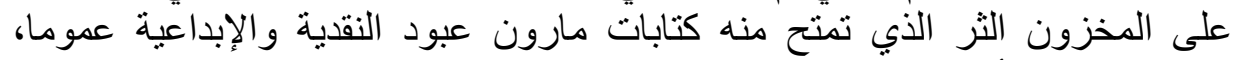

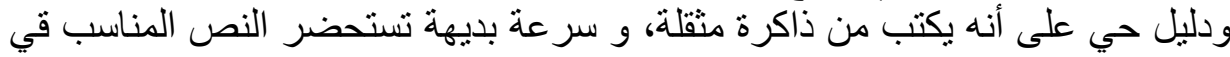

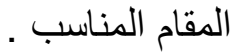

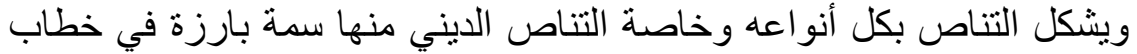

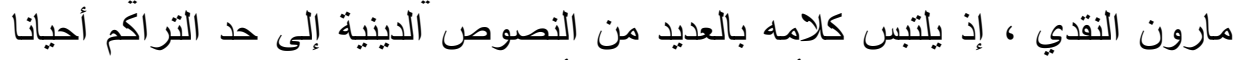

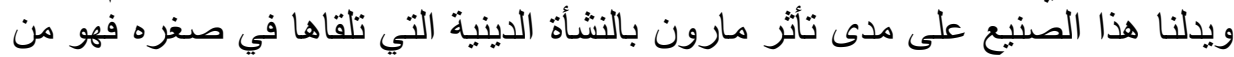

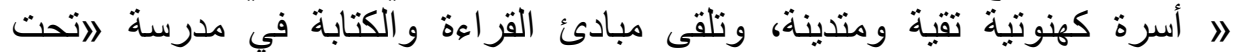

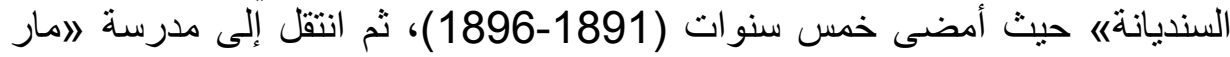

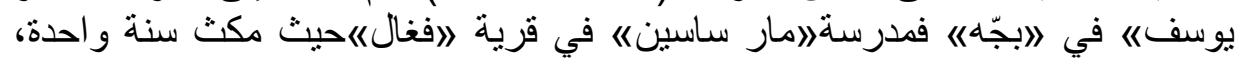

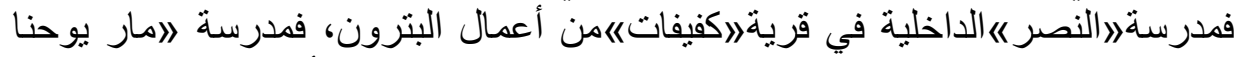

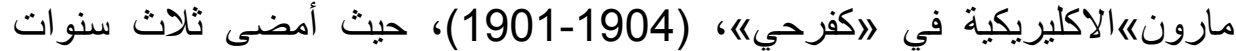

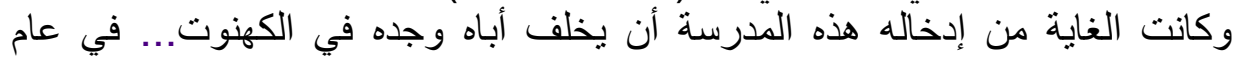

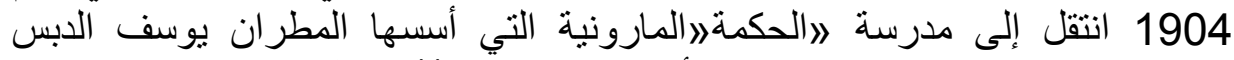

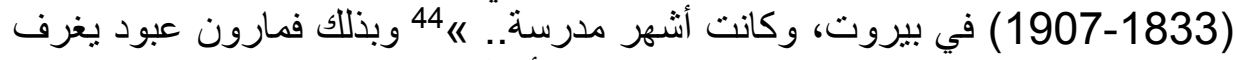

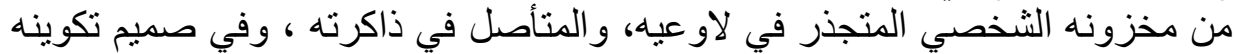

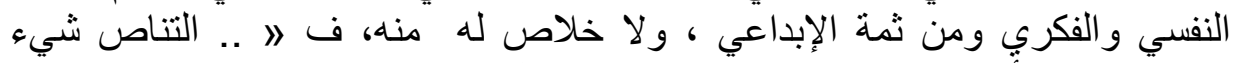

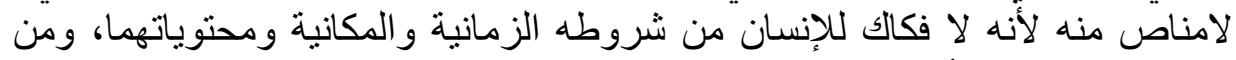

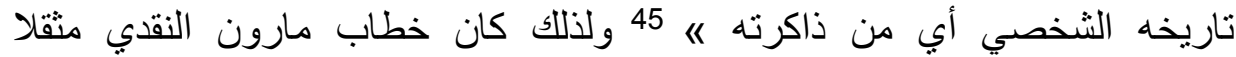

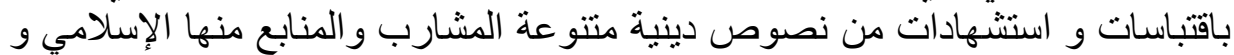

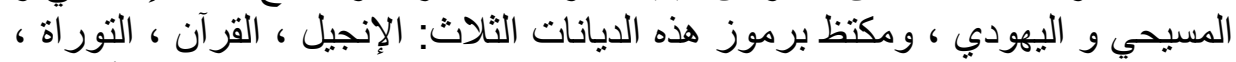

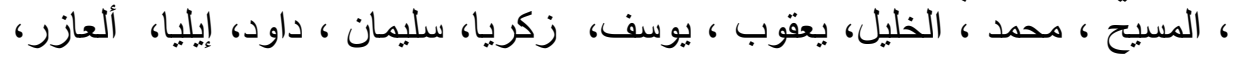

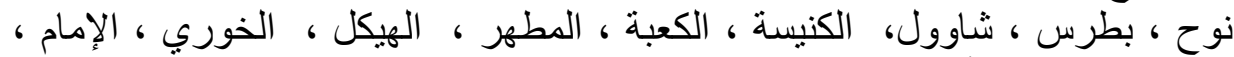

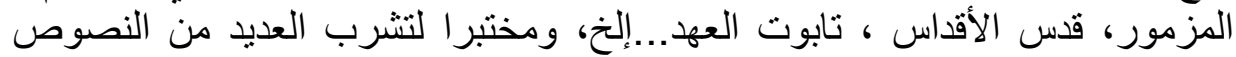

وتحويلها .

و بديهي جدا أن يتأثر مارون عبود بتراثه الثقافي والعقدي، وتنزاحم فيه

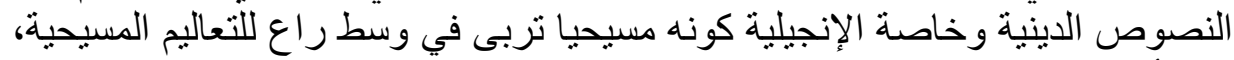

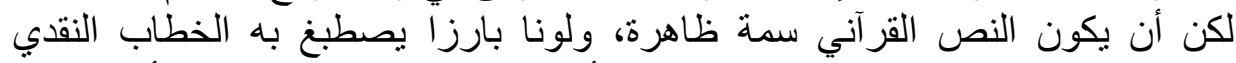

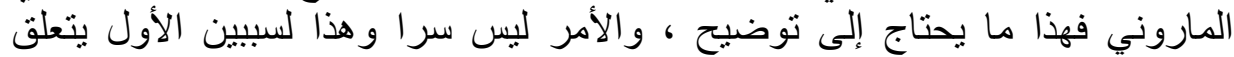

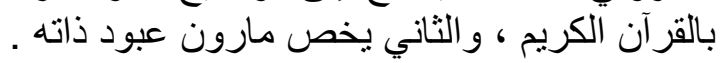

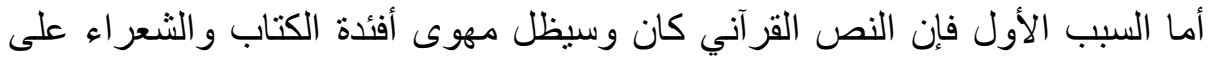

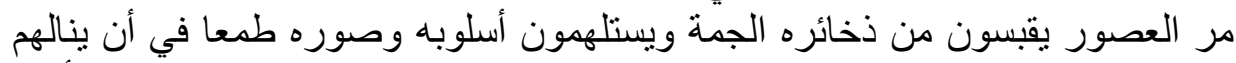

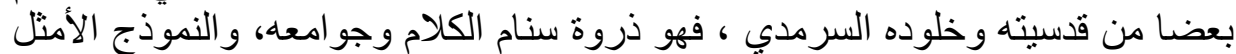

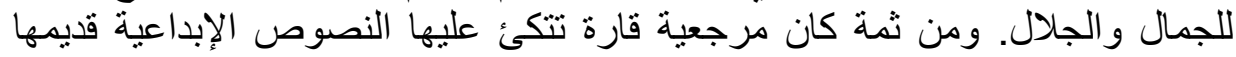

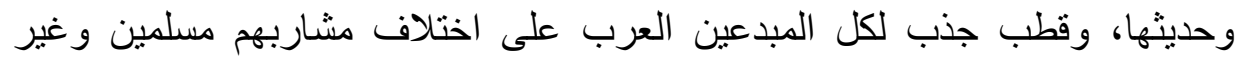

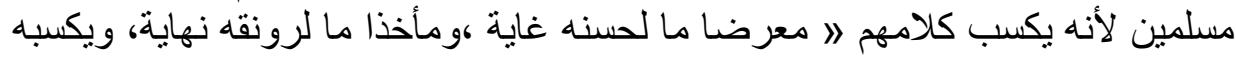

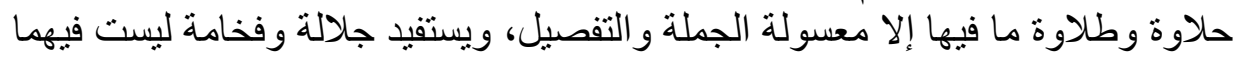

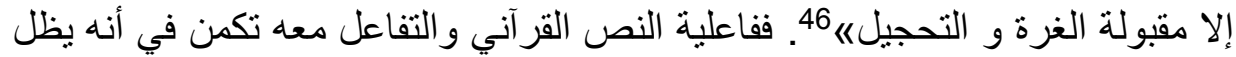

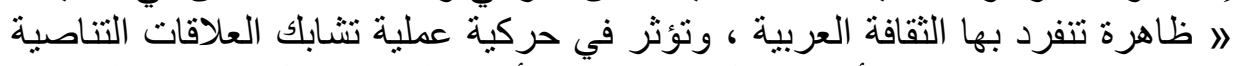

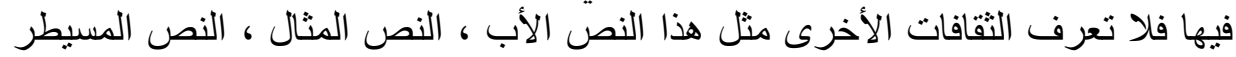

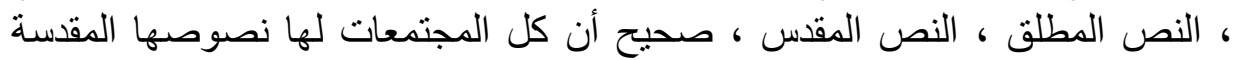
ولكن هذه النصوص لا نطرح نفسها كنموذج أعلى للكمال والجمال اللغوي ...على النى 


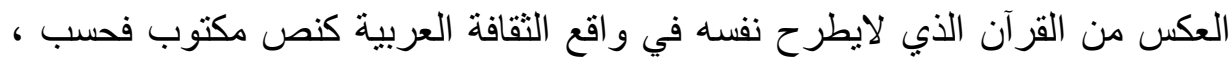

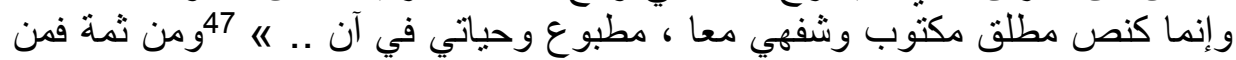

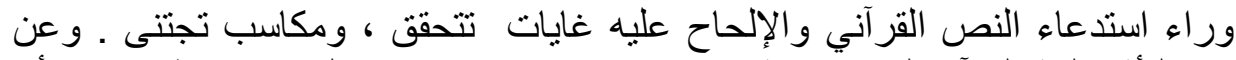

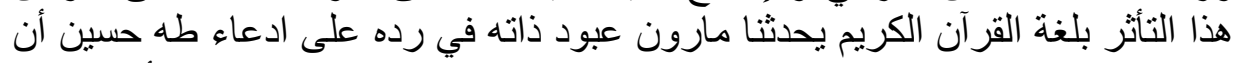

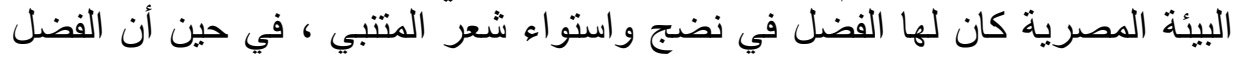

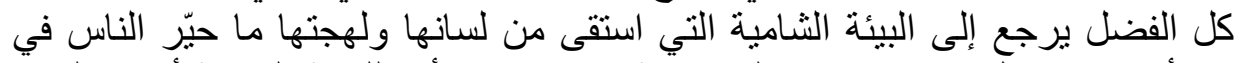

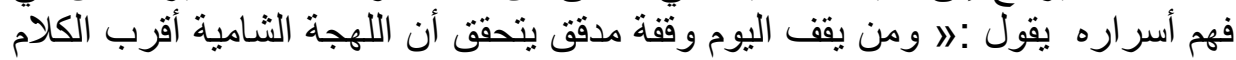

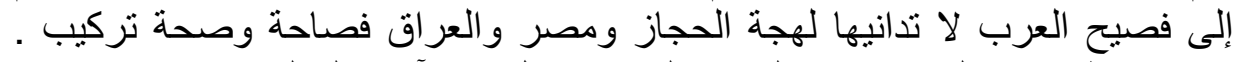
إننا لا ننطق عن الهوى، فخذ الكتاب الكريم وقابل بين آياته الخالدة و تعابيرنا تجدان

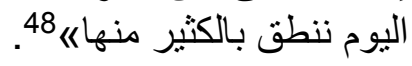

أما بالنسبة للسبب الثاني فالأمر يتعلق بشخصية مارون عبود المهووسة بالتعاليم

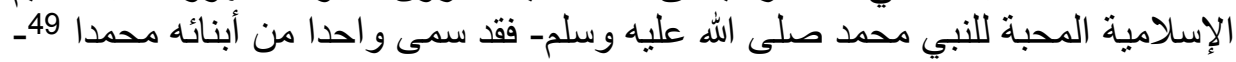

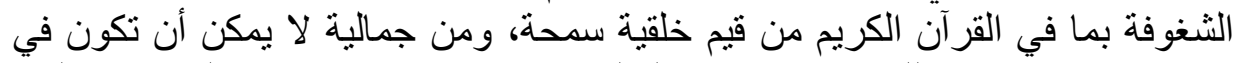

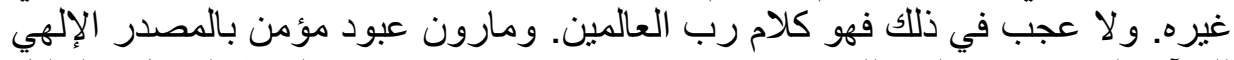

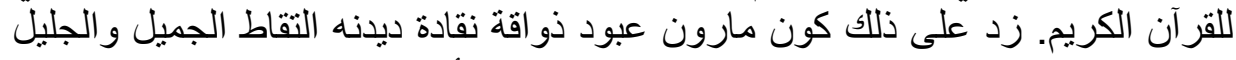

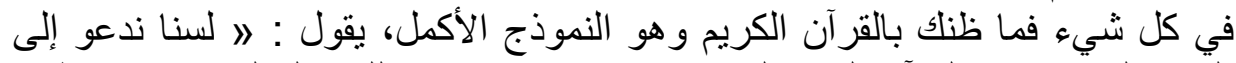

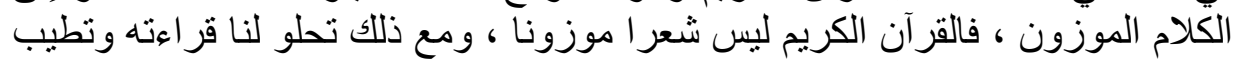

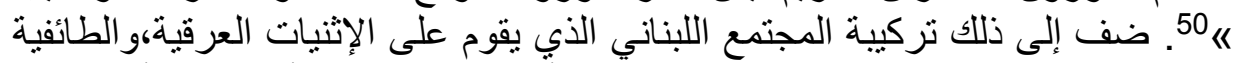

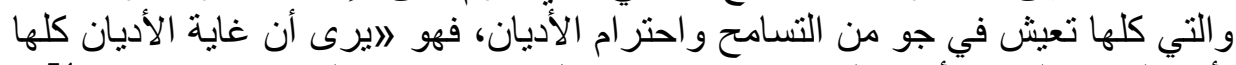

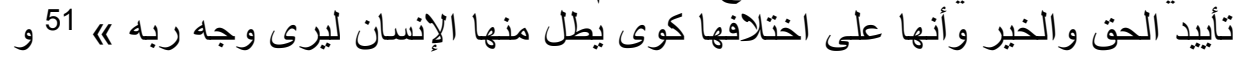

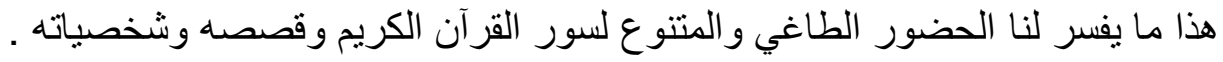

وتوظيف مارون عبود للقرآن الكريم و استدعاؤه أثناء تقليب نظره في النصوص إنها

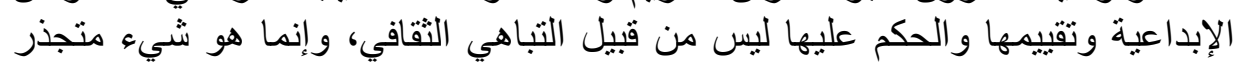

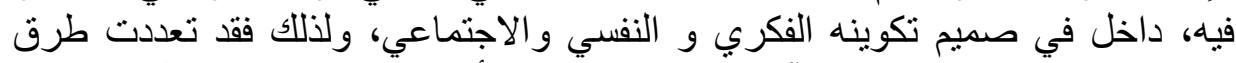

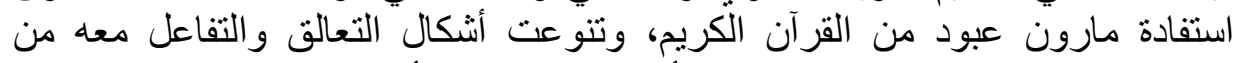

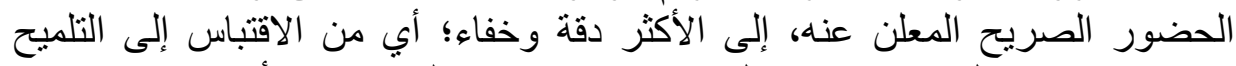

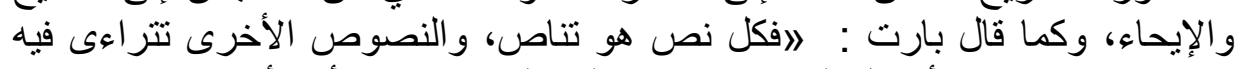

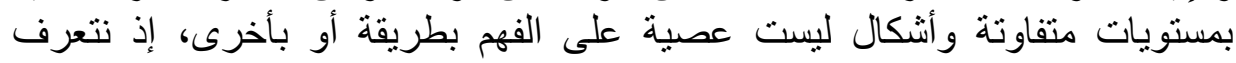

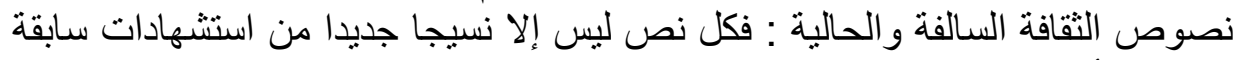

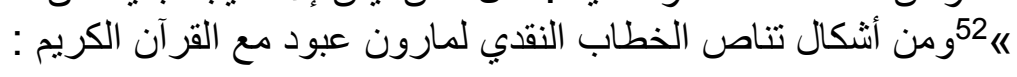

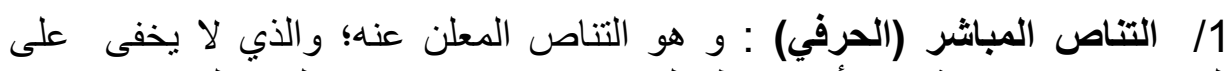

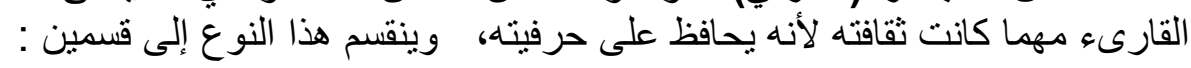

1.1- التناص الاقتباسي المحدد بمزدوجتين .

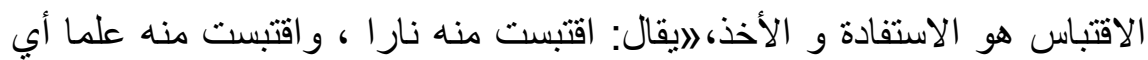

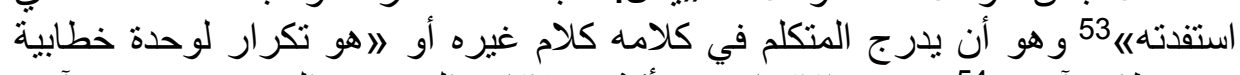

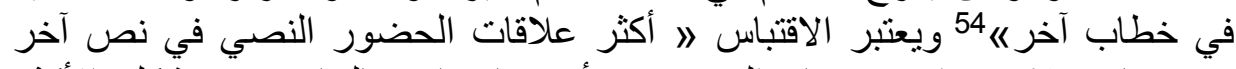

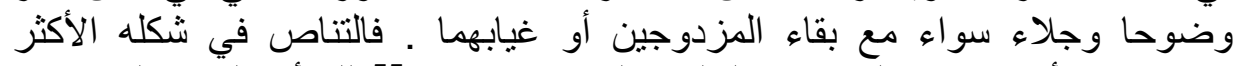

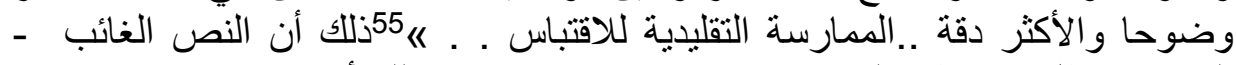

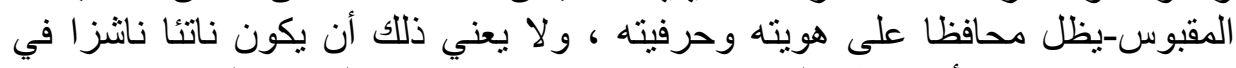

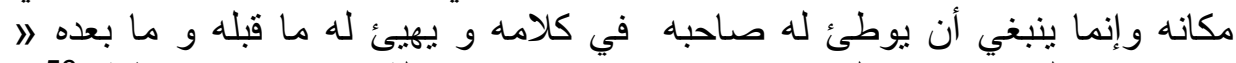

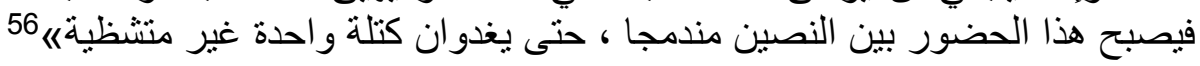




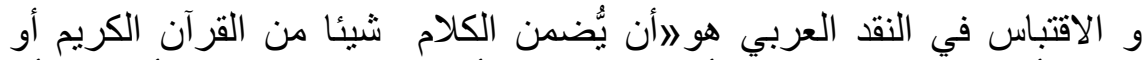

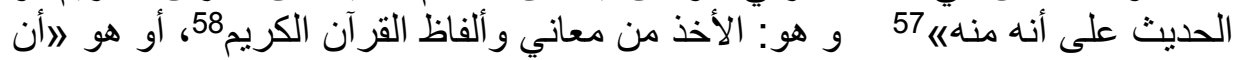

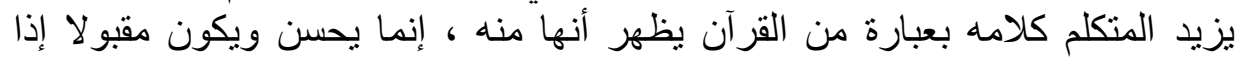

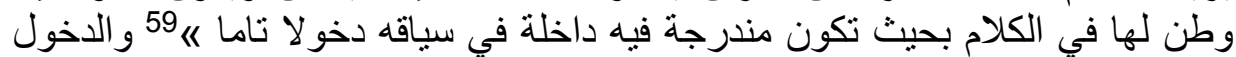

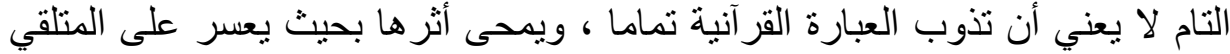

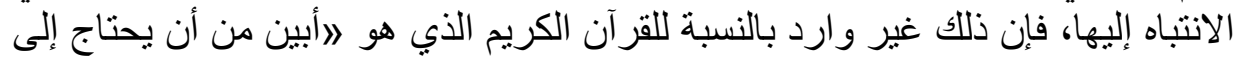

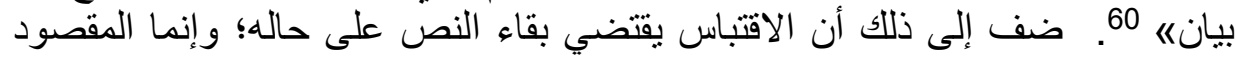

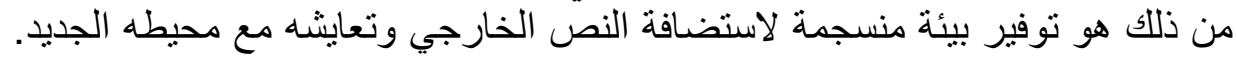

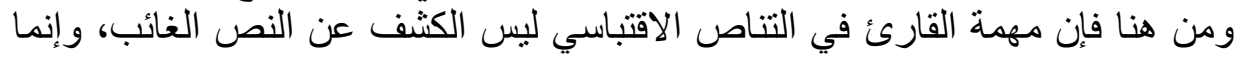

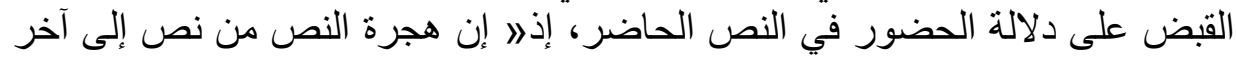

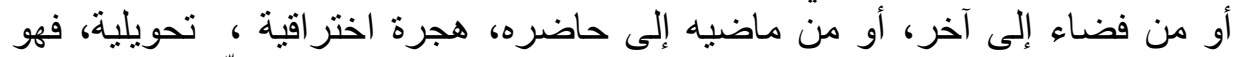

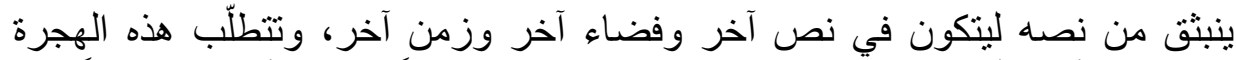

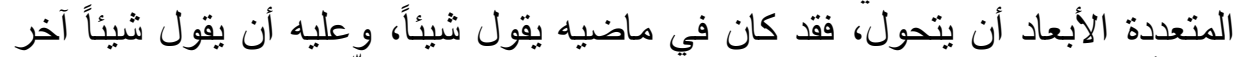

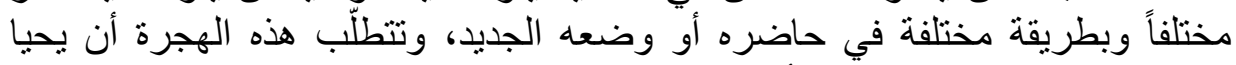

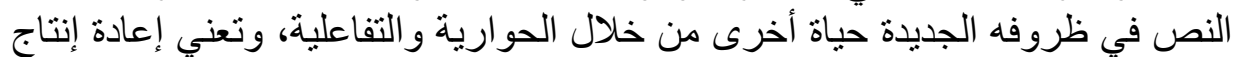

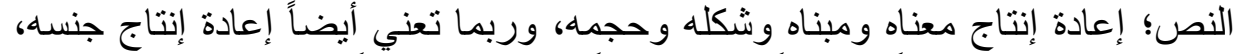

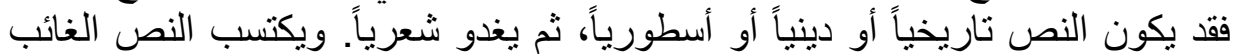

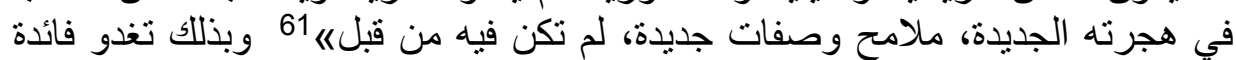

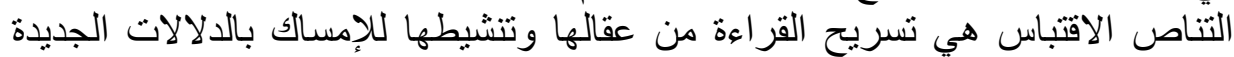

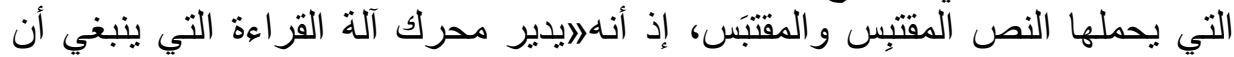

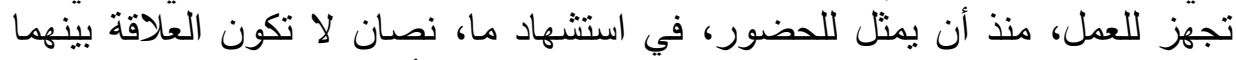

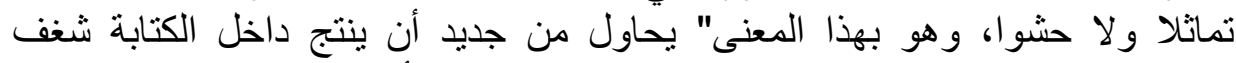

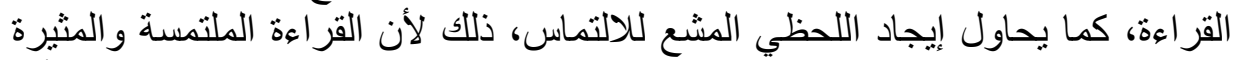

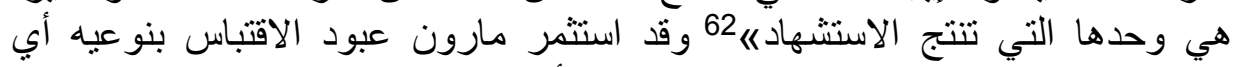

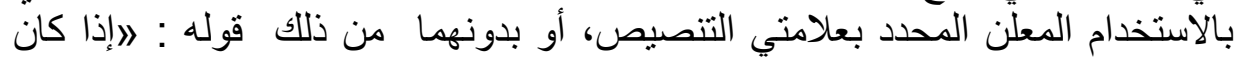

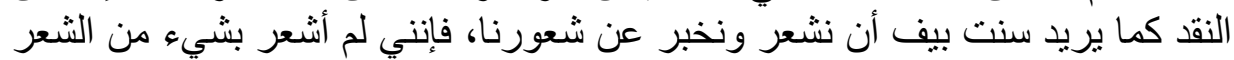

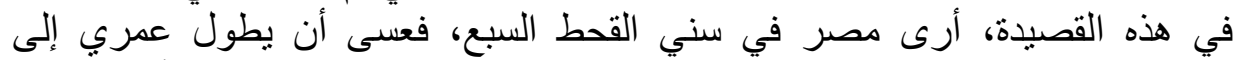

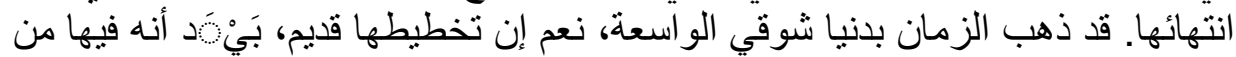

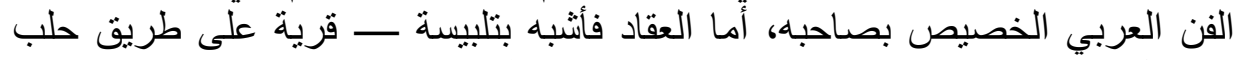

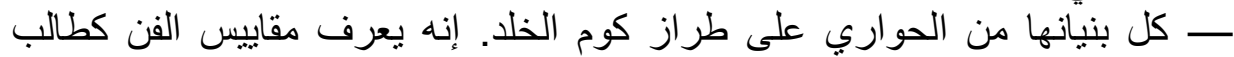

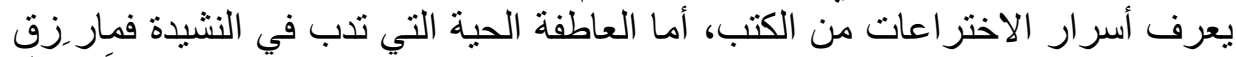

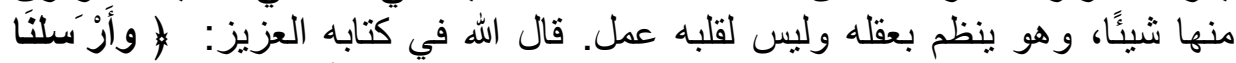

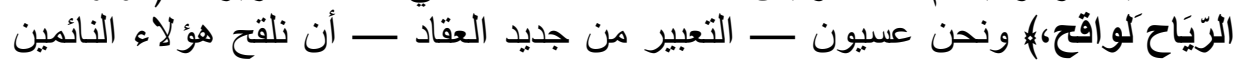

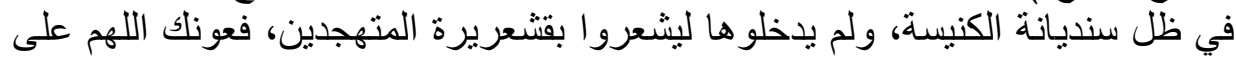

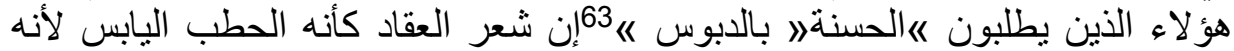

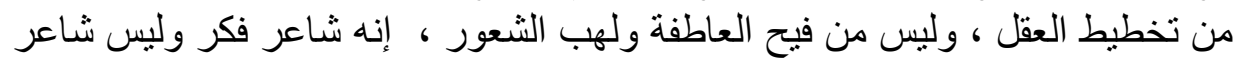

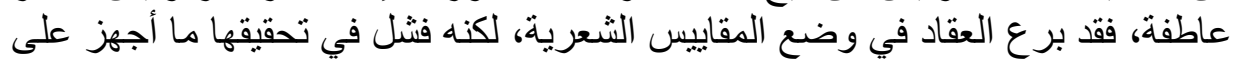

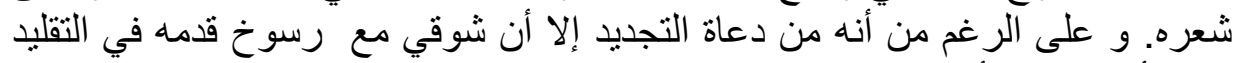

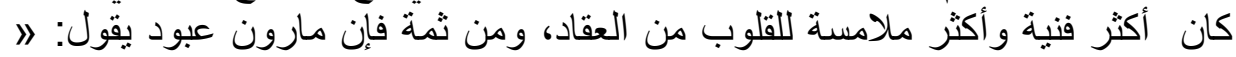

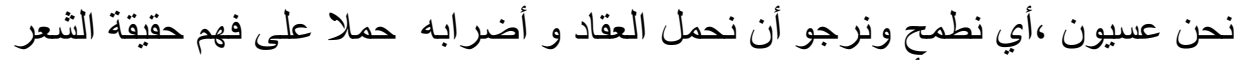

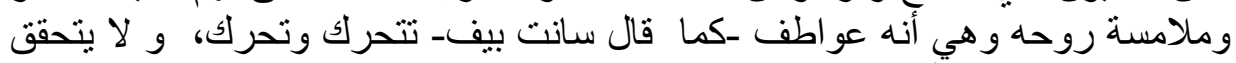

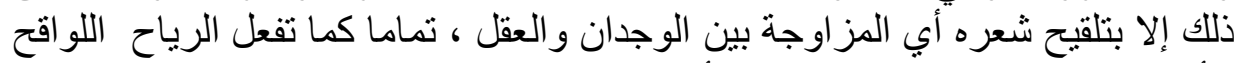

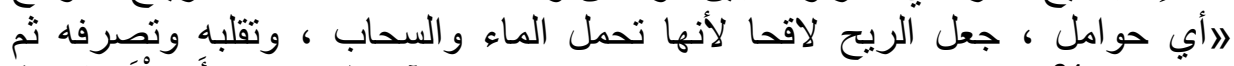

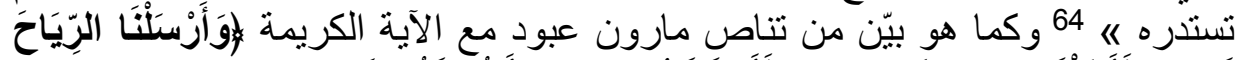

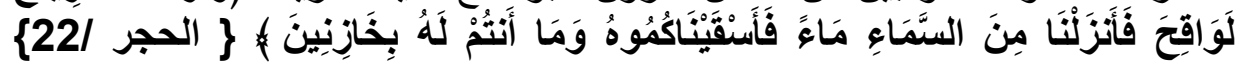

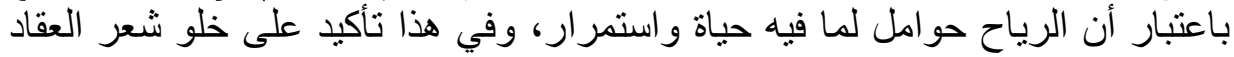


من الحياة ، وحري به أن يلقح شعره بالعاطفة و العقل، و إلا يفعل فإن مارون سيحمله

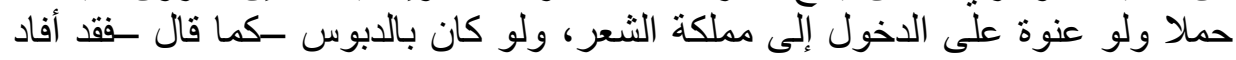

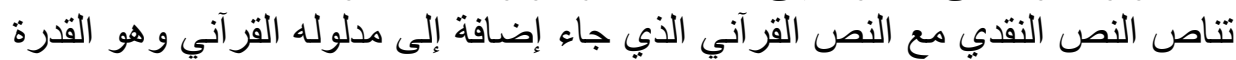

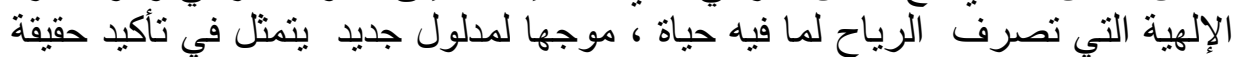

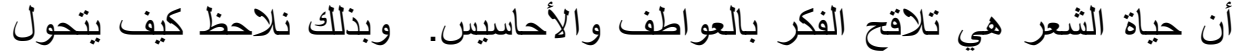

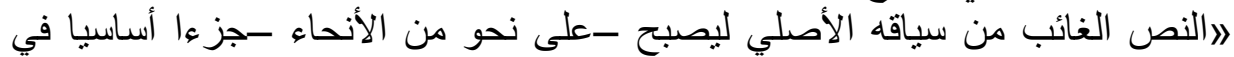

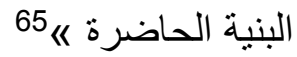

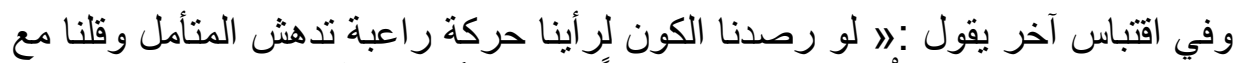

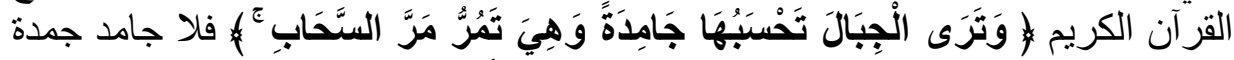

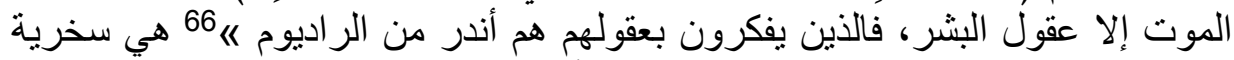

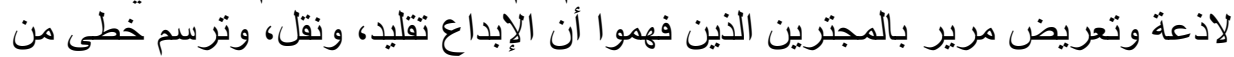

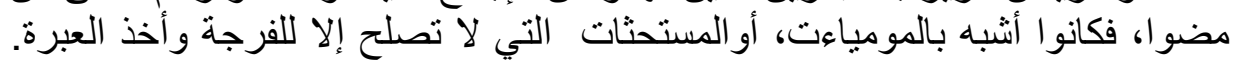

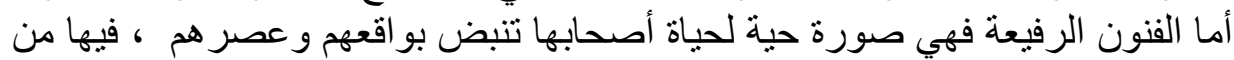

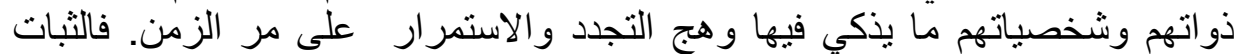

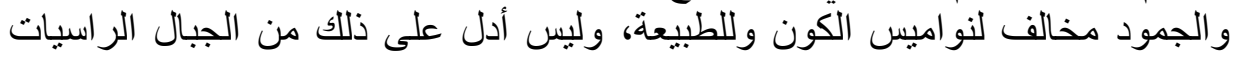

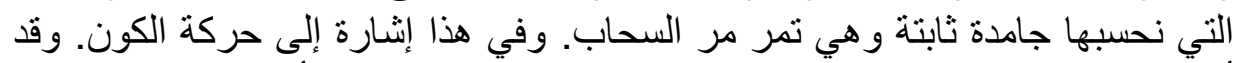
أفاد مارون عبود كثير ا حينما استدعى الآية الكريمة لدعم فكرة أن كل شيء متحرك الثى

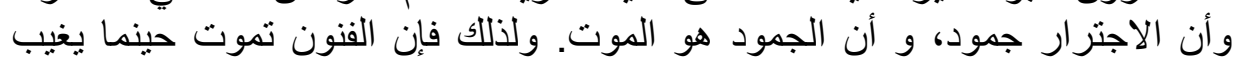

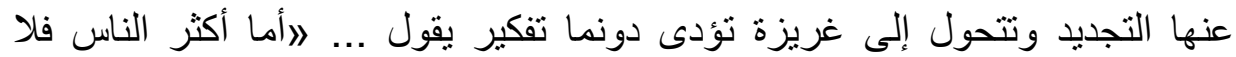

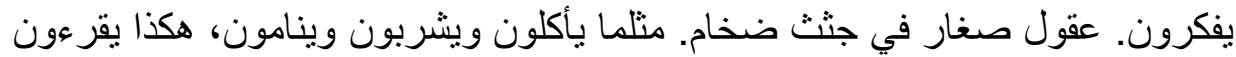

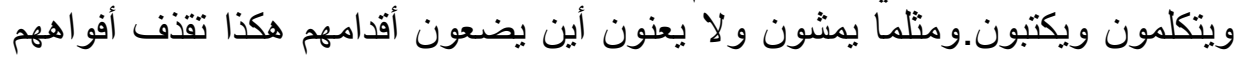

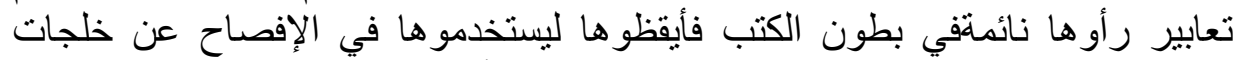

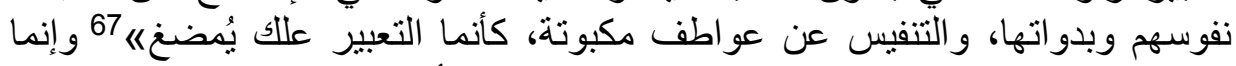

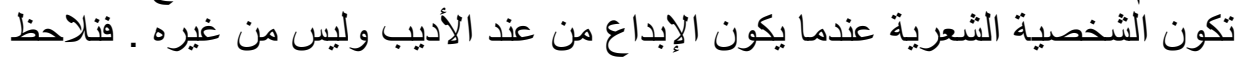

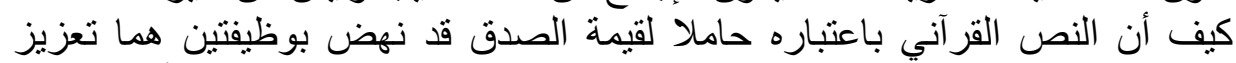

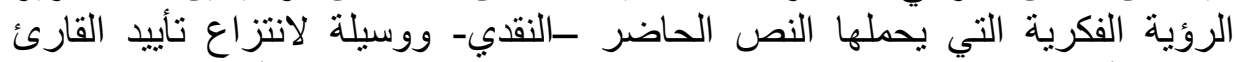

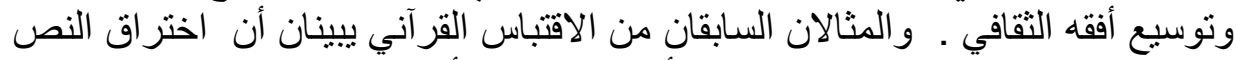

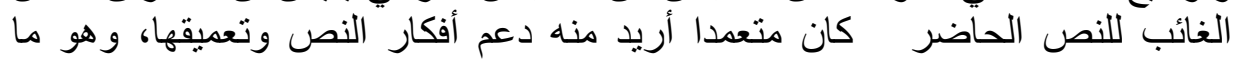
يعرف (بالقصد النقلي )

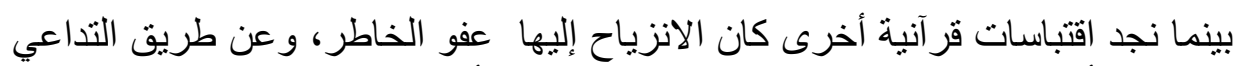

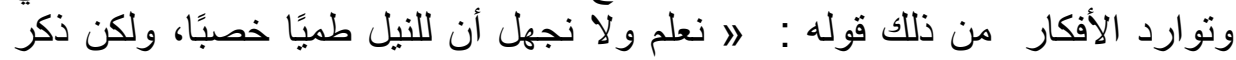

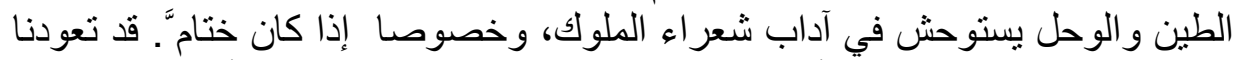

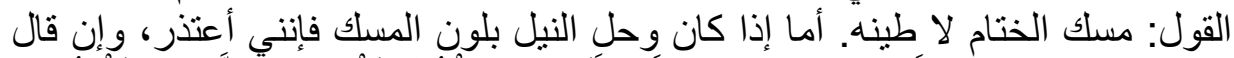

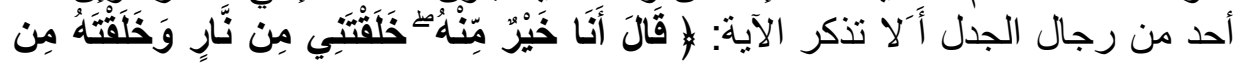

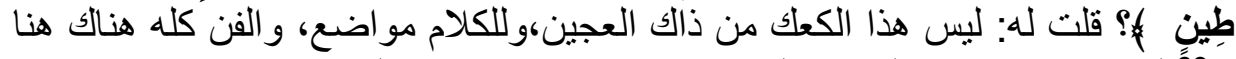

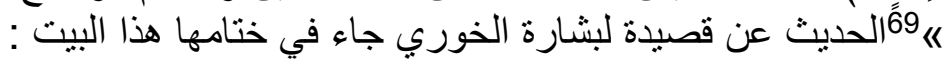

$$
\text { حسدتك الأنهار حين أتاها أن فاروق من هو الك وطينك }
$$

فقد استوقفت الناقد كلمة طين التي أسفت بمعنى البيت، ذلك أن الثناعر استخدمها

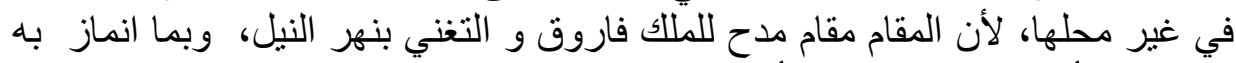

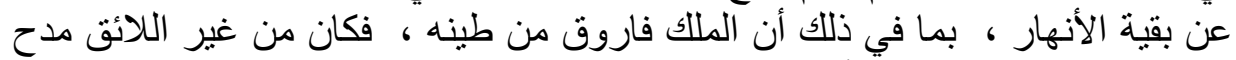

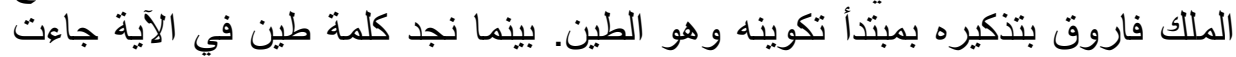

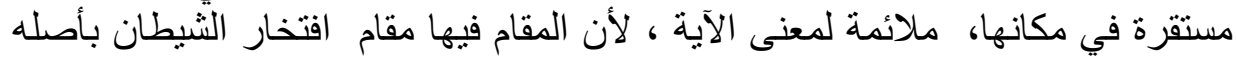

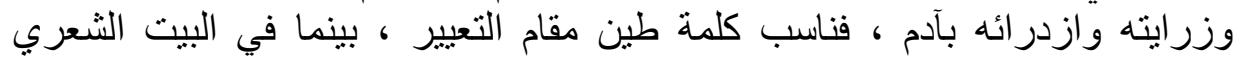


فالمقام فيه مقام مدح و افتخار. و وعلى الرغم من أن كلمة طين استخدمت في إطار

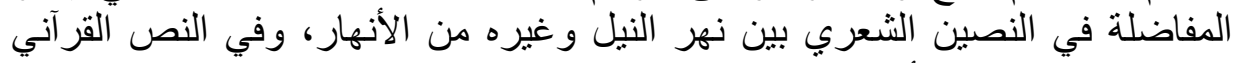

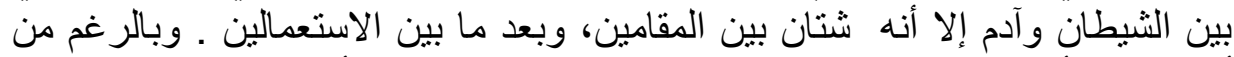

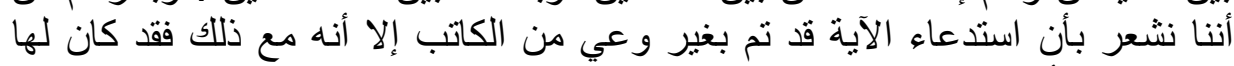

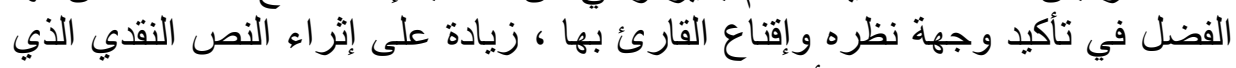

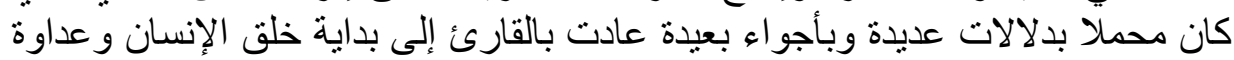
الثيطان له ... و غير ذلان ذلك.

$$
\begin{aligned}
& \text { ويقول في نص آخر نقد فيه قصيدة للثاعر بشارة الخوري يهنئ فيها رئيس }
\end{aligned}
$$

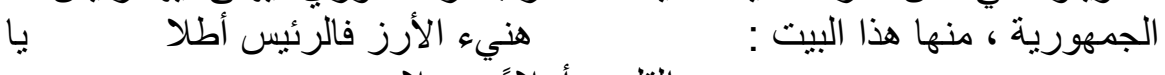

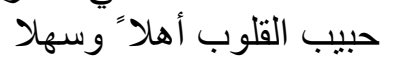

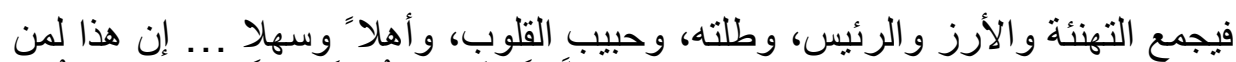

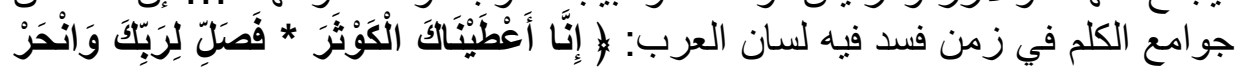

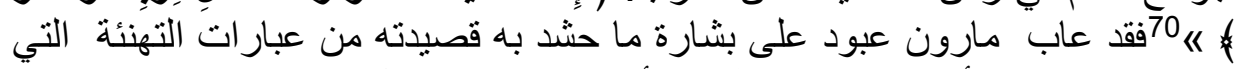

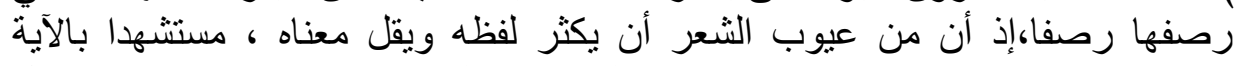

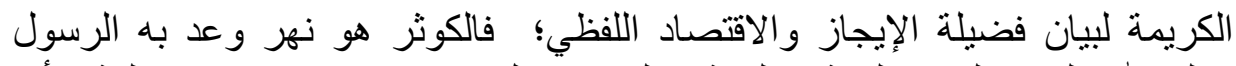

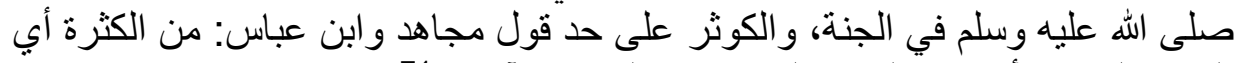

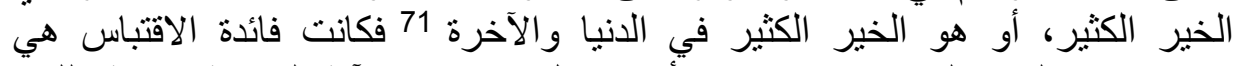

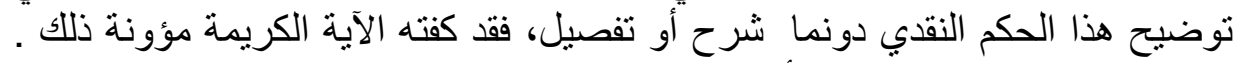

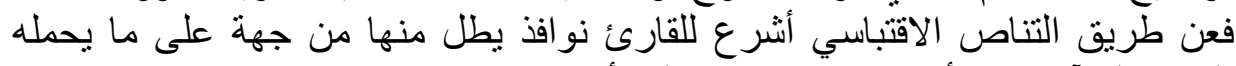

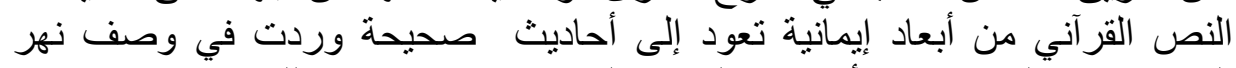

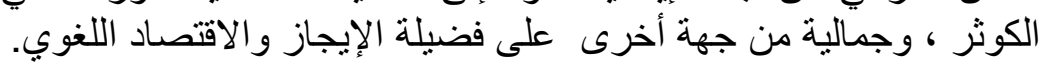

ونراه في اقتباس آخر يستحضر من القرآن ما يجلي به رأيه في شعر العقاد، يقول:

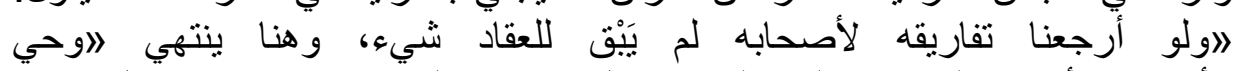

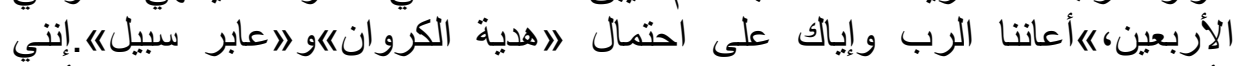

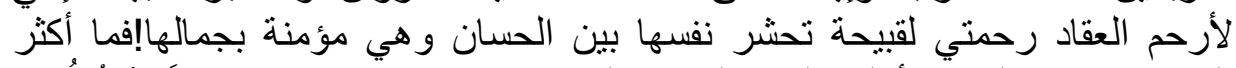

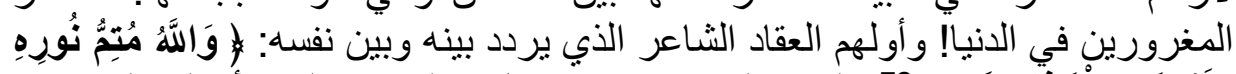

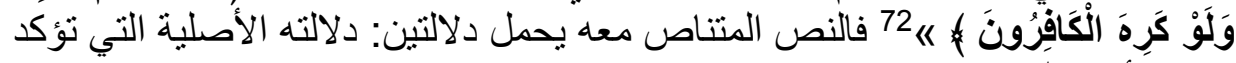

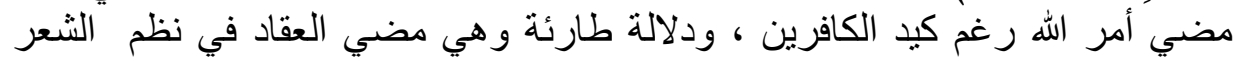

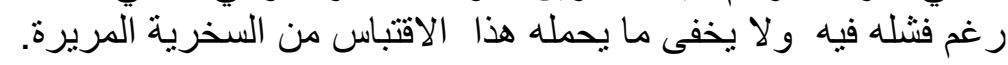
وفي تناص اقتباسي آخر يقول : لا و أبى ظريف إلا أن يطربنا بمطلعها:

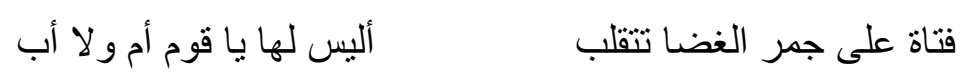

فقلت أعوذ بالله من شر شيطانك يا حليم، إن فتاتك هذه مثل سفود النابغة الذي نسوه عند أنداء

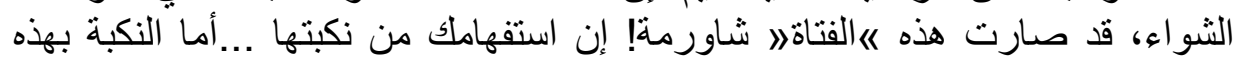

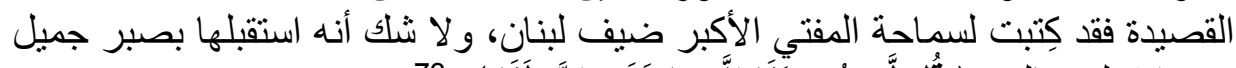

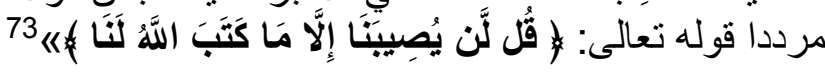

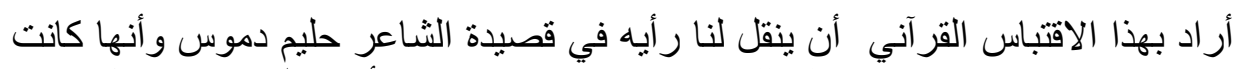

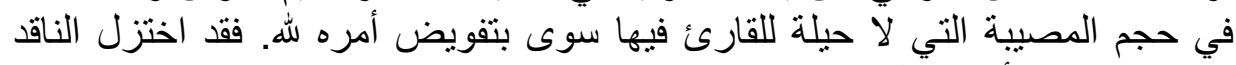

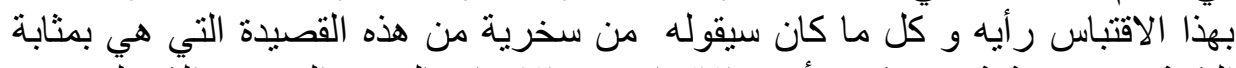

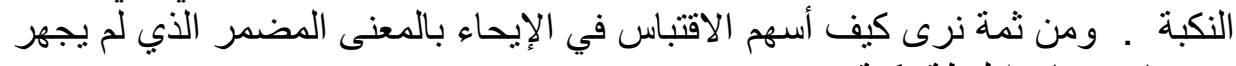
به صاحبه ماعدا لفظة نكبة . تونة 


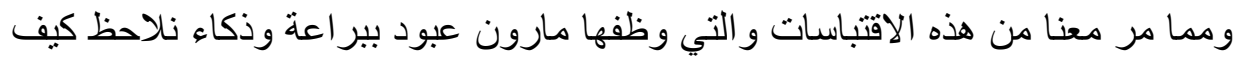

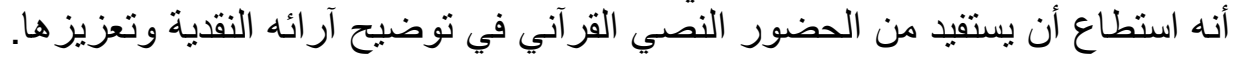

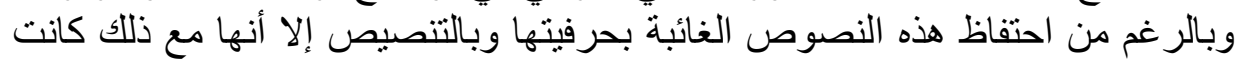

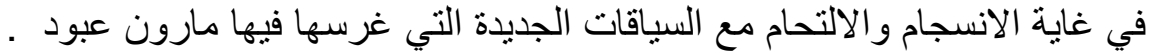

\section{1- التناص الاقتباسي الغير محدد بمزدوجتين :}

و إلى جانب التناص الاقتباسي بالقرآن المحدد بالمزدوجتين، نجد تناصات

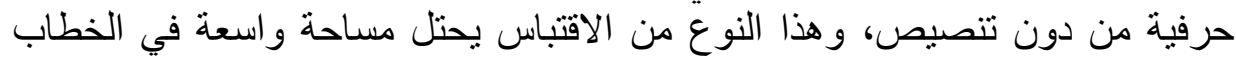

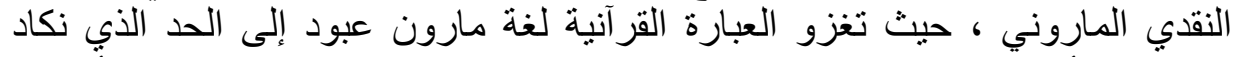

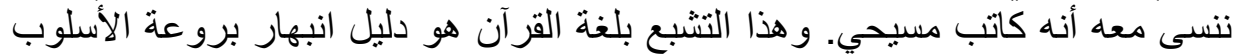

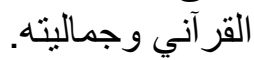

وقد سلك مارون عبود طريقين في التعامل مع العبارة القرآنية وذلك بالإبقاء عليها كما

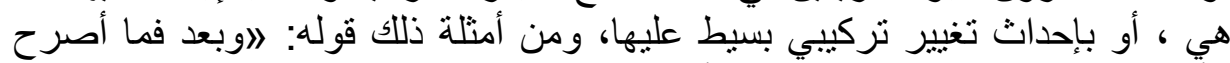

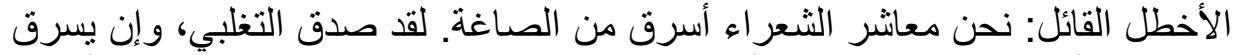

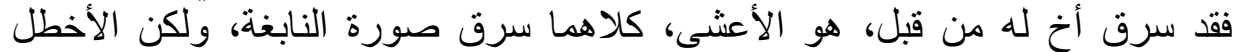

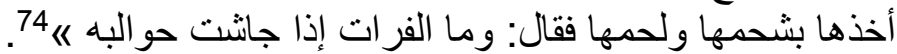

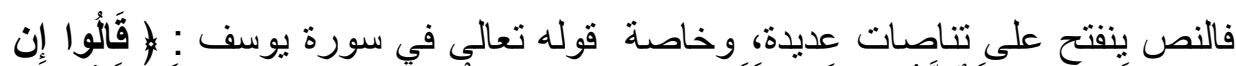

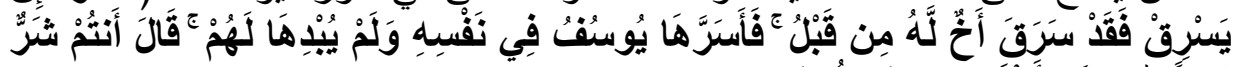

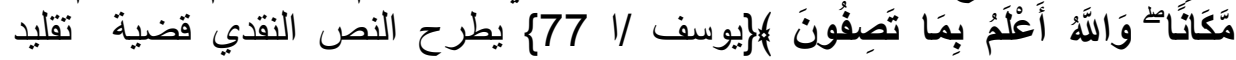

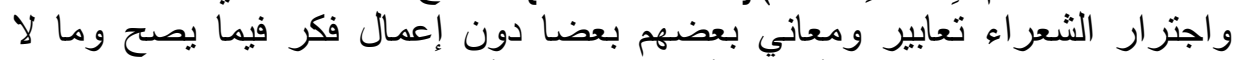

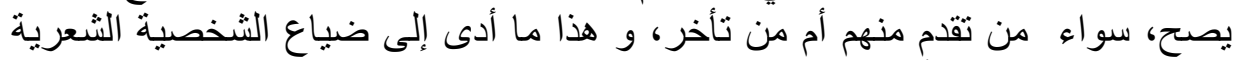

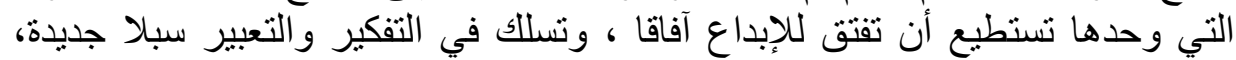

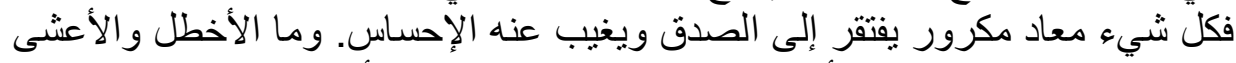

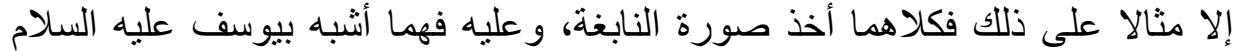

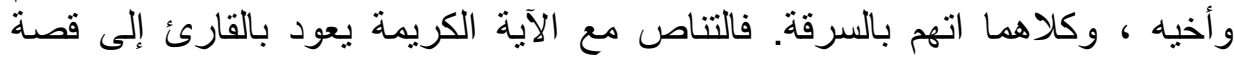

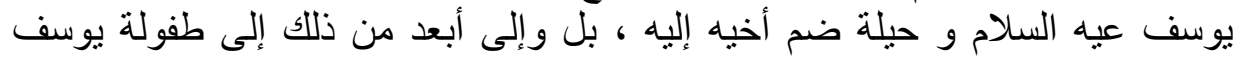

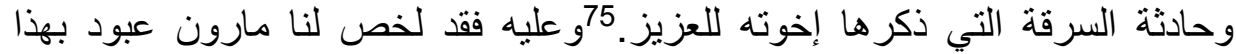

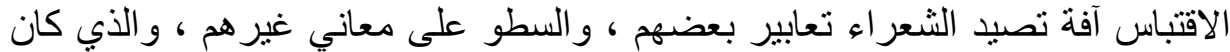

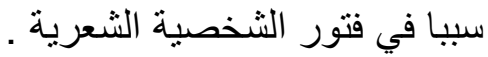

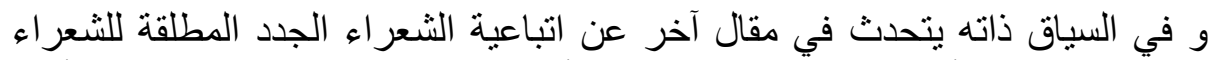

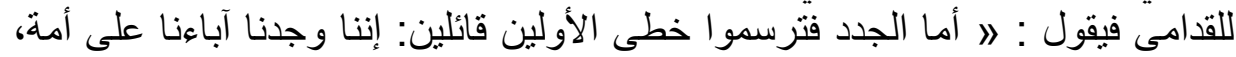

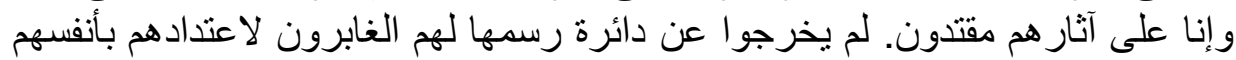

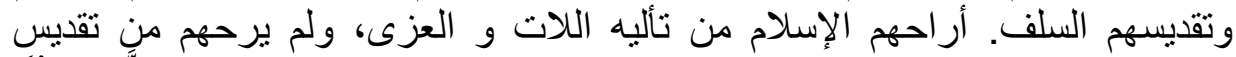

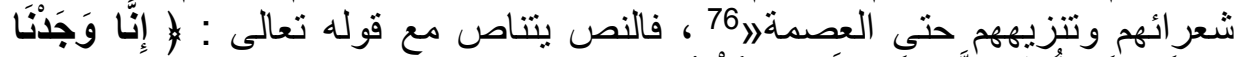

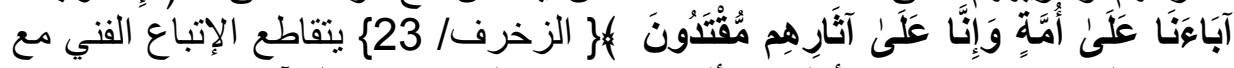

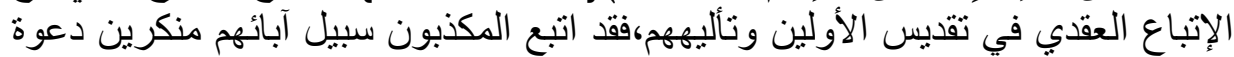

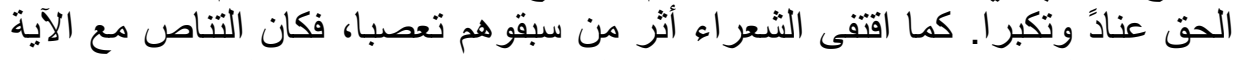

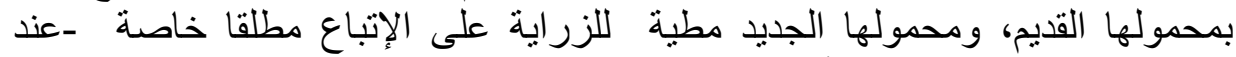

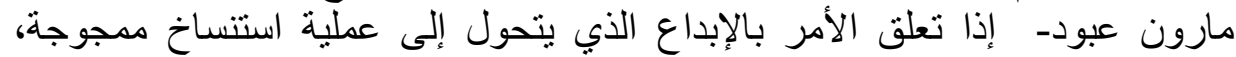

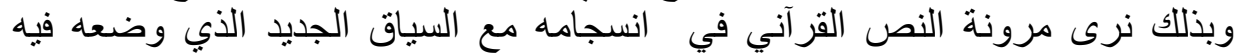
مارون عبود، دون أن يفقد قداسته.

و يصف في تتاص آخر شعر البحتري بأنه في غاية الإحكام فيقول: لاوبعد، فماذا

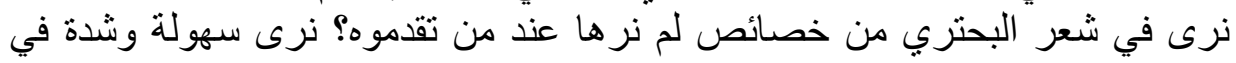


وقت معا، نرى شاعرا لا يُقدم كلمة ولا يُؤخر كلمة، فنظمه كنظم العقد حقا. قصيدته

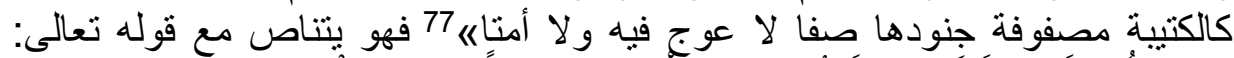

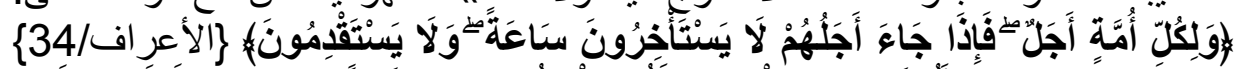

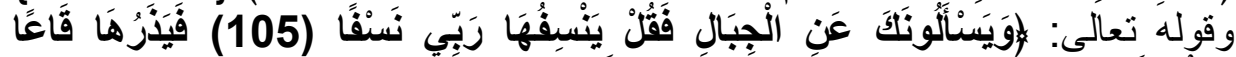

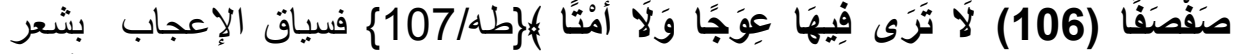

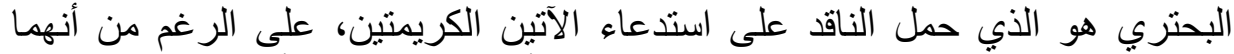

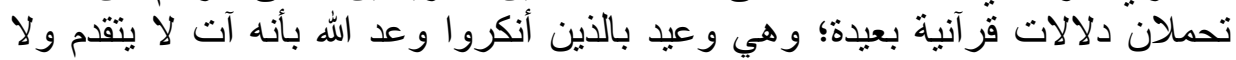

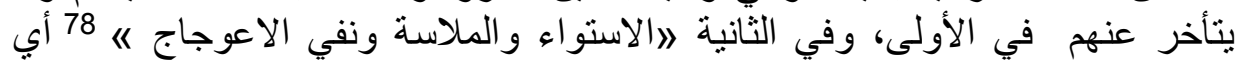

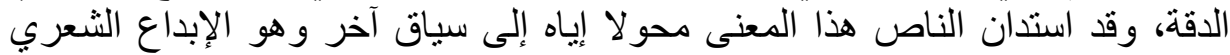

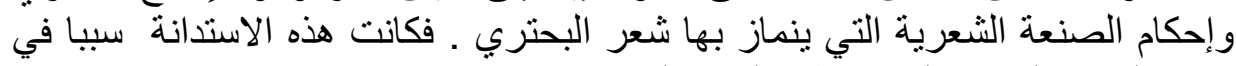

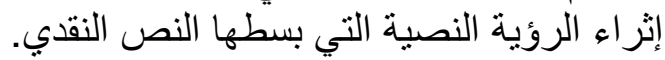

$$
\begin{aligned}
& \text { ويعلق على تعليق طه حسين على أبيات المتنبي التي قال فيها : } \\
& \text { أي محل أرتقي ؟! }
\end{aligned}
$$

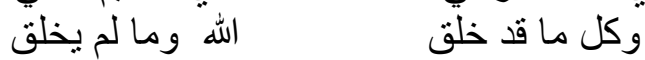

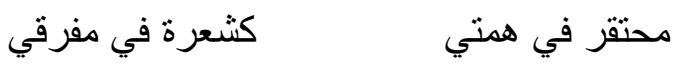

ما رأيت المتنبي في لاأي محل أرتقيه إلا محموما حرارته فوق الأربعين أو

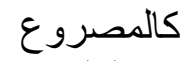

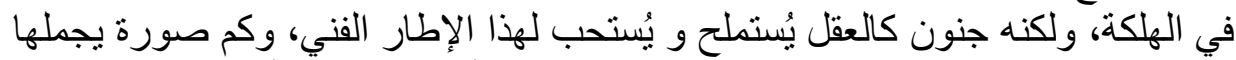

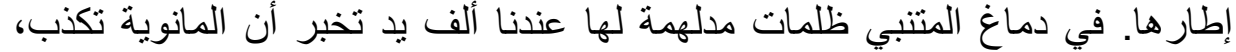

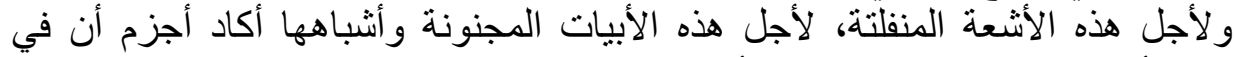

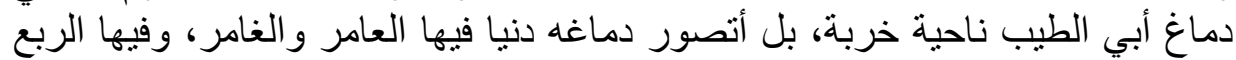

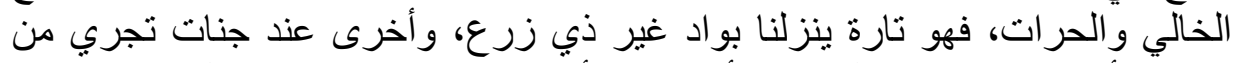

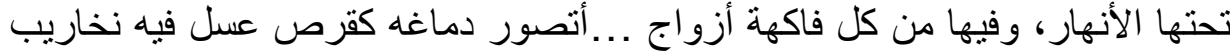

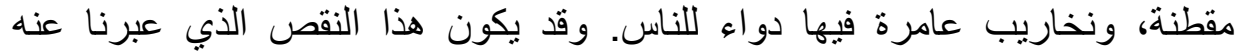

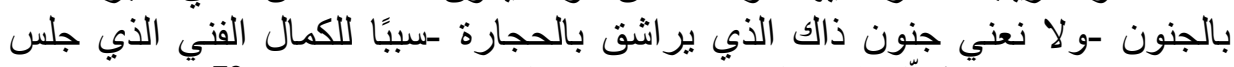

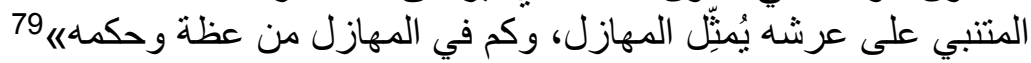

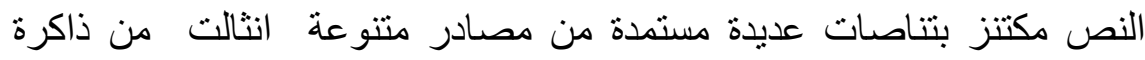

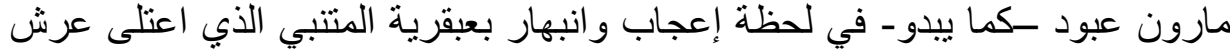

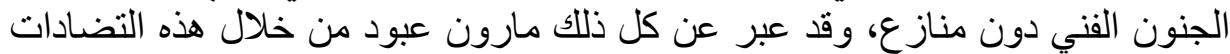

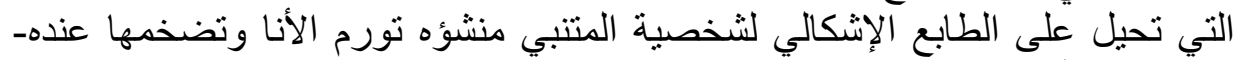

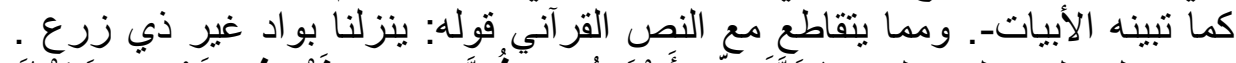

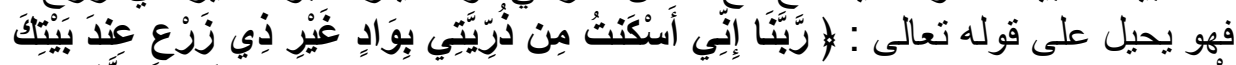

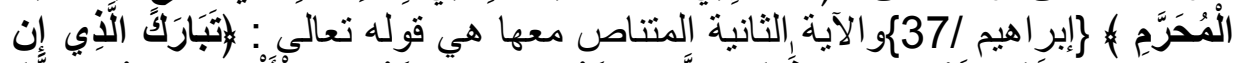

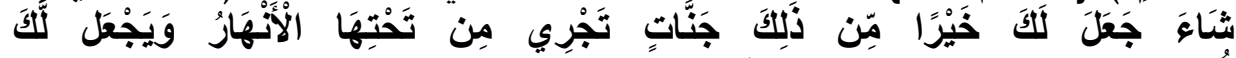

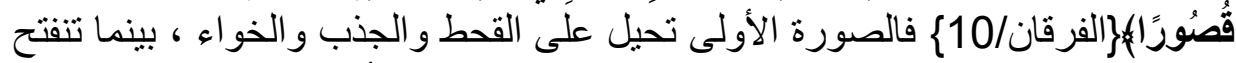

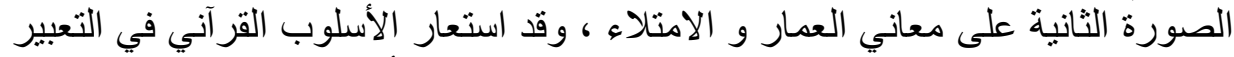

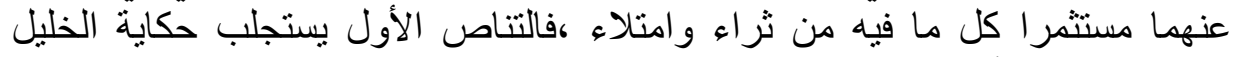

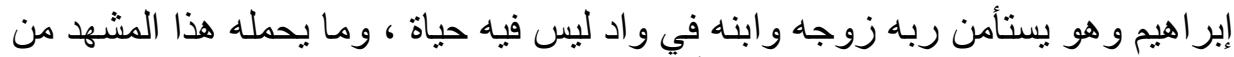

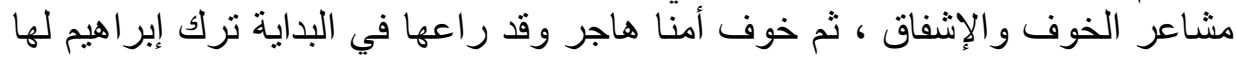

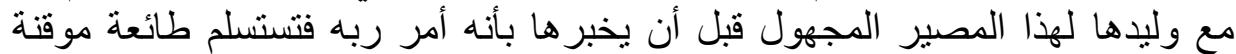

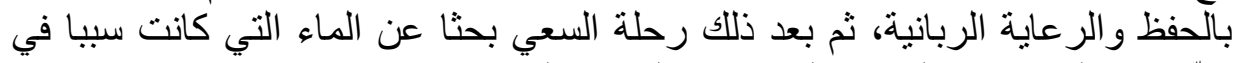

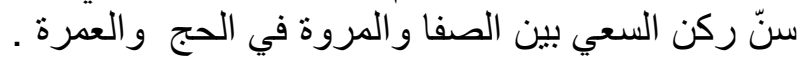




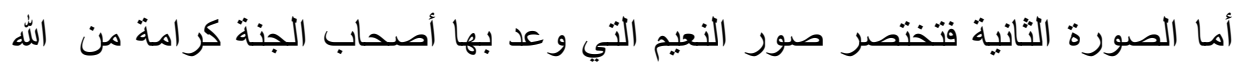

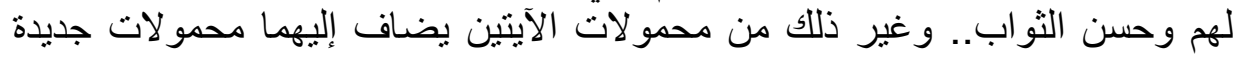

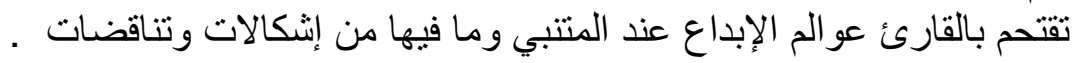

ويقول في مقاله ثلاث دواوين للعقاد: لافعدت بخيبة أردد: ما لي لا أرى

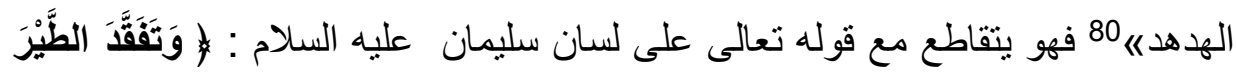

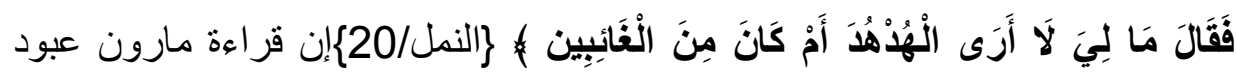
لشعر العقاد هي رحلة بحث مضنية عن الشعر الحقيقي الذي برع العقاد في التنظير له وتحديد أصوله، والأعجب أن لا يكون لكل ذلك أثر في دواوينه كلها. ولذلك نرى مارون عبود يستنجد بالهدهد الذي يرتبط في الذاكرة الدينية والشعبية بالرغبة الجامحة في المعرفة وكثف المجهول علّه يأتيه بالنبأ اليقين. فهدهد سليمان لا.. لم يكتف يلف بالتحليق في نطاقه المحدود، و إنما قام بممارسة عملية الكثف لعو الم جديدة ، «81 من أجل ذلك استتجد مارون عبود بالهدهد ليكثف له خبء شعر العقاد لكن دون جدوى ، وقد عبر عن هذه الخيبة بهذا الاستفهام التعجبي الذي يحيل على انقطاع الرجاء في العثور على الثعر الصادق بتعريف العقاد. وبذلك نرى أن التناص مع النص القرآني قد أسعف الناص في نقل إحساسه بالخيبة وتحطم توقعه على صخرة الو اقع الثعري للعقاد ، فإذا كان هدهد سليمان قد اكتشف مملكة سبأ ،التي ساقهاوملكتها إلى التوحيد ، فإن هدهد مارون عبود غير موجود و لا يحيل على شيء. كما أسهم في تسريب هذا الحكم اليائس إلى المتلقي الذي لا يملك إلا التسليم لمارون عبود سيما إذا كان مطلعا على نقد العقاد العنيف لخصومهه وخاصة شوقي .

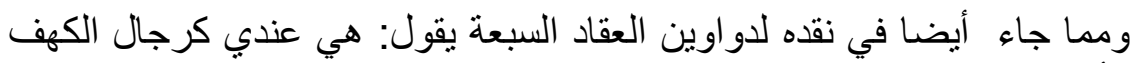

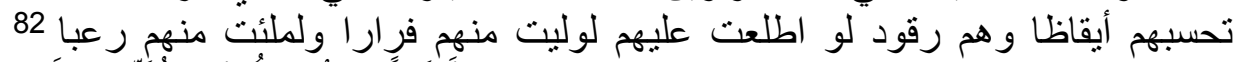

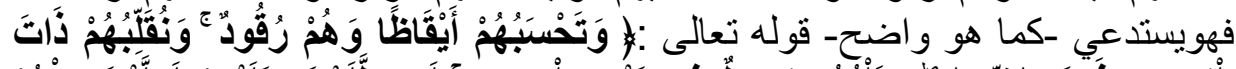

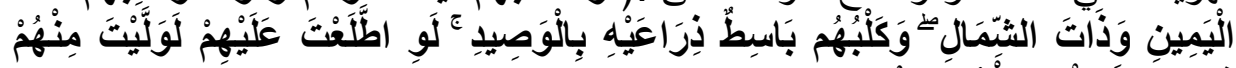

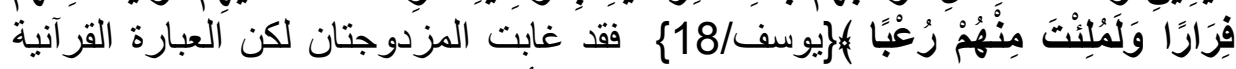

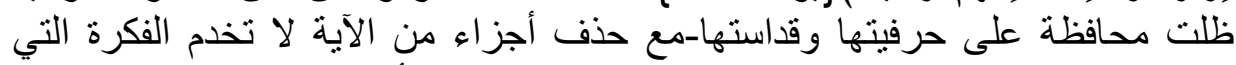

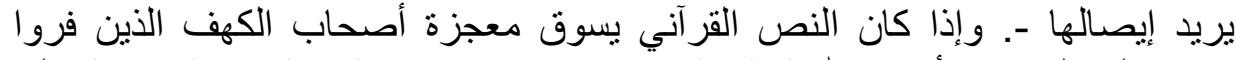

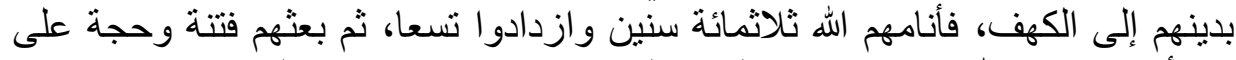

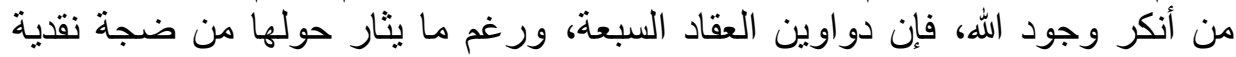

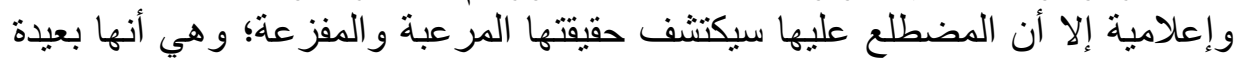

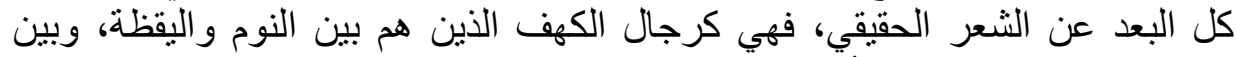

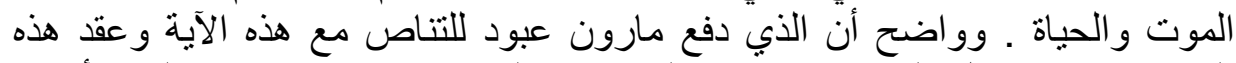

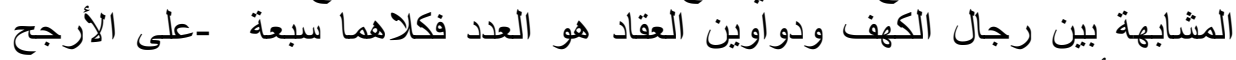

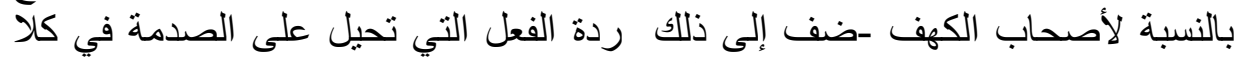

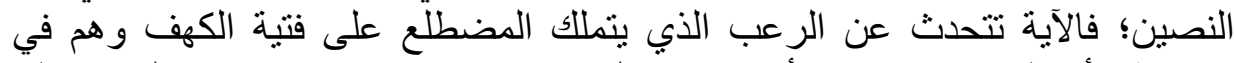
وضعية الأيقاظ بينما هم رقود. أما دواوين العقاد فإن ما فيها من فقر فني لا يليق بمنظر العر فئر 
للإبداع الثعري كالعقاد، فتلك هي الصدمة، وذللك هو الفزع الذي يصيب القارئ وهو

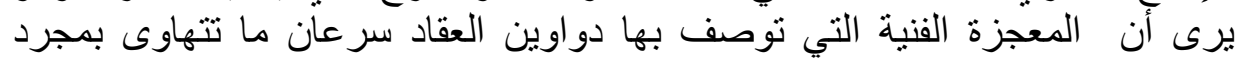

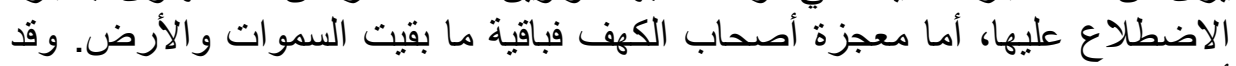

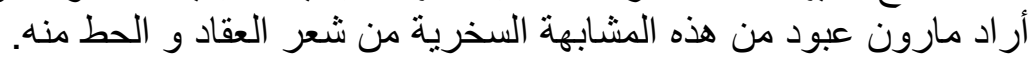

هكذا يوظف مارون عبود التناص الاقتباسي من أجل تجلية موقفه النقدي وتدعيم

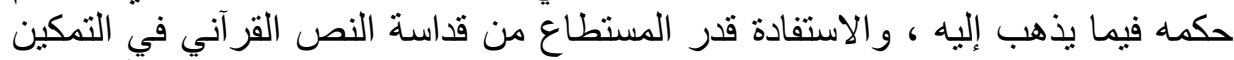

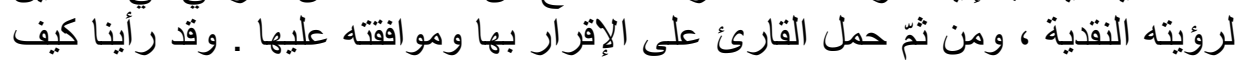

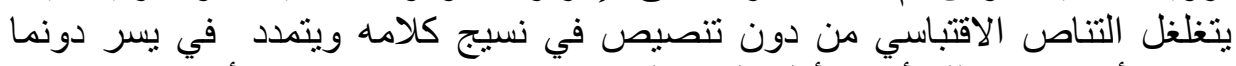

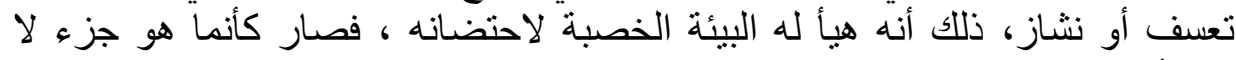

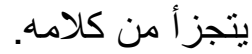

/2 التناص الغير مباشر (الغير حرفي) : وهو أن يكون حضور النص الغائب

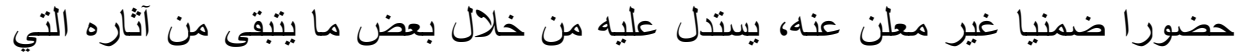

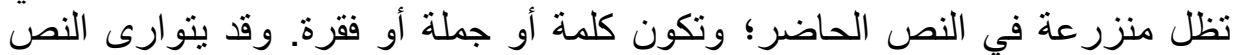

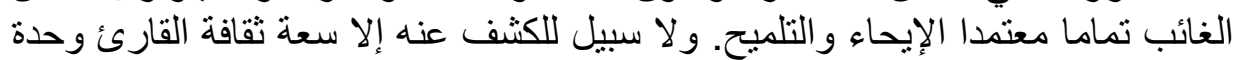

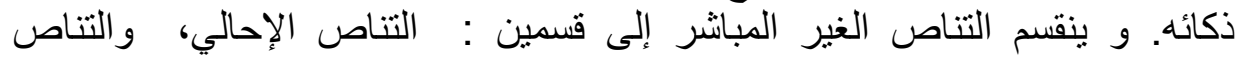
الإيحائي.

2.1- التناص الإحالي: يعرّف بلا الاستدانة غير الحرفية المستترة 《/83 والمقصود به

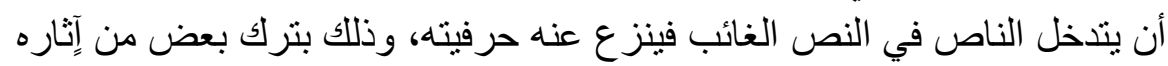

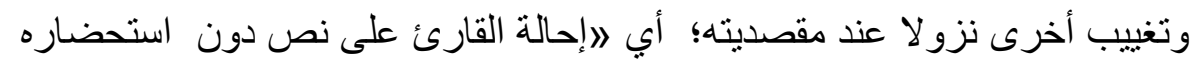

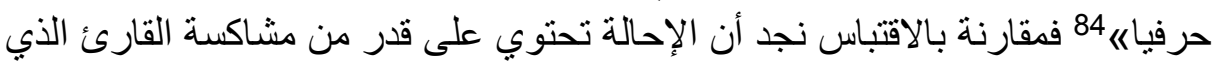

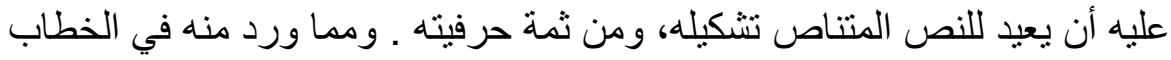

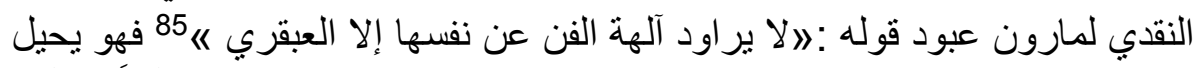

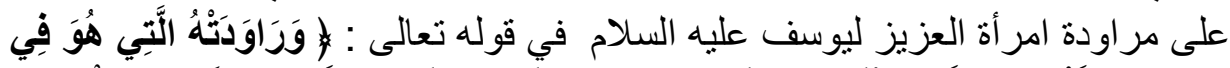

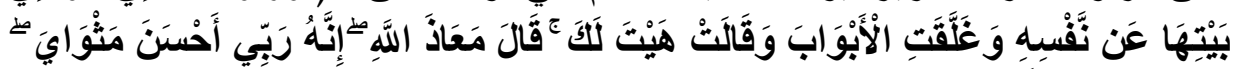

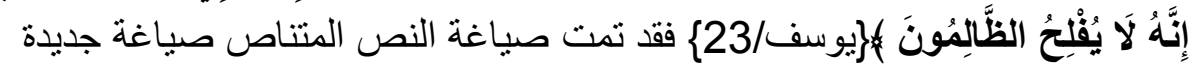

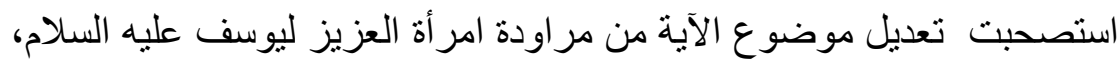

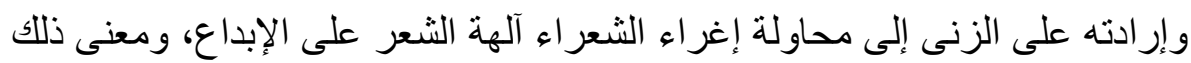

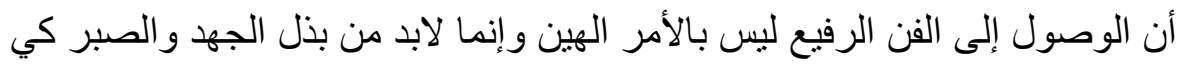

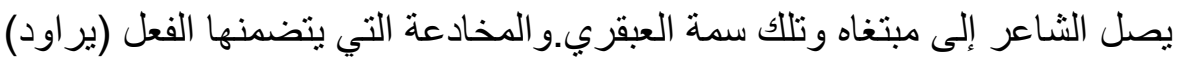

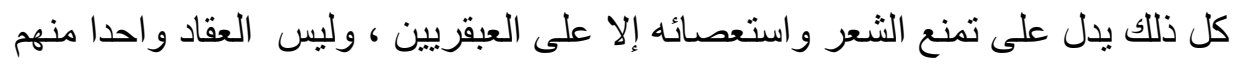

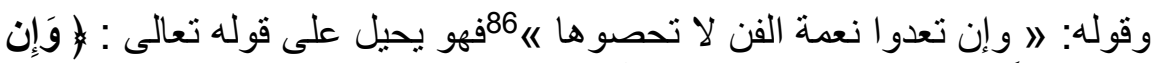

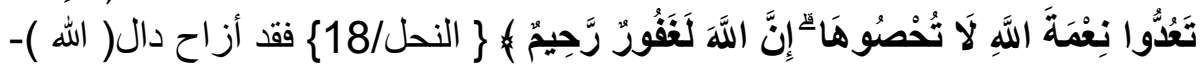

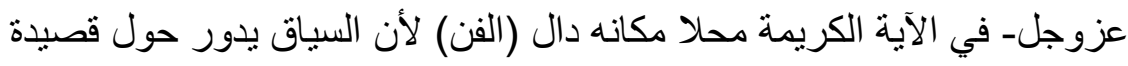

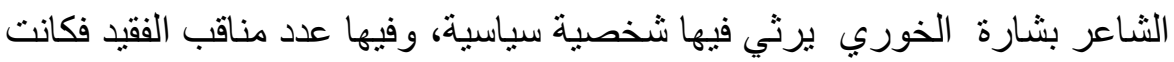

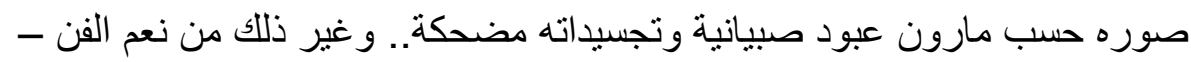

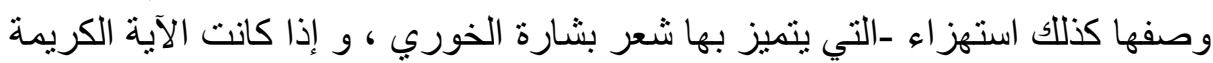

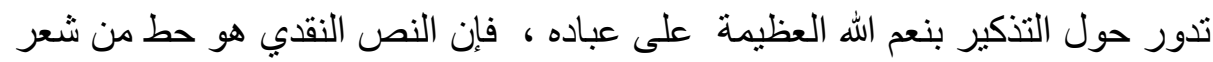

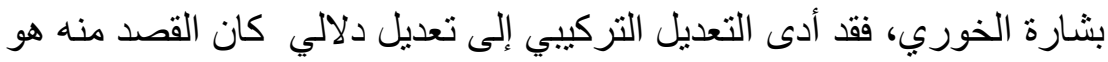
السخرية . 
وفي نص آخر يقول فيه : لا لا يغضب العقاد أن نصارحه بما في نفسنا، فهذا

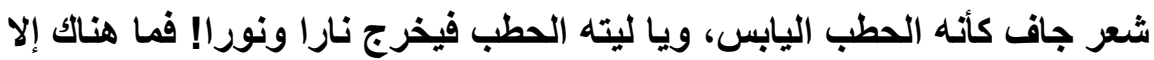

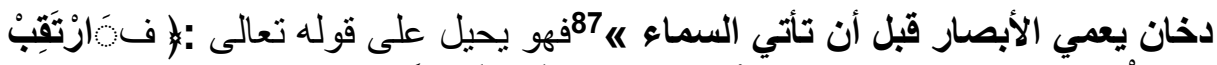

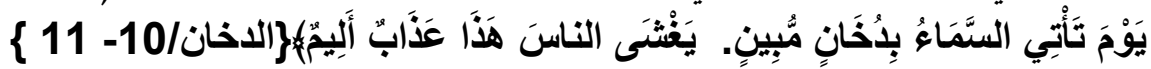

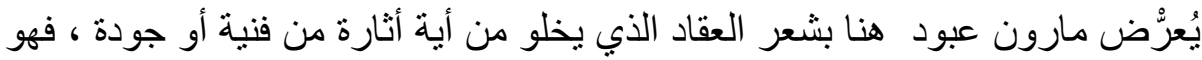

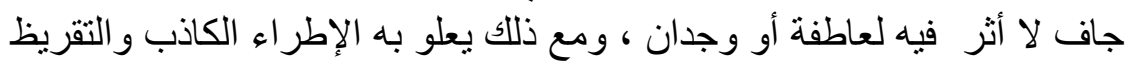

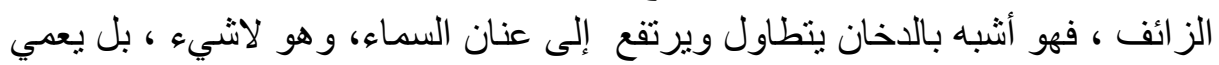

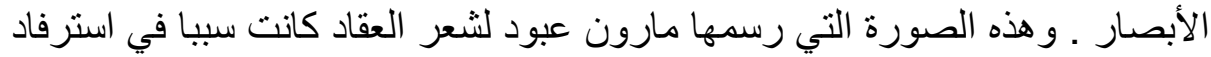

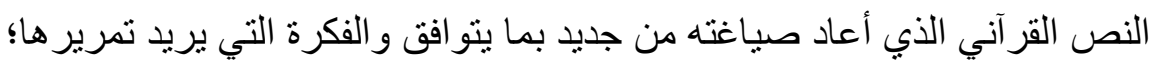
و تللك خاصية التناص الإحالي الذي لا هو إعادة صياغة التناص ، و وتفكيك بناه التركيبية

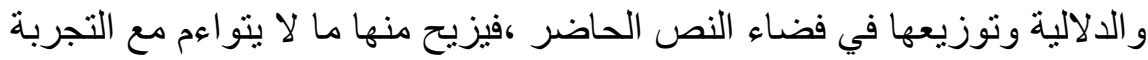

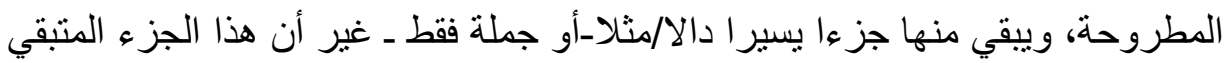

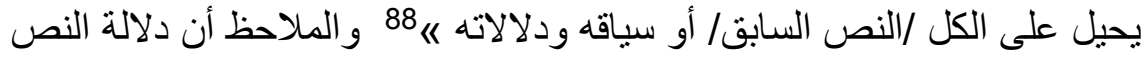

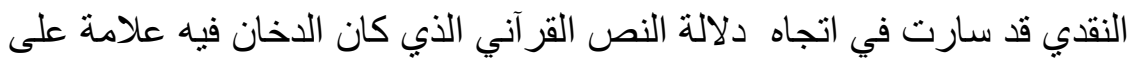

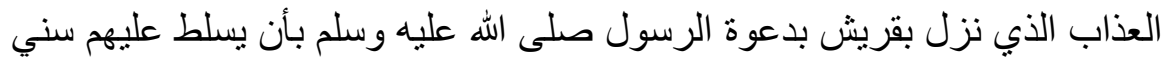

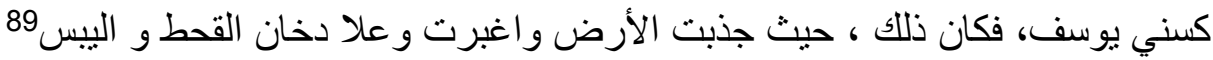
وكذلك الاخان المراد به في النص النقدي هو علامة على جذب قريحة العان العقاد الثعرية

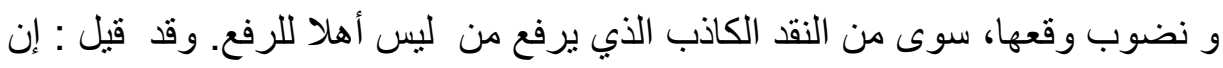

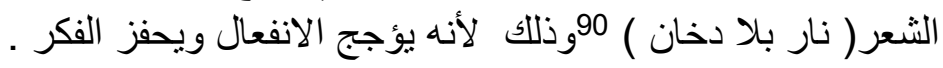

ويقول أيضا : وإن يعجبني في العقاد شيء فهو هذا الإيمان المكين بفنه، إنه

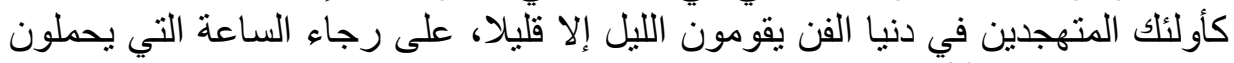
فيها كتابهم بيمينهم 91

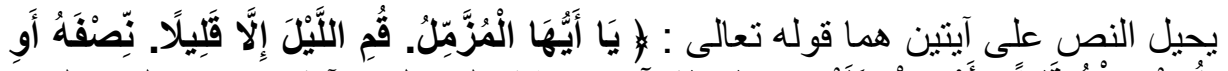

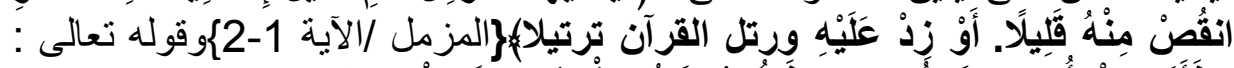

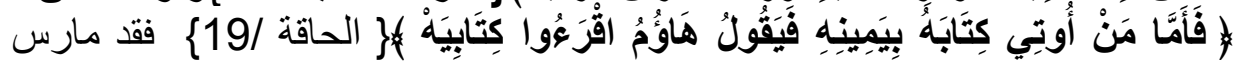

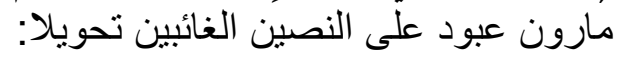
- تركيبيا: في الأول : متهجدين بدلا من المزمل. و يقومون بدلا من قم .

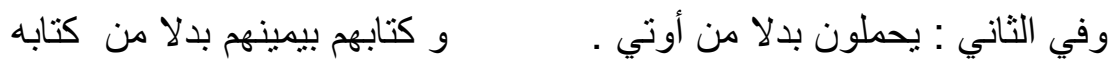

-و انزياحا دلاليا بحيث أن التهجد وقيام الليل ليس تعبدا لله ورجاء رحمته، و طمعا في الإني

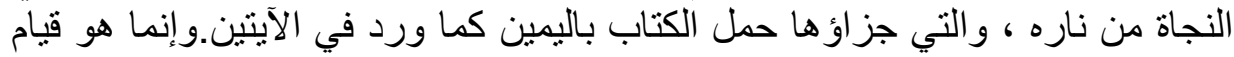

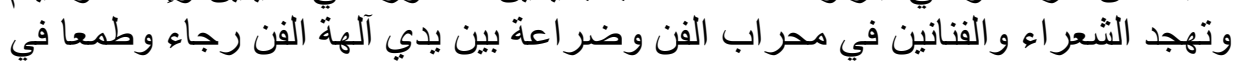
امتلاك ناصيته .

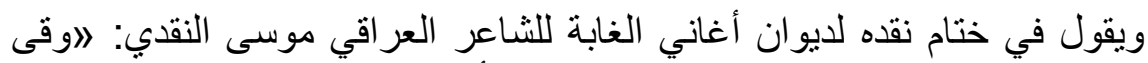

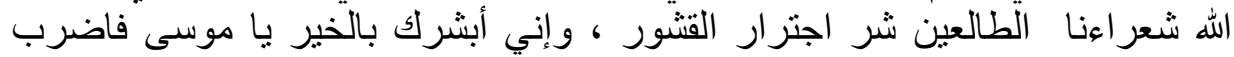

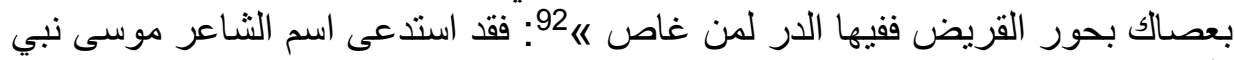

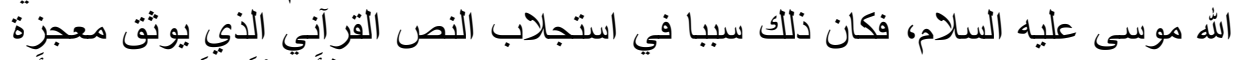

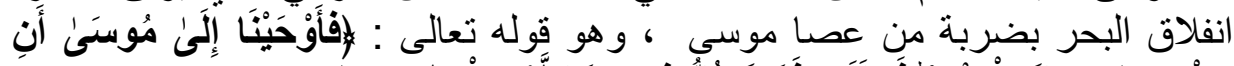

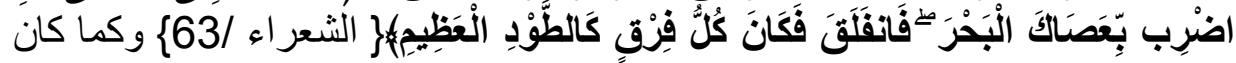


عبور البحر نجاة وحياة لموسى عليه السلام ومن كان معه. فإن في بحور الثُعر حياة

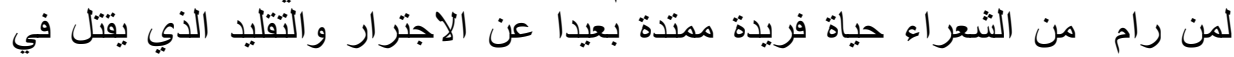

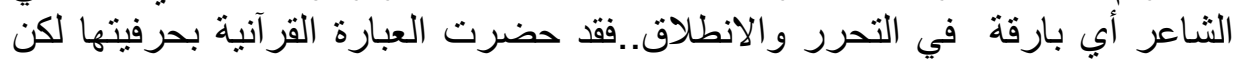

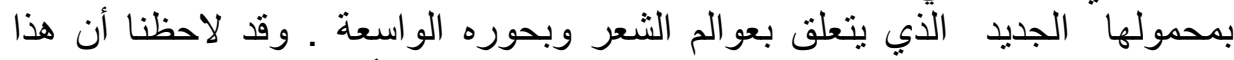
التتاص نم بعفوية ودون تقصد من مارون عبود، تماما كأغلب تناصاته التي كانت انثيالا عفويا لما بهجع في ذاكرنه.

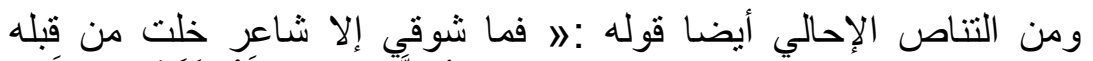

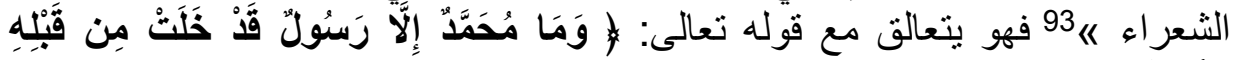

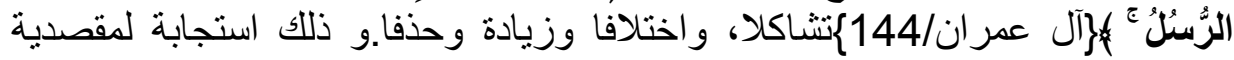

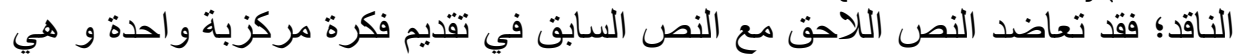

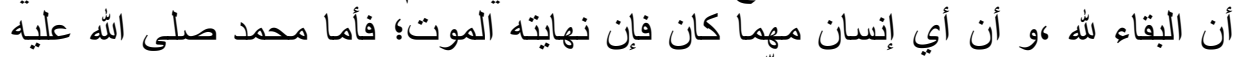

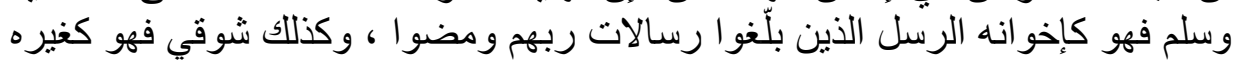

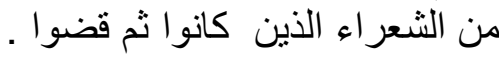

و مما سبق من أمثلة التناص الإحالي لاحظنا أن النص الغائب ـفي هذه الحالة

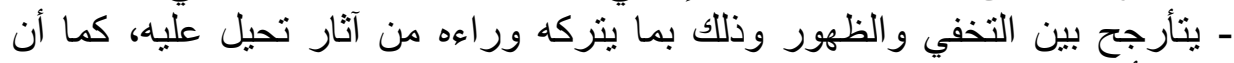

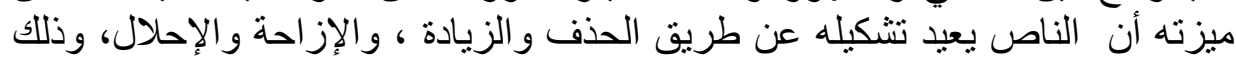

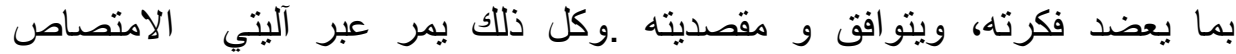

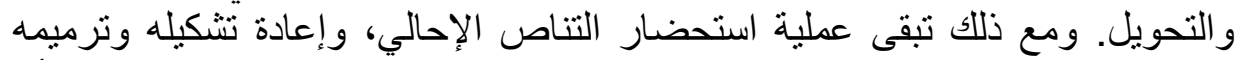

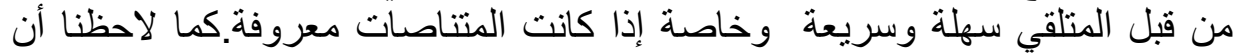
هذه التناصات يتحكم فيها منطق العفوية والسجية ،ولذلك كانت في أنم الانسجام مع لاحن

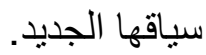

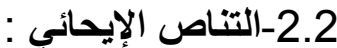

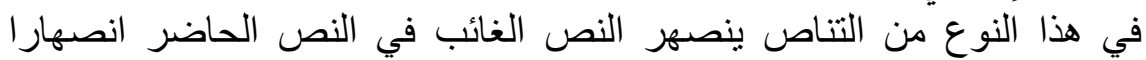

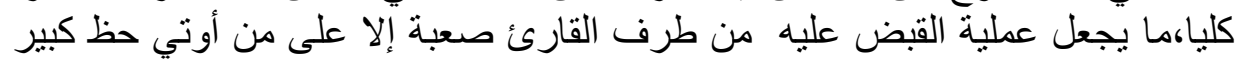

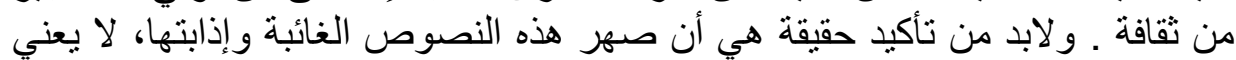

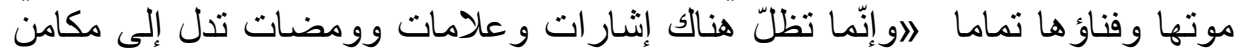

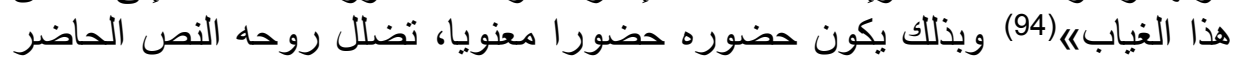

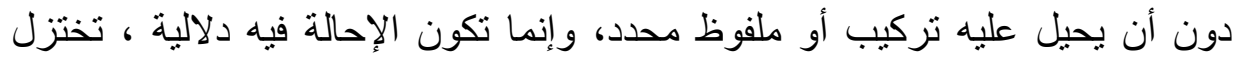
مضامين المتناص بشكل مكثف غير ظاهر ، لكنها تتعالق معه 95 أبي أن التناص

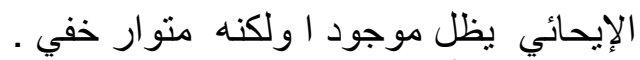

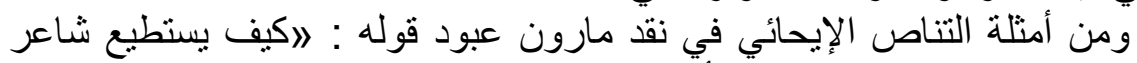

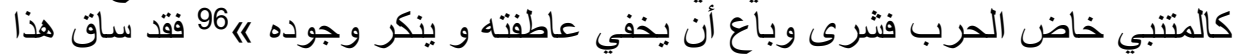

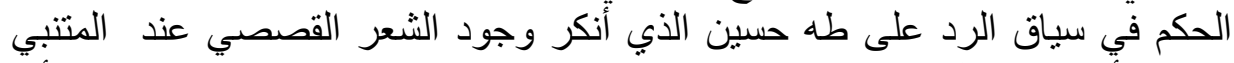

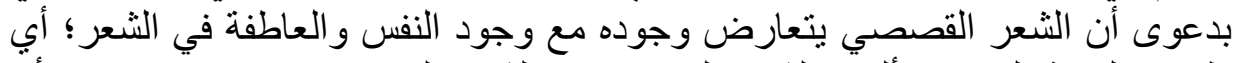

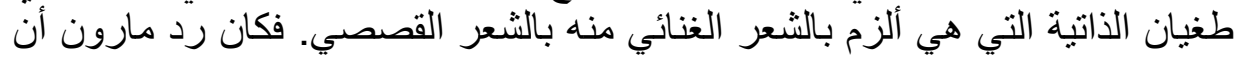

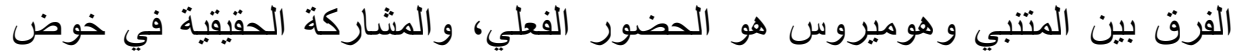

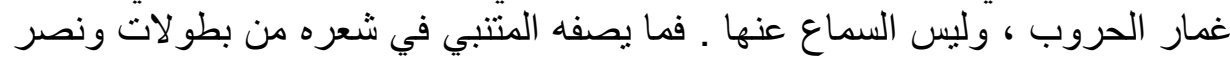

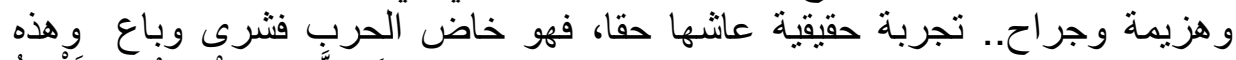

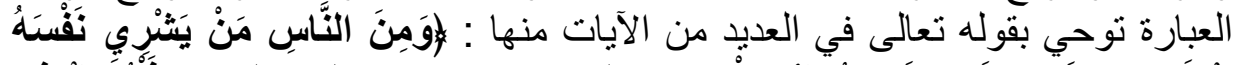

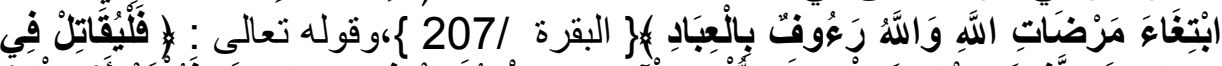

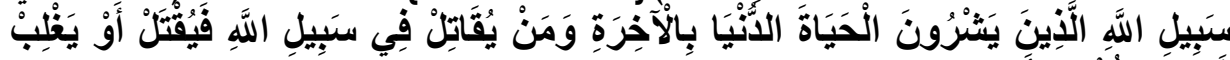

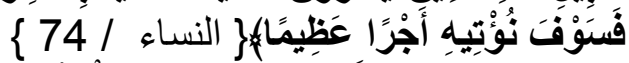

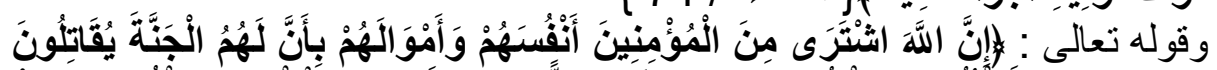

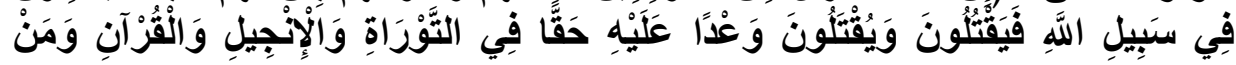




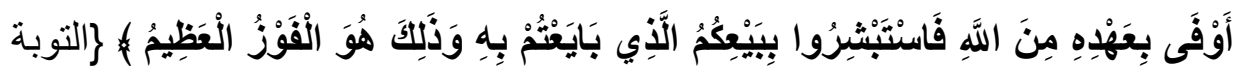

جاء في كثاف الزمخشري أن يشري نفسه بمعنى يبيعها (97 ) ، ويشرون بمعنى

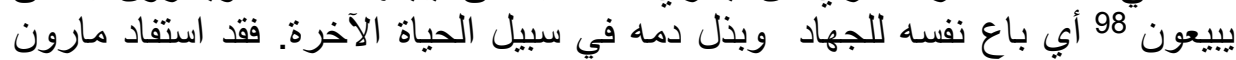

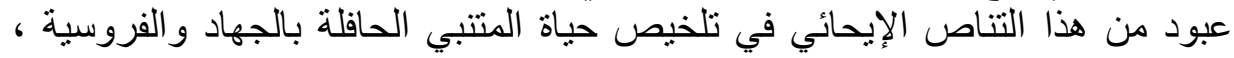

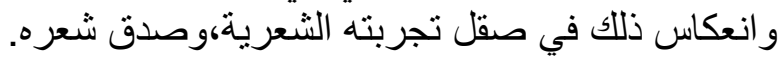

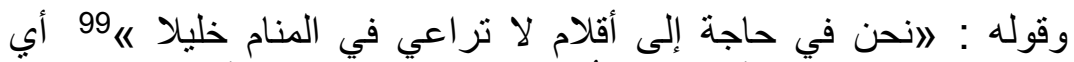

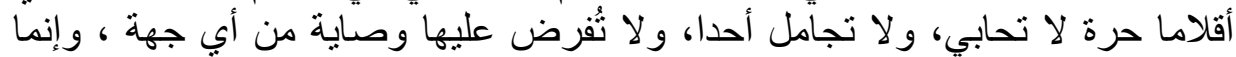

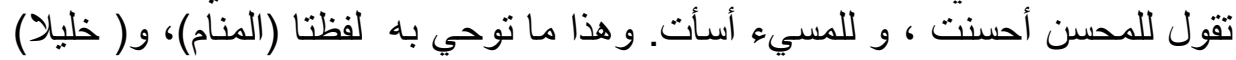

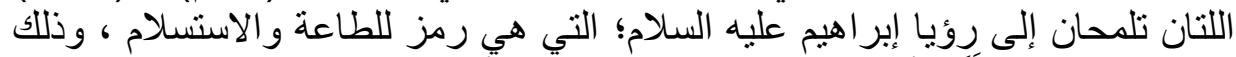

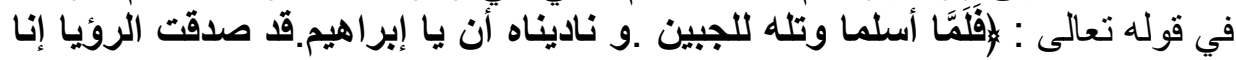

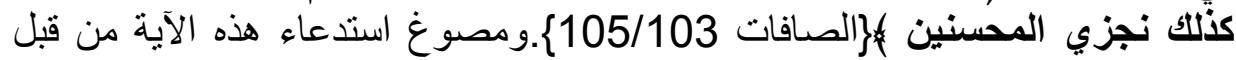

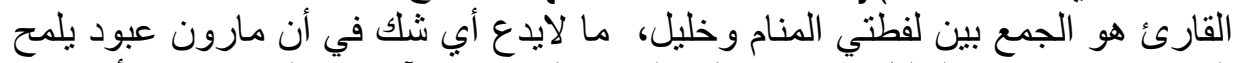

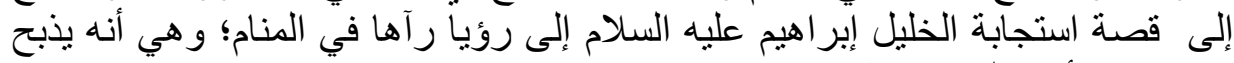

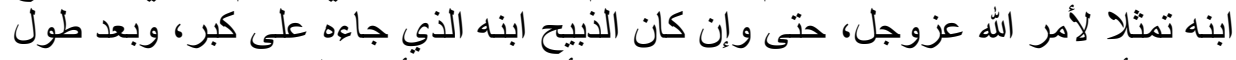

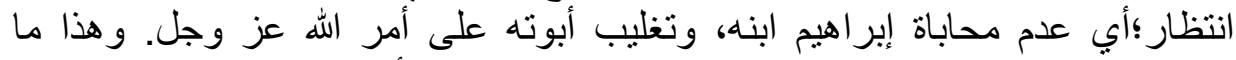

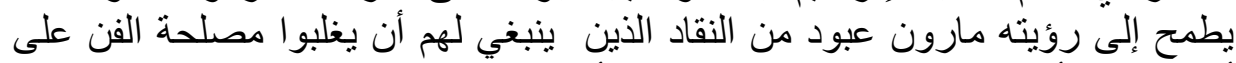

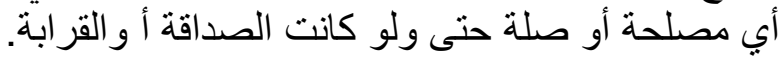

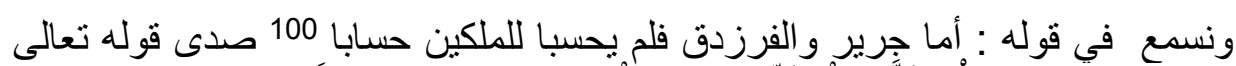

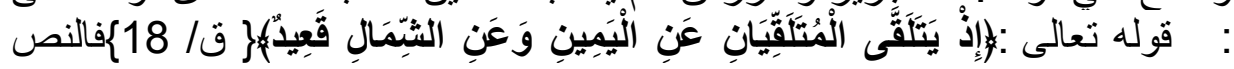

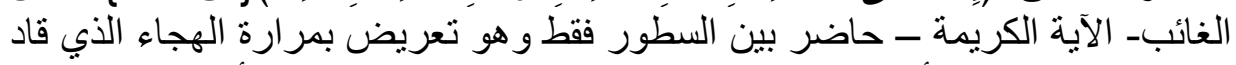

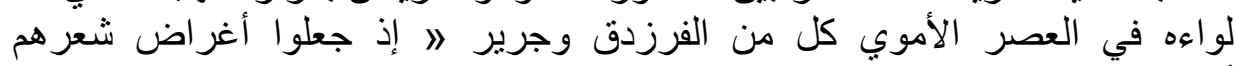
أعر اض قبائلهم هـ 101دون حساب ليوم لئ الحساب .

وكذلك في قوله : الافلو كان في أقوال الشعر اء خير ما قال عنهم الكتاب الكريم ما قال

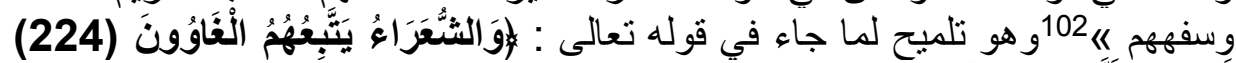

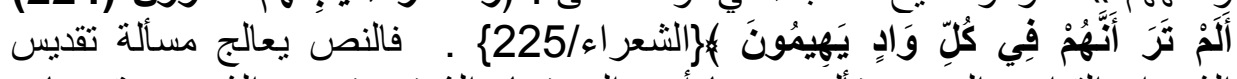

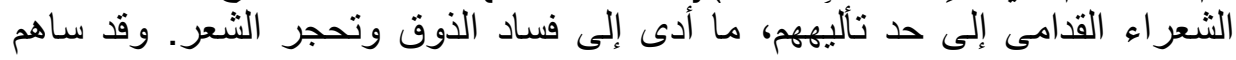

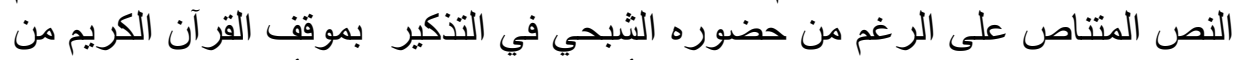

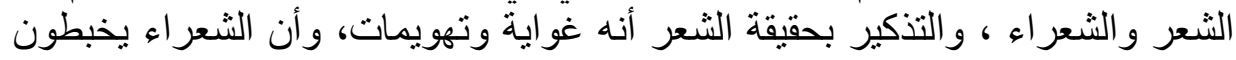

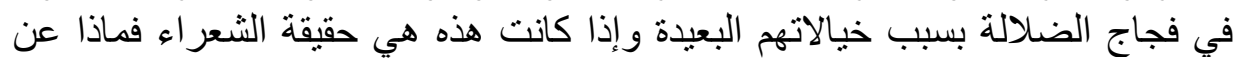

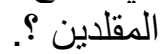

كذللك يقول: لا فإنني لم أشعر بشيء من الثعر في هذه القصيدة، أرى مصر في سني

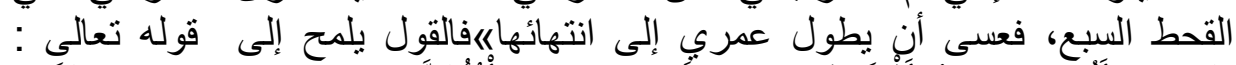

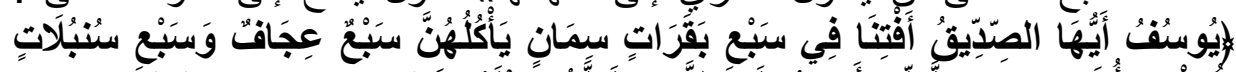

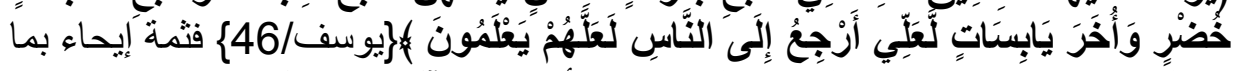

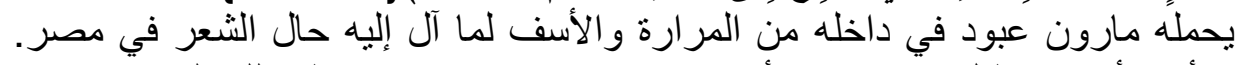

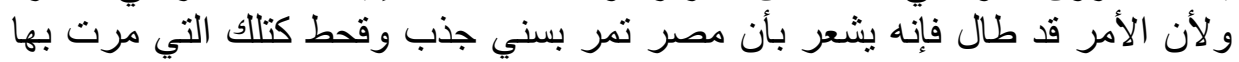

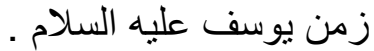

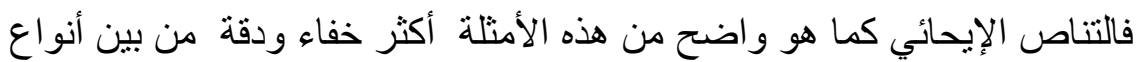

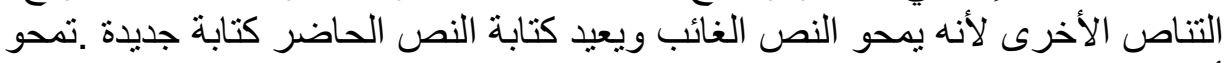

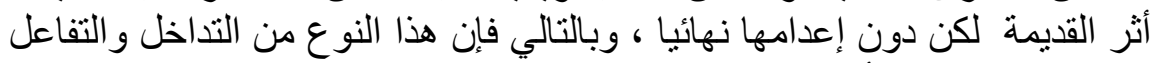

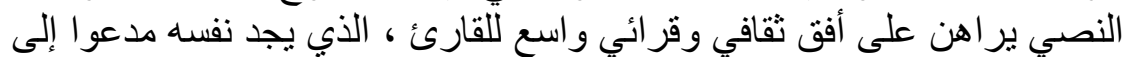

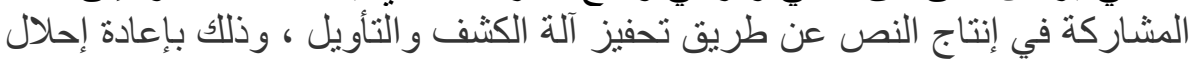




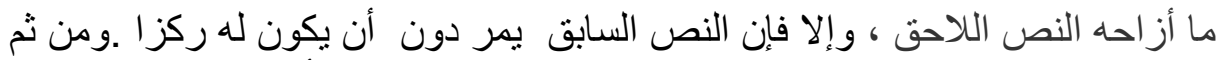

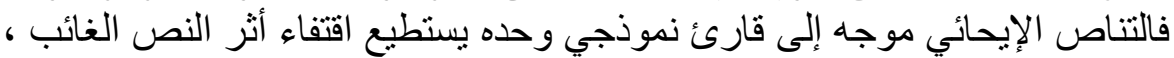

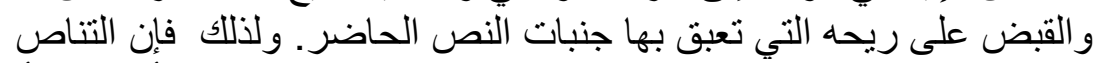

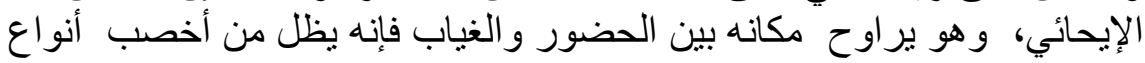

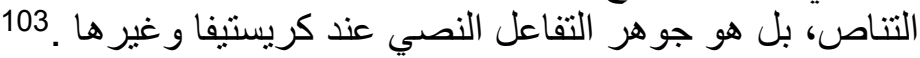

3- - 2 - التناص العكسي:

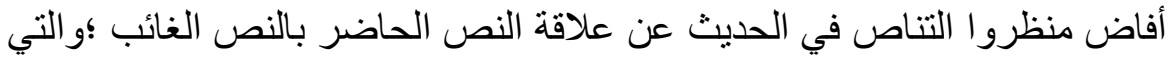

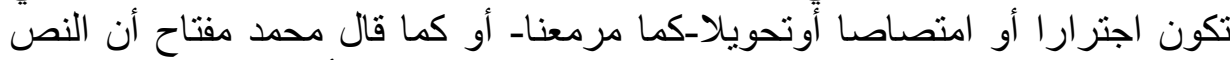

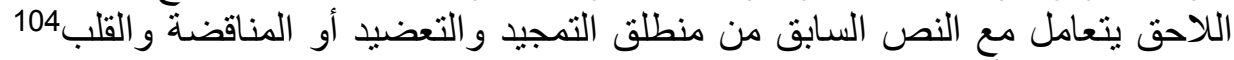

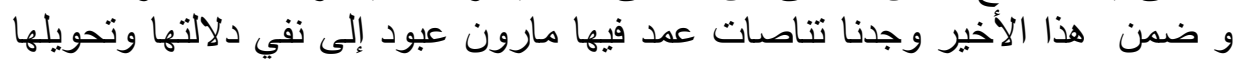

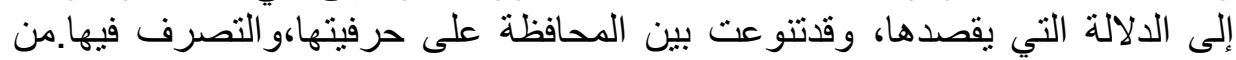

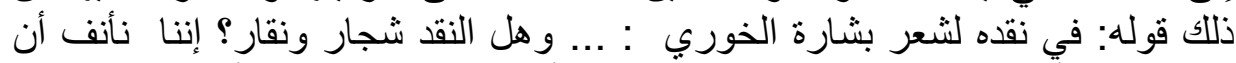

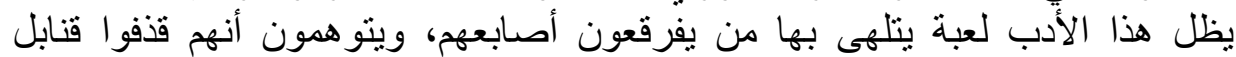

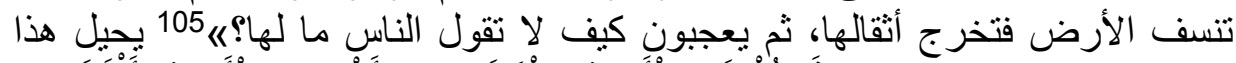

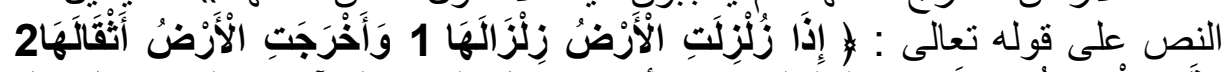

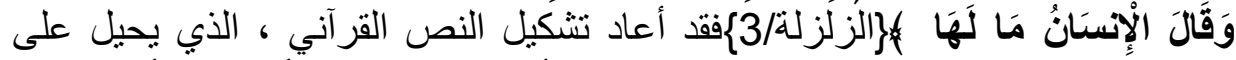

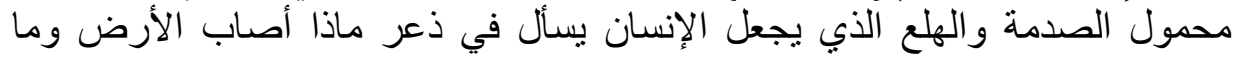

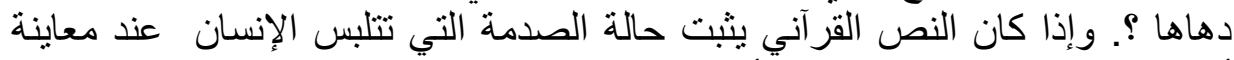

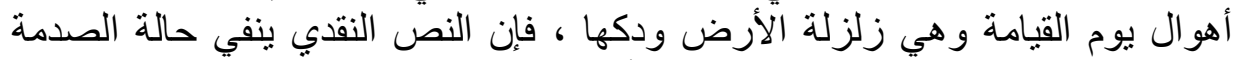

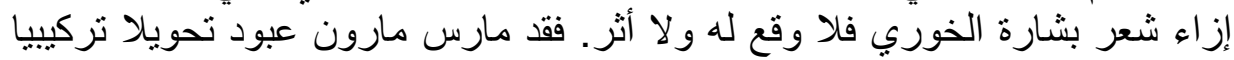

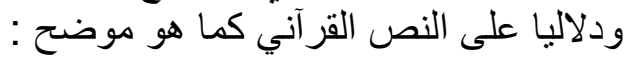

$$
\begin{aligned}
& \text { قال(في النص القرآني ) - ل لا يقول (في النص النقدي ) }
\end{aligned}
$$

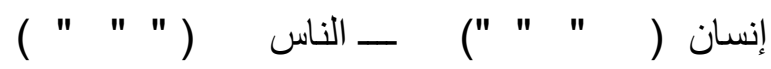

$$
\begin{aligned}
& \text { زلزلة القيامة ( " " " ) - قـنابل (قصائد) ( " " " ) }
\end{aligned}
$$

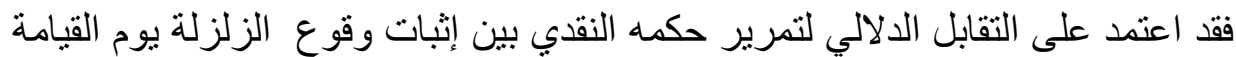

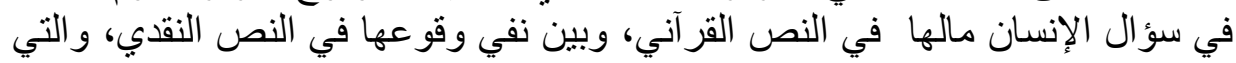

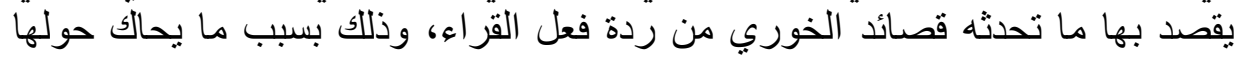

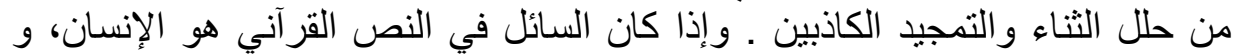

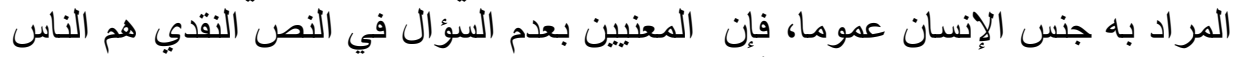

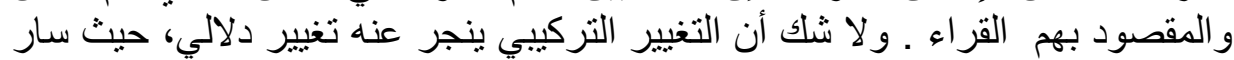

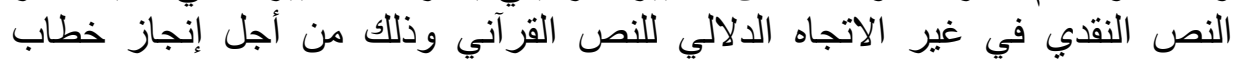

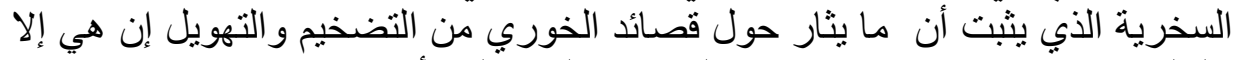

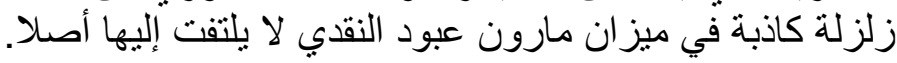

وقال أيضا : الشعر إلياس أبو شبكة وليد حالات نفسانية. كان ذا نفس متقدة الانة

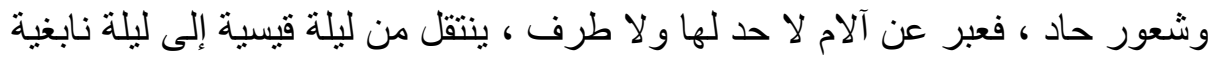

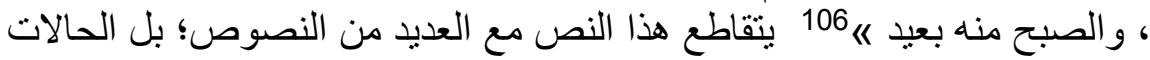

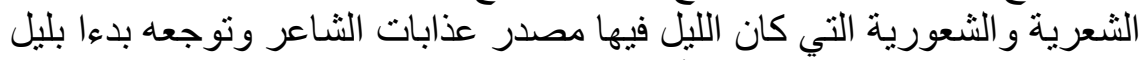

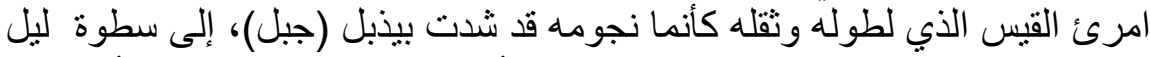

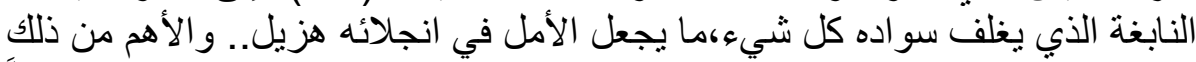

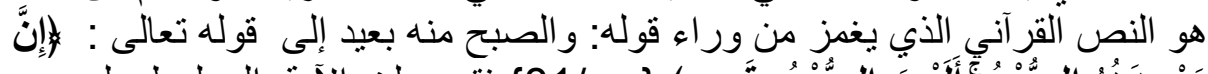

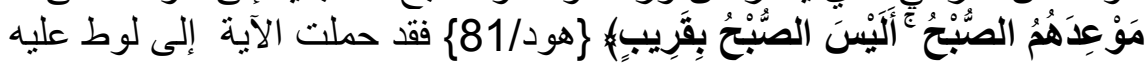


السلام بشرى عقاب قومه، وقد استعجل حلول العقاب بهر ، فأمهلته الملائكة بقولها:

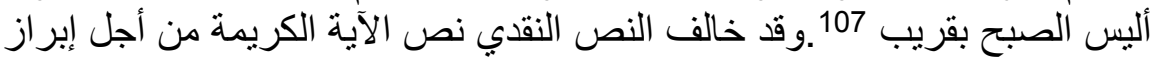

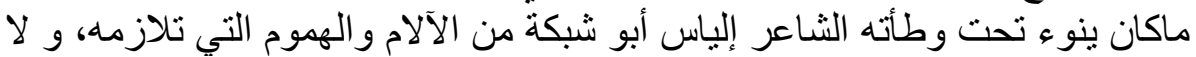

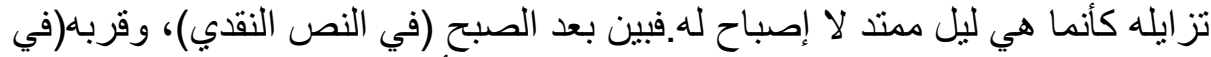

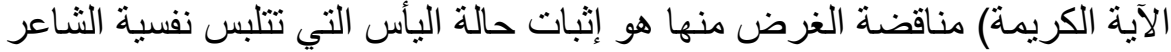
إلباس أبو شبكة وشعره. وقد ساهم التناص العكسي في تعميق هذه الحالة .

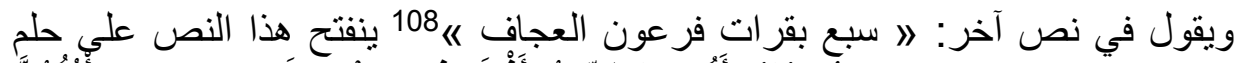

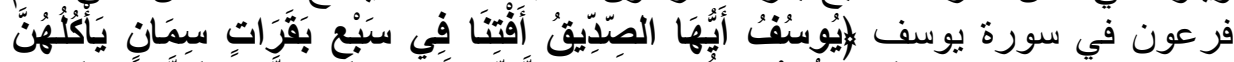

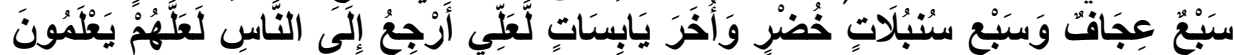

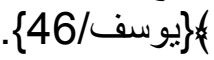

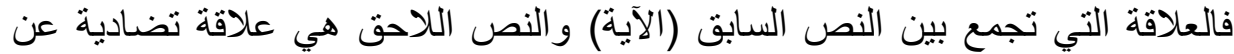

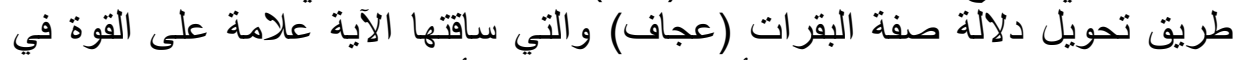

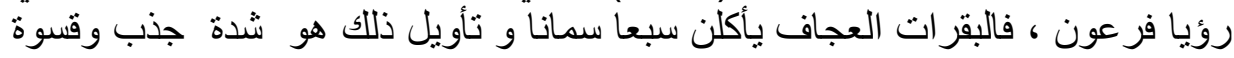

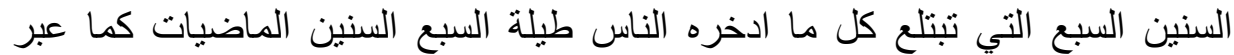

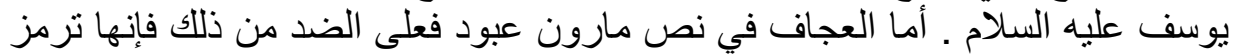

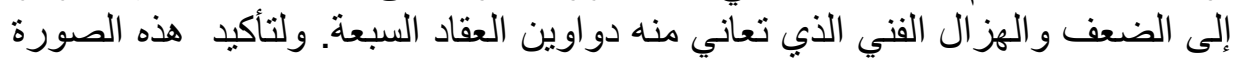

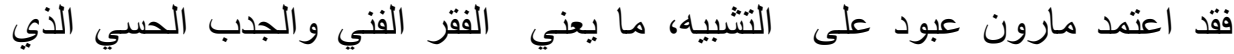

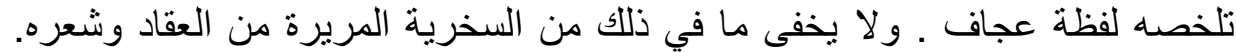

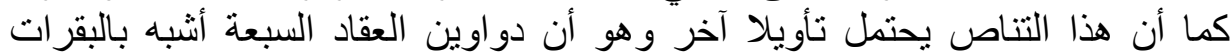

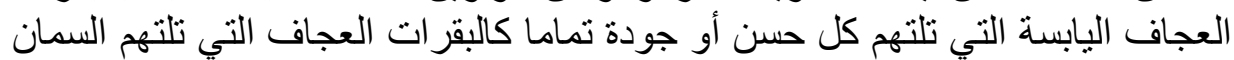

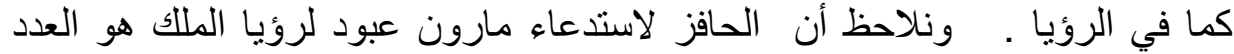

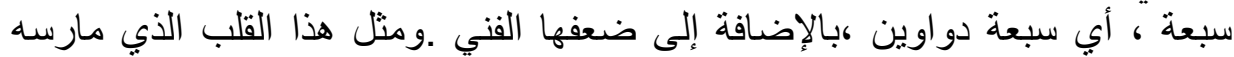

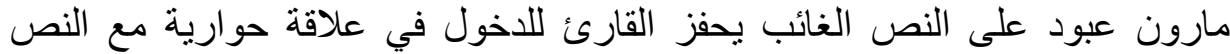

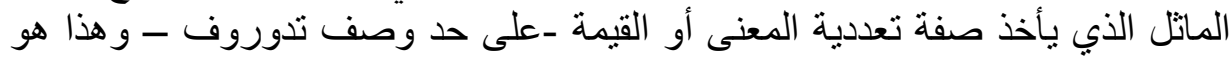
مكمن فاعلية التناص وحيويته .

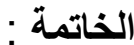

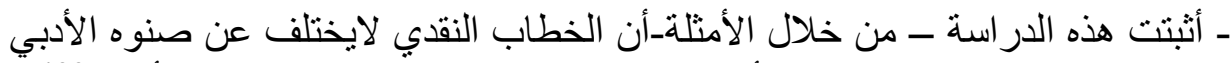

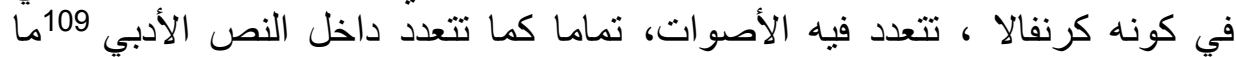
يسمح بالقول بوجود تناصية نقدية .

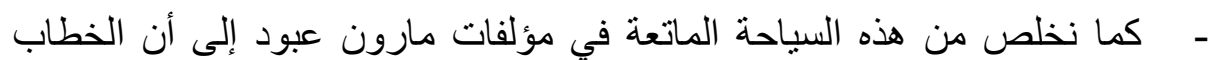

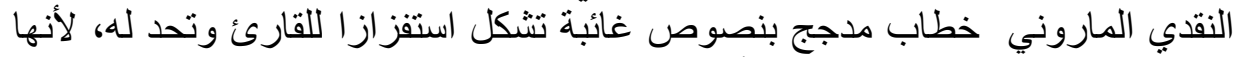

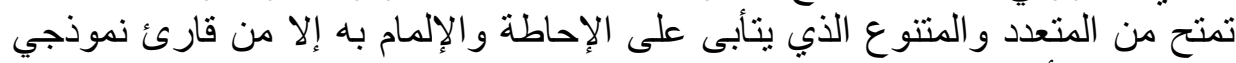

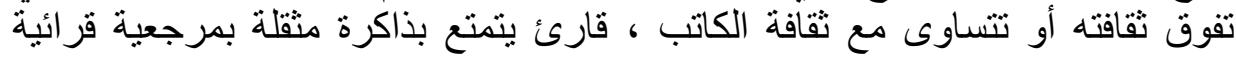

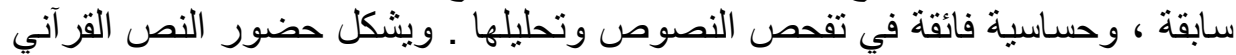

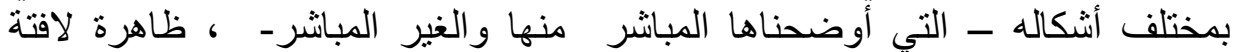

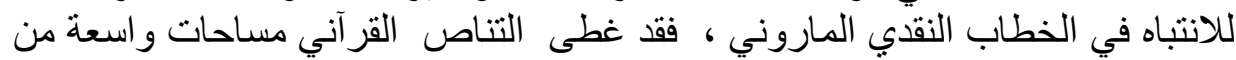

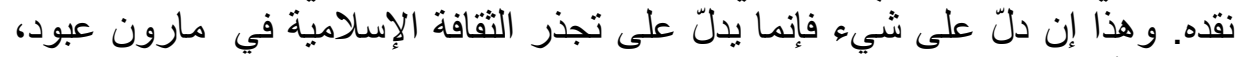

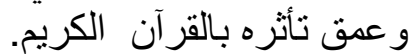

-تراوح استثمار مارون عبود للنص القرآني بين الاجترار والامتصاص والتحويل

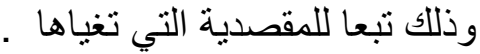




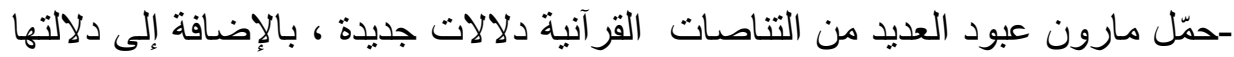

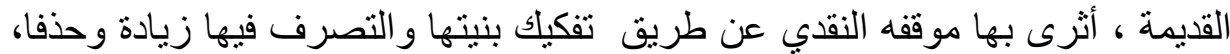

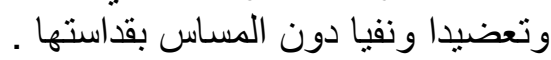
ـكانت تناصاته سواء الصريحة، أوالخفية في غاية الامتز اج والانسجام مع السياقات الجديدة التي استنبتها فيها -كانت مختلف التناصات وسيلة لتمرير نقده الساخر الذي يشكل تيمة قارة في كتاباته، و التي تعكس الحس الفكاهي لديه. -كانت العديد من تناصاته وليدة الانثيال العفوي و التلقائية . -ثر اء الخطاب النقدي لمارون عبود وهذا ب بسبب التوالد اللامحدود الذي يمنحه التناص

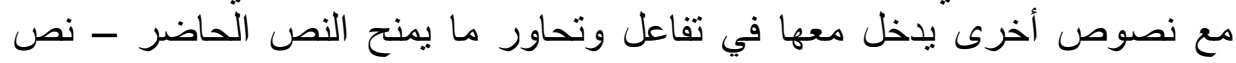

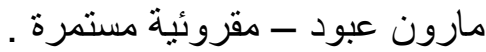

\section{هوامش البحث}

عبد الفتاح كليطو ـ المقامات السرد والأنساق الثقافية ، ترجمة عبد الكبير الشرقاوي ، دار

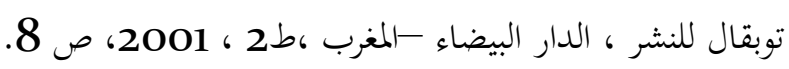

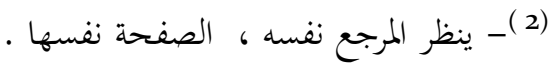

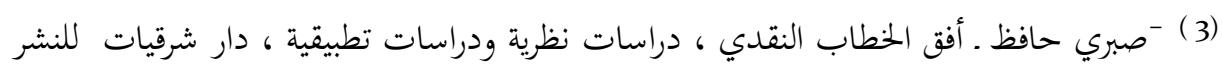

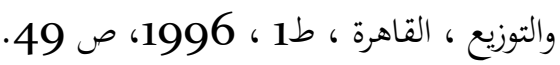

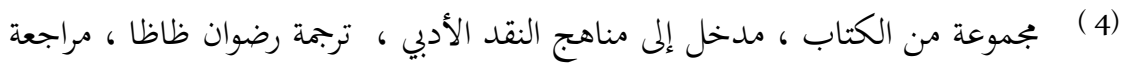

المنصف الشنوفي ، عالم المعرفة ، سلسلة كتب ثقافية شهرية يصدرها المجلس الوطني للثقافة والفنون

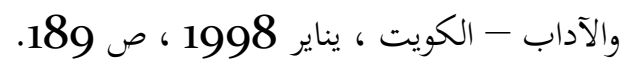

نقلا عن صلاح فضل ، بلاعة الخطاب وعلم النص ، عالم المعرفة ، سلسلة كتب ثنافير هافية

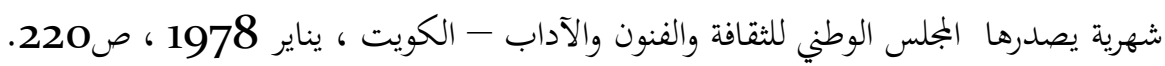

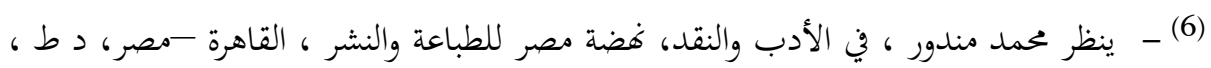

د ت ، 61 (7)

(7) - محمد مندور، النقد المنهجي عند العرب ، ومنهج البحث في الأدب واللغة،دار فضة مصر

$$
\text { للطباعة والنشر،دط، دت ،ص400. }
$$

ينظر ، تزيفطان تودوروف ، الشعرية، ترجمة شكري المبخوت ،ورجاء بن سلامة ، دار توبقال

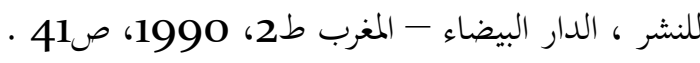

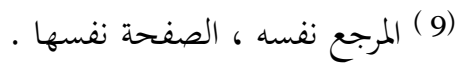

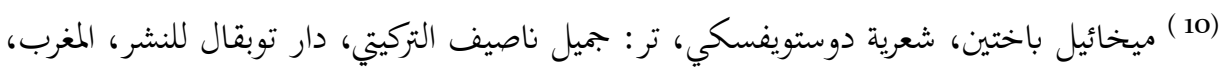


(11) ينظر ، تزيفيطان تدوروف ، ميخائيل باختين ، المبدأ الحواري، ترجمة فخري صالح، المؤسسة

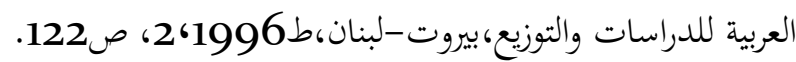
(12) ينظر المرجع نفسه ، الصفحة نفسها.

(13) عبد الله الغذامي ،الخطيئة والتكفير ، من البنيوية إلى التشريحية ، نظرية وتطبيق ، المركز الثقافي

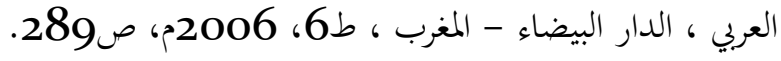

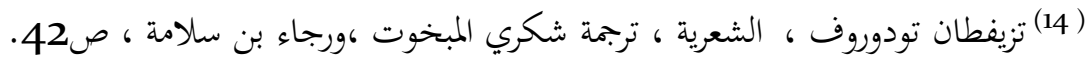

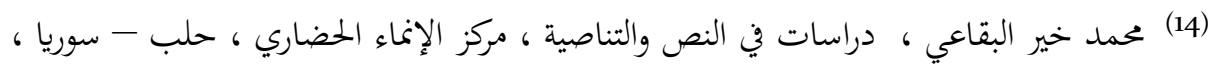

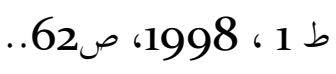

(16) ميخائيل باختين : الخطاب الروائي ، ترجمة : محمد برادة ، ط1 ،دار الفكر للدراسات و النشر و

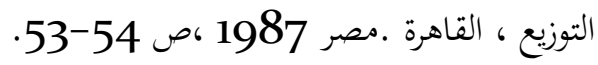

(17) ينظر، جان ايف تادييه ، النقد الأدبي في القرن العشرين ، ترجمة منذر عياشي ، مركز الإنماء

$$
\text { الحضاري ، ط1، 1894، ص134 (134. }
$$

(18) جوليا كريستيفا ، علم النص ، ترجمة فريد الزاهي ، دار توبقال ، الدار البيضاء -المغرب ، ط23،

$$
\text { 21997 }
$$

(19 ينظر ، رولان بارت ، لذة النص، ترجمة منذر عياشي، مركز الإنماء الحضاري ، ط2، 2002،

ص104

$$
\text { (20) جوليا كريستيفا ، علم النص ، ترجمة فريد الزاهي، ص21) }
$$

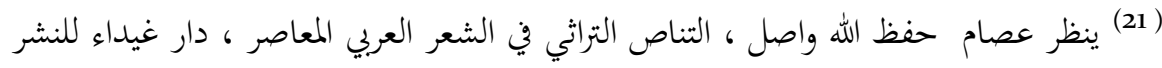

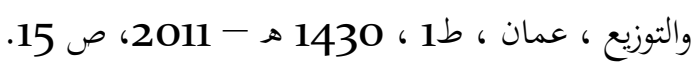

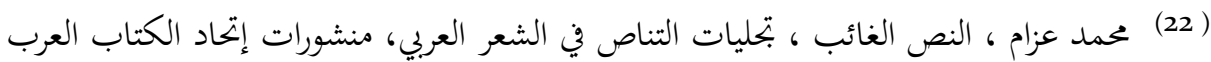

$$
\text { - دمشق د ط، 2001، ص29. }
$$

(23) خليل الموسى ، قراءات في الشعر العربي المعاصر ، موقع اتحاد الكتّاب العرب على شبكة

$$
\text { الإنترنت }
$$

.53 صww.awu-dam.com

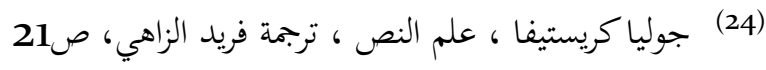

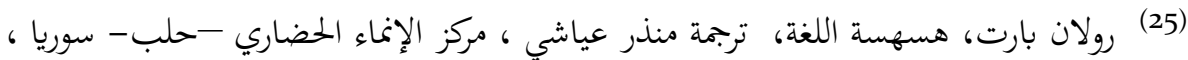

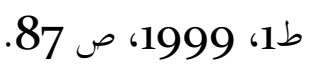$$
\text { (26) المرحع نفسه ،ص 199، ص } 90
$$$$
\text { (27) المرجع نقسه ،ص } 80 .
$$ 
(28) أحمد الزعبي ، التناص نظريا وتطبيقيا، مقدمة نظرية مع دراسة تطبيقية للتناص في رواية رؤيا

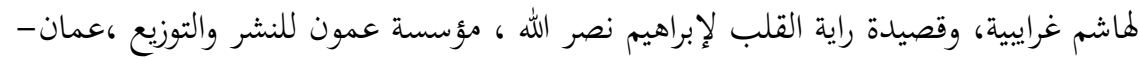
الأردن، ط2، 2000، 2000، ص ص 13. (29) ينظر خليل الموسى ، قراءات في الشعر العربي المعاصر ، ص2000، ص233.

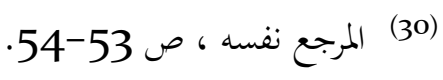

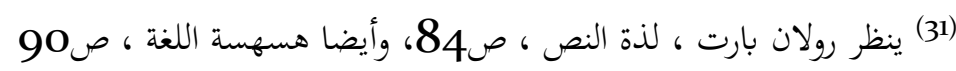

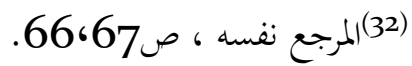

(33) سعيد يقطين ، من النص إلى النص المترابط : مدخل إلى جماليات الإبداع التفاعلي ، المركز

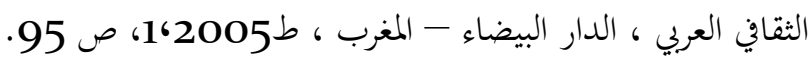

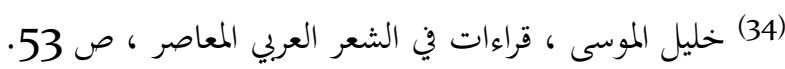

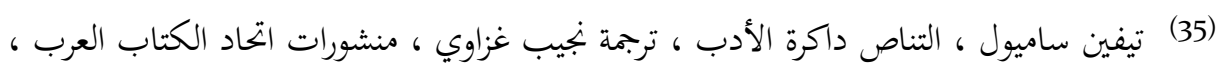
دمشق ، دط ، 2007، ص20. (36) ينظر ، جيرار جنيت، مدخل إلى جامع النص ، ترجمة عبد الرحمن أيوب، دار الشؤون الثقافية

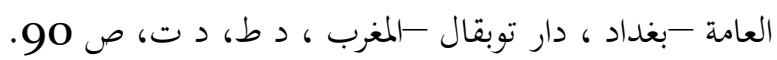

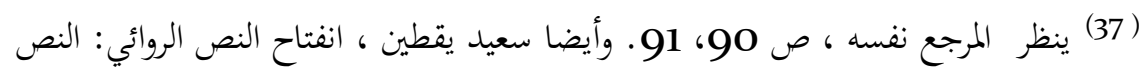

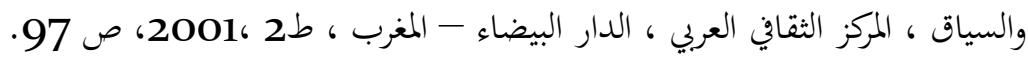

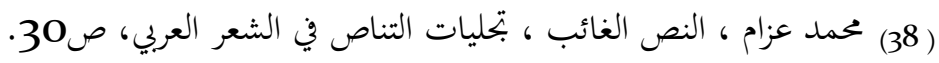

(39) ينظر وليم راي ، المعنى الأدبي من الظاهراتية إلى التفكيكية ، ترجمة يونيل يوسف عزيز ، دار

المأمون للترجمة والنشر، ط1، 1987، ص ونسي رائ 149، وأيضا أحمد الزعبي ، التناص نظريا وتطبيقيا،

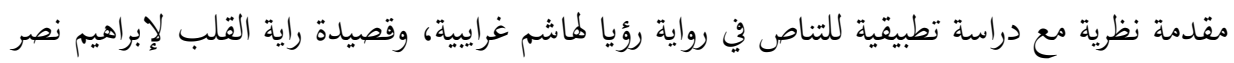
الله، ص16. (16. (40) ابن رشيق القيرواني ، العمدة في محاسن الشعر وآدابه ونقده ، المكتبة العصرية ، صيدا- بيروت

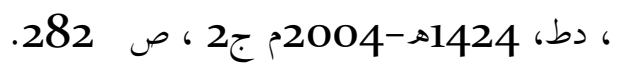

(41) أبو علي محمد الحاتمي ، حلية المحاضرة في صناعة الشعر. تحقيق جعفر الكتاني ، دار الرشيد

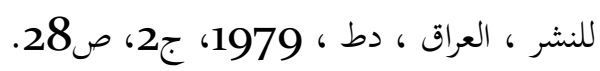

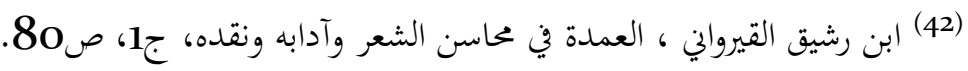

أورد صاحب جدلية التعالق النصي بين السرقات الأدبية والتناص مقاربة اصطلاحية ،

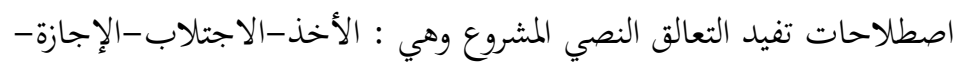

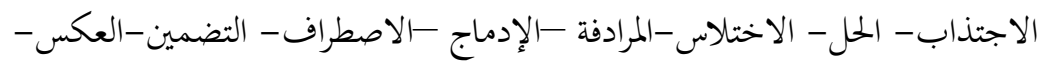
العقد- الاقتباس-الاستلحاق-التلفيق-الإلمام- التمليط- الاهتدام-المواردة -المناقضة. 


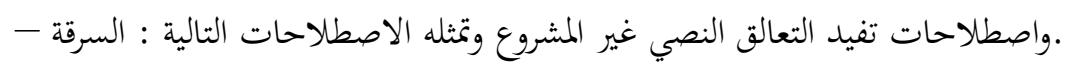

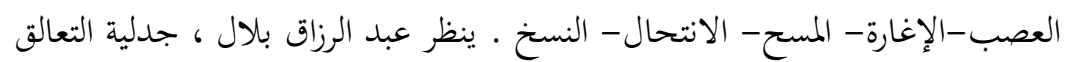

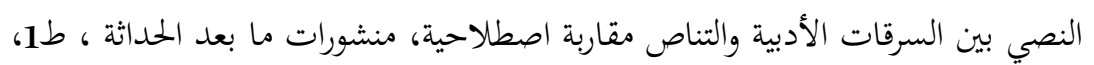

$$
\text { 2009، ص409 }
$$

(43) ينظر ، غلة فيصل الأحمدي ، التفاعل النصي، التناصية النظرية والمنهج ، الهيئة العامة لقصور

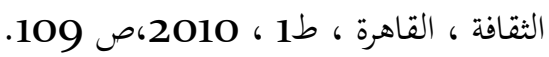

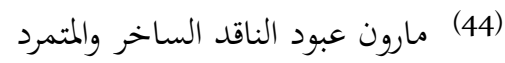

، 22:35.30.09.09 http://dreamsway.ahlamontada.net حنا الفاخوري،الجامع في تاريخ الأدب العربي، ، دار الجيل- بيروت-لبنان، دط، دت ، ص325.

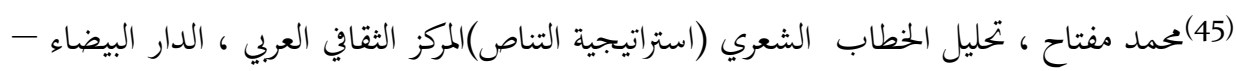

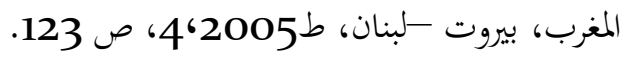

(46) أبو منصور،عبد الملك الثعالبي الاقتباس من القروت صنآن الكريم ، تحقيق: إبتسام مرهون

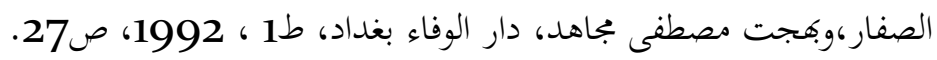

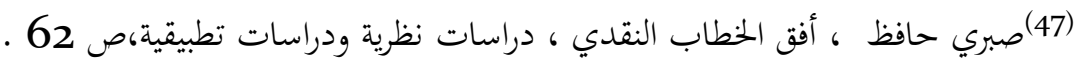

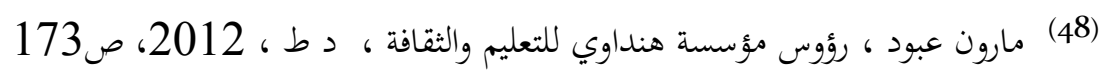

$$
\begin{aligned}
& \text { (49)يقول في ذلك : عشت يا بني، عشت يا خير صبي ولدته أمه في ارجبِ } \\
& \text { فهتفنا واسمُهُ محمدُ أيها التاريخ لا تستغربِ }
\end{aligned}
$$

خَفِّفِ الدهشةَ واخشعْ إن رأيتَ ابنَ مارونٍ سميّاً للنبي

$$
\text { أمّه ما ولَدتنُهُ مسلماً أو مسيحياً ولكن عربي }
$$

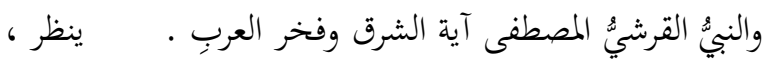

https://ar.wikipedia.org/wiki

(50)مارون عبود ، نقدات عابر ، ضمن كتاب الأعمال الكاملة ، مج5، د ط ، د ت ، ص 13.

(51) مارون عبود ، مجددون وبجترون ، مؤسسة هنداوي للتعليم والثقافة ، د ط ، 2012 ، ص 14

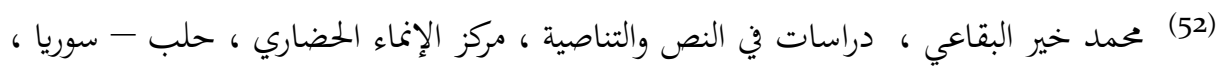

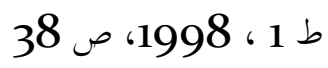
(53) ابن منظور ، لسان العرب ، دار صادر ، بيروت ط3، 2004، ج13،ص9،مادة (قبس).

$$
\begin{aligned}
& \text { (54) تيفين ساميول ، التناص ذاكرة الأدب ، ترجمة نجيب غزاوي ص22) }
\end{aligned}
$$

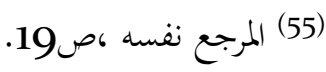

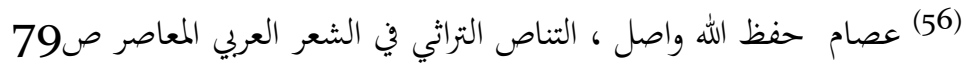


(57) الخطيب القزويني، الإيضاح في علوم البلاغة المعاني والبيان والبديع ، دار الكتب العلمية -

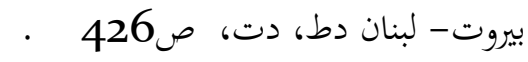

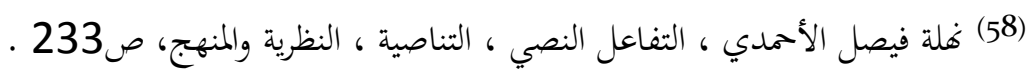
(59) صبري حافظ ، أفق الخطاب النقدي ، دراسات نظرية ودراسات تطبيقية، 62 ، 62 ،

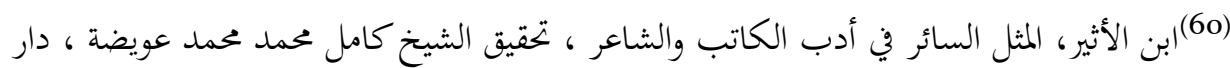

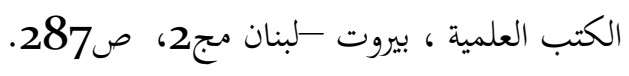

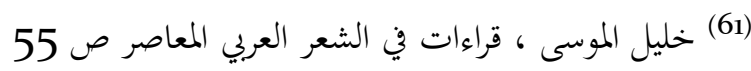

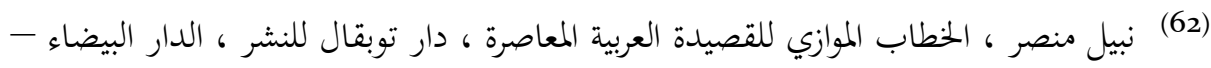

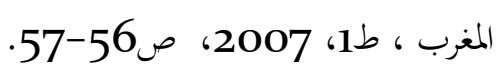

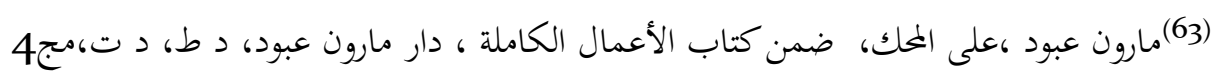

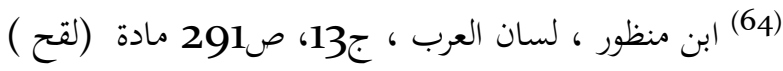

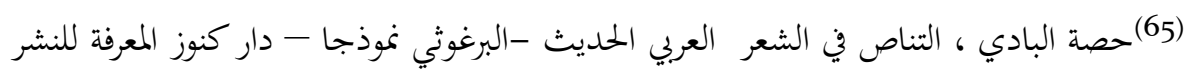

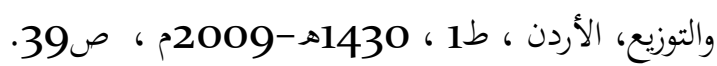

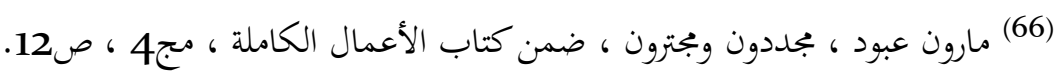

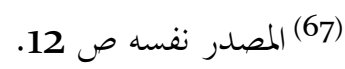

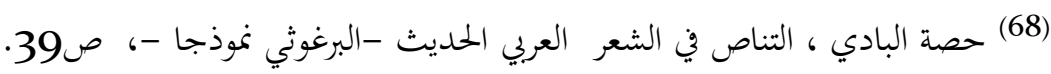

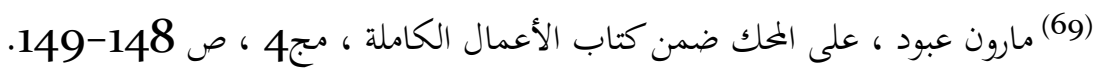

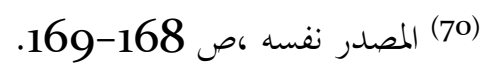

(71) ينظر : ابن كثير ، تفسر القرآن العظيم ، دار الدعوة الإسلامية ، مصر ، ط1، 1424هـ-

$$
\text { 2004 2004م، ج4، كن } 697
$$

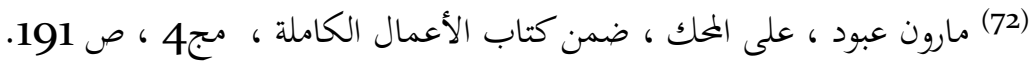

$$
150 \text { (73) المصدر نفسه ، } 150
$$

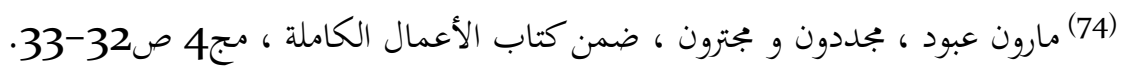

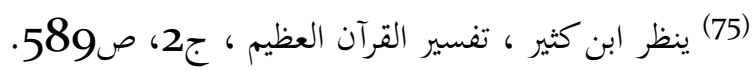

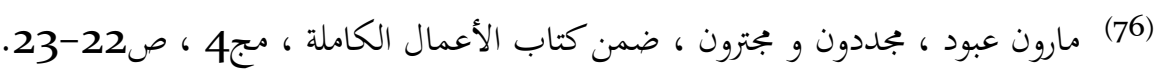

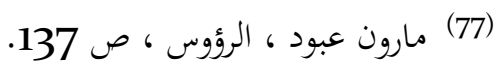

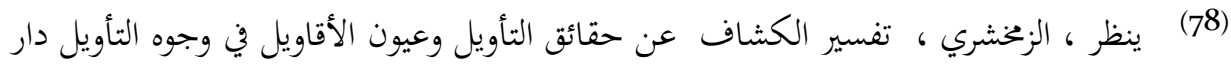

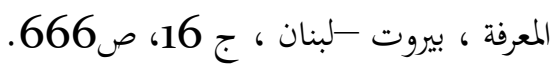

(79) مارون عبود ، رؤوس ص 158-159. ينظر أيضا نقدات عابر ، ضمن الأعمال الكاملة

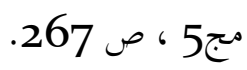

(80) مارون عبود، على المحك ، ضمن كتاب الأعمال الكاملة ، مج4 ، ص 197. 
(81) عصام حفظ الله واصل ، التناص التراثي في الشعر العربي المعاصر ، ص105 عادمان

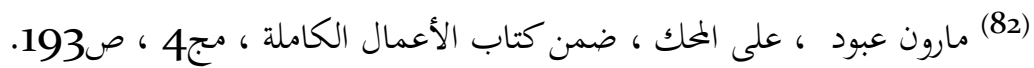

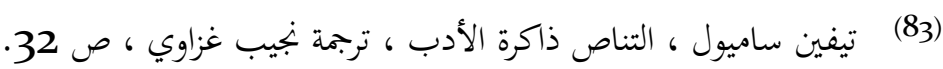

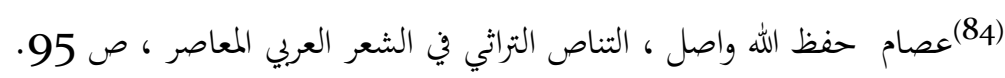

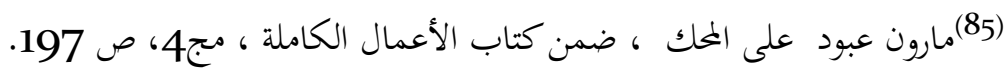

$$
\text { (86) المصدر نفسه ، ص ص المصدر نفسه ، ص } 158 .
$$

(88)(عصام حفظ الله واصل ، التناص التراثي في الشعر العربي المعاصر ،،ص 131 ، 131.

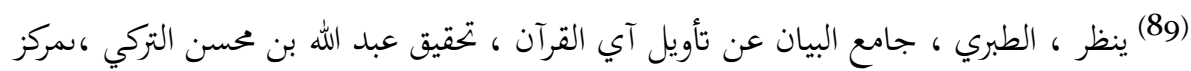

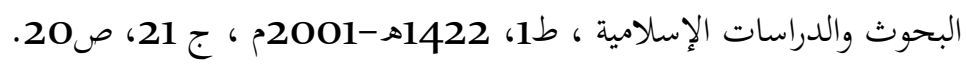

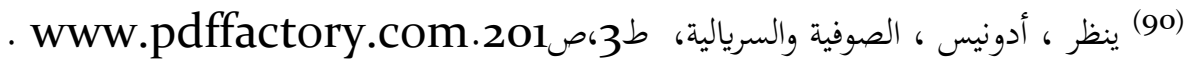

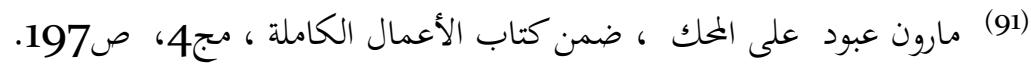

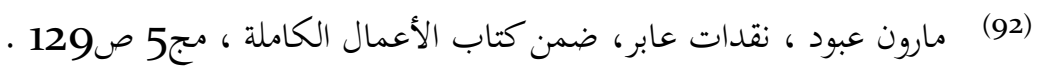

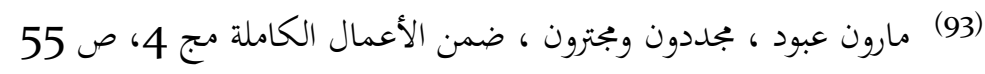

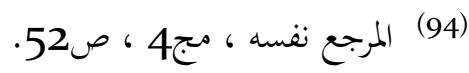

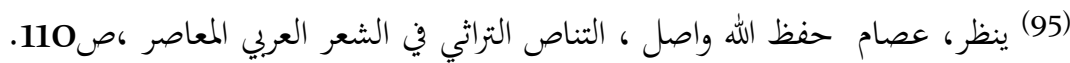

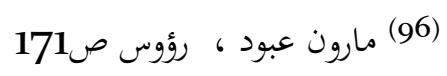

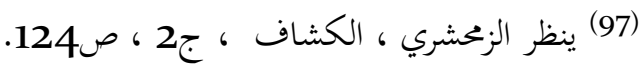

$$
\begin{aligned}
& \text { (98) ينظر المصدر نفسه ، ج5،ص } 246
\end{aligned}
$$

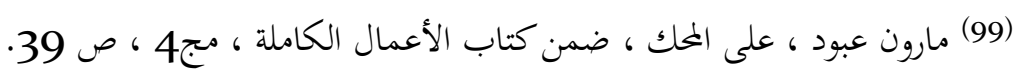

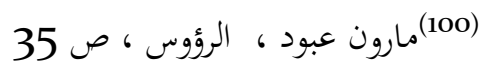

$$
\begin{aligned}
& \text { (101) المصدر نفسه ، ص362) } \\
& \text { (102) المصدر نفسه ، ص2920 }
\end{aligned}
$$

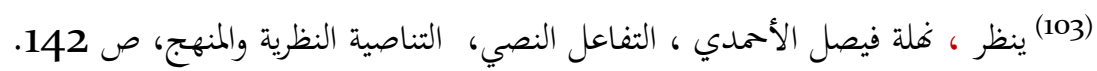

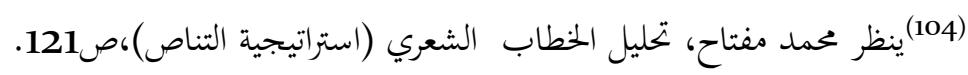

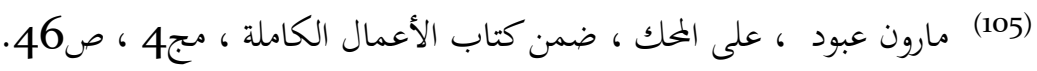

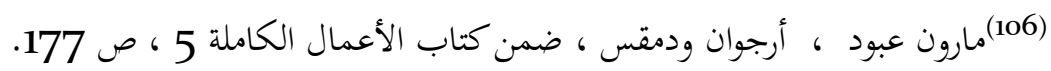

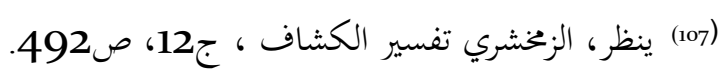

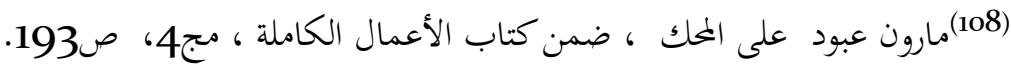

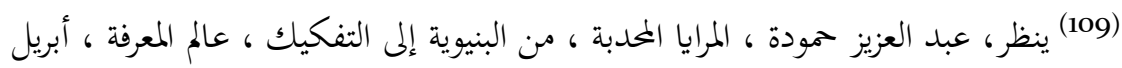




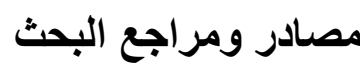

- القرآن الكريم برواية حفص عن عاصم البحم

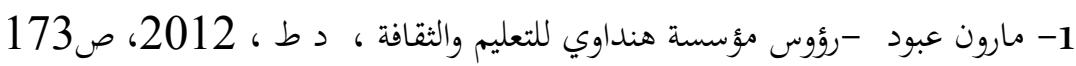

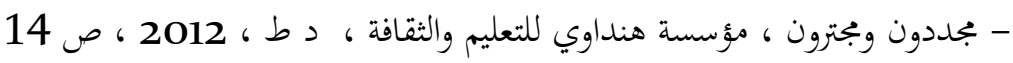

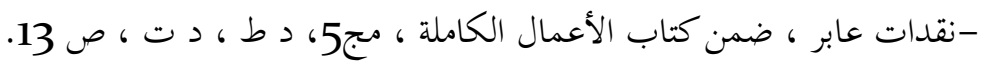

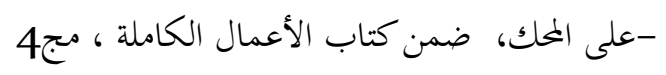

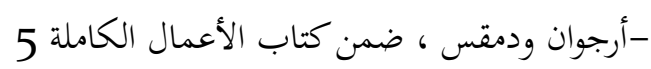

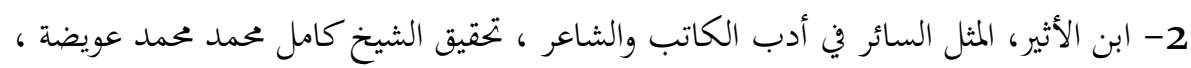
دار الكتب العلمية ، بيروت - لـبنان.

3- ابن رشيق القيرواني ، العمدة في محاسن الشعر وآدابه ونقده ، المكتبة العصرية ، صيدا- بيروت ، بلين دط، 1424هـ-2004م.

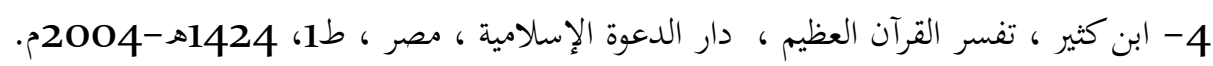

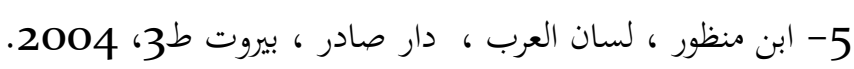

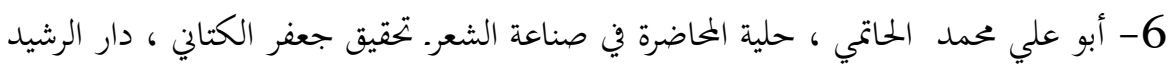

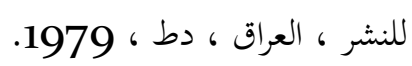

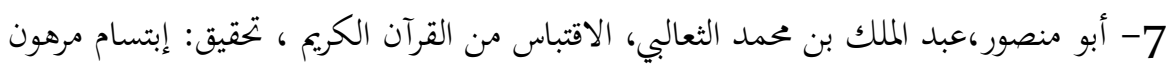

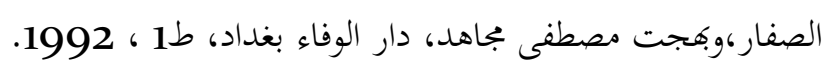

8- أممد الزعبي ، التناص نظريا وتطبيقيا، مقدمة نظرية مع دراسة تطبيقية للتناص في رواية رؤياء

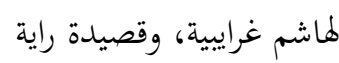

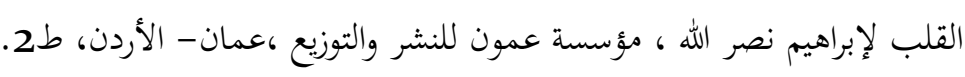

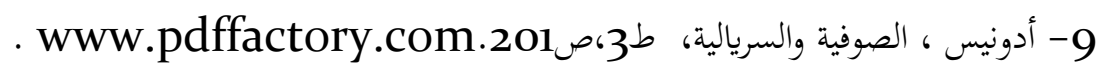

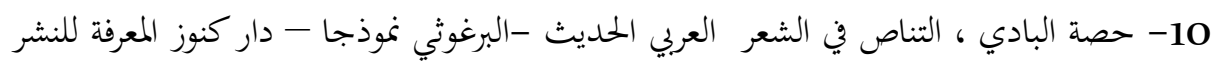

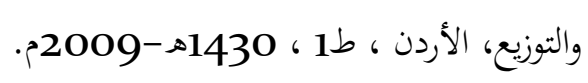

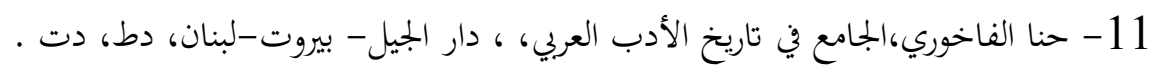

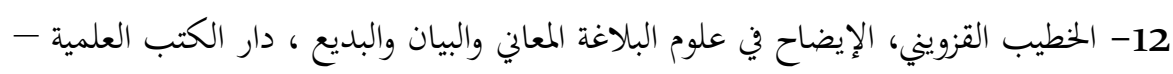

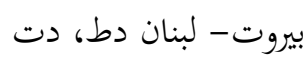
13- خليل الموسى ، قراءات في الشعر العربي المعاصر ، موقع اتحاد الكتّاب العرب على شبكة الإنترنس www.awu-dam.com

14- الزخشري ، تفسير الكشاف عن حقائق التأويل وعيون الأقاويل في وجوه التأويل دار المعرفة

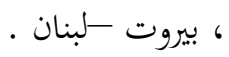


15- سعيد يقطين - انفتاح النص الروائي: النص والسياق ، المركز الثقافي العربي ، الدار البيضاء - المغرب ، ط2001، 201 201

- من النص إلى النص المترابط : مدخل إلى جماليات الإبداع التفاعلي ، المركز

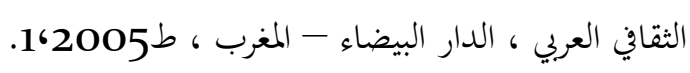

16- صبري حافظ ، أفق الخطاب النقدي ، دراسات نظرية ودراسات تطبيقية ، دار شرقيات

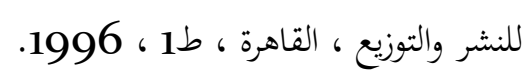
17- صلاح فضل ، بلاعة الخطاب وعلم النص ، عالم المعرفة ، سلسلة كتب ثقافية شهرية يصدرها

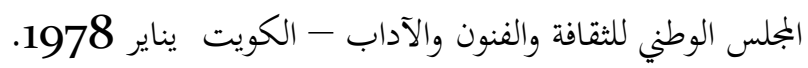
18- الطبري ، جامع البيان عن تأويل آي القرآن ، تحقيق عبد الله بن محسن التركي ، بمركز البحوث

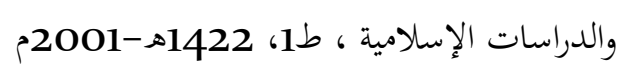
19- عبد الرزاق بلال ، جدلية التعالق النصي بين السرقات الأدبية والتناص مقاربة اصطلاحية، منشورات ما بعد الحداثة ، ط1، 2009. 20- عبد الله الغذامي ،الخطيئة والتكفير ، من البنيوية إلى التشريحية ، نظرية وتطبيق ، المركز الثقافي العربي ، الدار البيضاء -المغرب ، ط6، 2006 2006م.

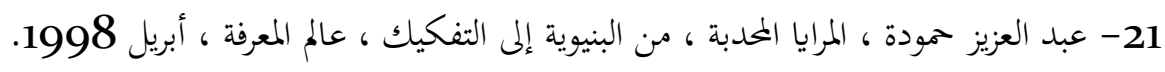

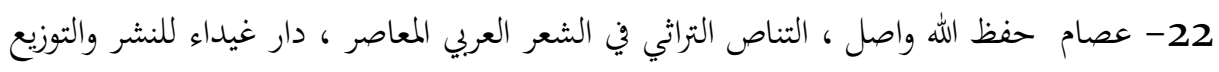

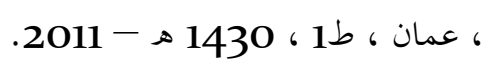

23 - محمد مندور، - في الأدب والنقد، هضة مصر للطباعة والنشر ، القاهرة -مصر، د ط ، د .

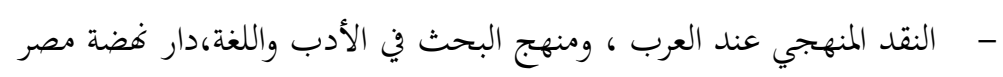

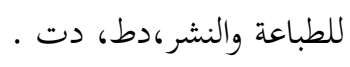

24 - محمد مفتاح ، تحليل الخطاب الشعري (استراتيجية التناص)المركز الثقافي العربي ، الدار البيضاء

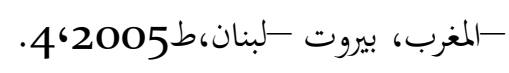

25- محمد خير البقاعي ، دراسات في النص والتناصية ، مركز الإنماء الحضاري ، حلب - سوريا ،

. 1998 ، 1 . n

26- محمد عزام ، النص الغائب ، بتليات التناص في الشعر العرب، منشورات إتحاد الكتاب العرب - L دمشق د ط، 2001.

27- نبيل منصر ، الخطاب الموازي للقصيدة العربية المعاصرة ، دار توبقال للنشر ، الدار البيضاء -

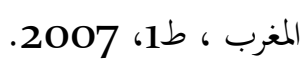




\section{المراجع المتزبمة}

1- تزيفطان تودوروف - الشعرية، ترجمة شكري المبخوت ،ورجاء بن سلامة ، دار توبقال للنشر ، الدار البيضاء - المغرب ط2، 1990.

- ميخائيل باختين ، المبدأ الحواري، ترجمة فخري صالح، المؤسسة العربية

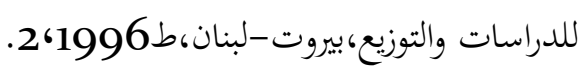

2- تيفين ساميول ، التناص ذاكرة الأدب ، ترجمة نجيب غزاوي ، منشورات اتحاد الكتاب العرب ، دمشق ، دط ، 2007.

3- - جان ايف تادييه ، النقد الأدبي في القرن العشرين ، ترجمة منذر عياشي ، مركز الإنماء الحضاري

. 1994 ،

4- جوليا كريستيفا ، علم النص ، ترجمة فريد الزاهي ، دار توبقال ، الدار البيضاء -المغرب ،

ط2، 1997.

5- رولان بارت - لذة النص، ترجمة منذر عياشي، مركز الإنماء الحضاري ، -حلب- سوريا ،

ط2، 2002.

- هسهسة اللغة، ترجمة منذر عياشي ، مركز الإنماء الحضاري -حلب- سوريا ، ط1،

.1999

6- عبد الفتاح كليطو ـ المقامات السرد والأنساق الثقافية ، ترجمة عبد الكبير الشرقاوي ، دار

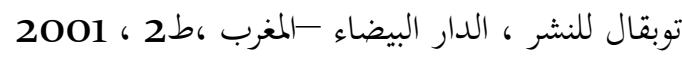

7- ميخائيل باختين ، - شعرية دوستويفسكي، تر: جميل ناصيف التركيتي، دار توبقال للنشر،

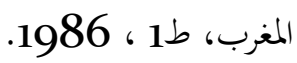

- الخطاب الروائي ، ترجمة : محمد برادة ، ط1 ،دار الفكر للدراسات و

النشر و التوزيع ، القاهرة .مصر 1987 .

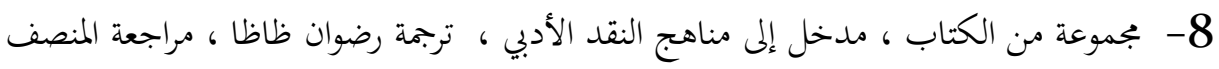

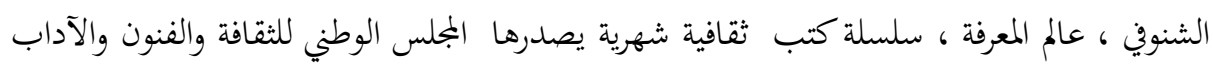

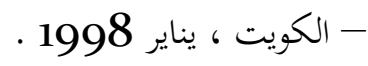

9- وليم راي ، المعنى الأدبي من الظاهراتية إلى التفكيكية ، ترجمة يونيل يوسف عزيز ، دار

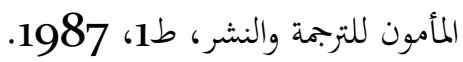

